\title{
Verification of a level-3 diesel emissions control strategy for transport refrigeration units
}

\author{
Umesh Shewalla \\ West Virginia University
}

Follow this and additional works at: https://researchrepository.wvu.edu/etd

\section{Recommended Citation}

Shewalla, Umesh, "Verification of a level-3 diesel emissions control strategy for transport refrigeration units" (2010). Graduate Theses, Dissertations, and Problem Reports. 2132.

https://researchrepository.wvu.edu/etd/2132

This Thesis is protected by copyright and/or related rights. It has been brought to you by the The Research Repository @ WVU with permission from the rights-holder(s). You are free to use this Thesis in any way that is permitted by the copyright and related rights legislation that applies to your use. For other uses you must obtain permission from the rights-holder(s) directly, unless additional rights are indicated by a Creative Commons license in the record and/ or on the work itself. This Thesis has been accepted for inclusion in WVU Graduate Theses, Dissertations, and Problem Reports collection by an authorized administrator of The Research Repository @ WVU. For more information, please contact researchrepository@mail.wvu.edu. 
Verification of a Level-3 Diesel Emissions Control Strategy for Transport Refrigeration Units Umesh Shewalla

Thesis submitted to the

College of Engineering and Mineral Resources

at West Virginia University

in partial fulfillment of the requirements

for the degree of

Master of Science

In

Mechanical Engineering

Scott W. Wayne, Ph.D., Chair

Greg Thompson, Ph.D.

Hailin Li, Ph.D.

Department of Mechanical and Aerospace Engineering

Morgantown, West Virginia

2010

Keywords: Transport Refrigeration Unit, Particulate Filter System, VDECS 


\section{ABSTRACT \\ Verification of a Level-3 Diesel Emissions Control Strategy for Transport Refrigeration Units}

\section{Umesh Shewalla}

Transport Refrigeration Units (TRUs) are refrigeration systems used to control the environment of temperature sensitive products while they are being transported from one place to another in trucks, trailers or shipping containers. The TRUs typically use an internal combustion engine to power the compressor of the refrigeration unit. In the United States TRUs are most commonly powered by diesel engines which vary from 9 to 40 horsepower. TRUs are capable of both heating and cooling. The TRU engines are relatively small, inexpensive and do not use emissions reduction techniques such as exhaust gas recirculation (EGR). A significant number of these engines operate in highly populated areas like distribution centers, truck stops, and other facilities which make them one of the potential causes for health risks to the people who live and work nearby.

Diesel particulate matter (PM) is known for its adverse effects on both human beings and the environment. Considering these effects, regulatory bodies have imposed limitations on the PM emissions from a TRU engine. The objective of this study was to measure and analyze the regulated emissions from a TRU engine under both engine out and particulate filter system out conditions during pre-durability (when the filter system was new) and post-durability test (after the filter system was subjected to 1000 hours in-field trial). The verification program was performed by the Center for Alternative Fuel, Engines and Emissions (CAFEE) at West Virginia University (WVU). In this program, a catalyzed silicon carbide (SiC) diesel particulate filter (DPF) was evaluated and verified as a Level-3 Verified Diesel Emissions Control Strategy (VDECS) ( $\geq 85 \%$ PM reduction) under California Air Resources Board (CARB) regulations $2702[1]$.

The emissions result showed that the filter system reduced diesel PM by a percentage of $96 \pm 1$ over ISO 8178-C1 [2] cycle and $92 \pm 5$ over EPA TRU [3] cycle, qualifying as a Level 3 VDECS. The percentage emission reduction in hydrocarbons (HC) and carbon monoxide (CO) was $76.8 \pm 4.8$ and 72.2 \pm 5.2 , respectively over both ISO 8178-C1 [2] and EPA TRU [3] cycles. 
It was also observed that there was $3.6 \pm 2.9$ and $7.2 \pm 3.1$ percentage reduction in oxides of nitrogen (NOx) and nitric oxide (NO), respectively with a slight increase in fuel consumption and carbon dioxide as a consequence of increased exhaust back pressure.

It is required by the CARB regulations that the diesel emissions control strategy must not increase emissions of $\mathrm{NO}_{2}$ by more than $20 \%$ by mass over the baseline value. In this study, it was observed that the total increase in $\mathrm{NO}_{2}$ level was $5.6 \pm 2.6$ percent, well within the limit specified by the CARB. 


\section{ACKNOWLEDGEMENTS}

My graduate career has been an educating and joyful journey. My education consisted of my graduate courses, research and my internship with Cummins Inc. The joyful experience was attributed to those great times with my friends and unlimited cricket in Morgantown. It is now time to acknowledge all of the individuals and sources that have been a crucial influence throughout my graduate career.

I start by thanking my parents for providing me with outstanding support both financially and mentally, specially my mother. Thank you for your cooking lessons over the phone. Special thanks to my brother Mahendra Shewalla for tolerating my inconsistency and guiding me in every aspect of life; also thanks to my little sister Mrudula Shewalla for her support.

I sincerely thank Dr. Scott Wayne for being my advisor and being there for me whenever I needed to improvise on my thought-process. Thank you for imparting the knowledge and sharing the experience. I also thank my committee members, Drs. Greg Thompson and Hailin Li for their valuable technical support and influence throughout my graduate career. To Dr. Gregory Thompson, thank you for teaching me and being there to answer every question related to engines and emissions. Your inclination towards perfection thrills me. To Dr. Hailin Li, thank you for the knowledge you have given me in your class. You have been more like a friend to me.

My friends, Chandana Nannapaneni, Pratyusha Chavali and Vijaya Gowri Kotikalapudi have been an inspiration and motivation throughout.. Also I would like to thank Vijay Yalamanchi, Sumanth, Rishi, Preethi and Praveen for being great friends. Thank you Jairo Sandoval for helping me with calculations. To Dr. Andrew Nix and Dr. Benjamin Shade, thank you for being there whenever I needed a friend and a supervisor. Thanks to Dr. Shirish Shimpi from Cummins Inc., for being my mentor.

And finally I would like to thank the CAFEE crew at the West Virginia University especially Bradley Ralston for his technical support and teaching me the essentials. I have had a sweet experience working with you all and thanks again for making my work interesting. 


\section{TABLE OF CONTENTS}

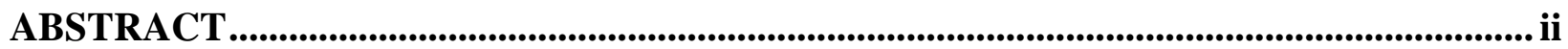

ACKNOWLEDGEMENTS ..................................................................................................... iv

TABLE OF CONTENTS ............................................................................................................................ v

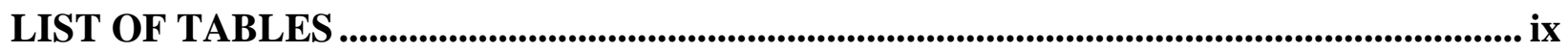

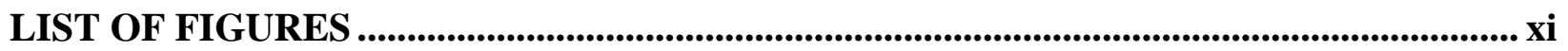

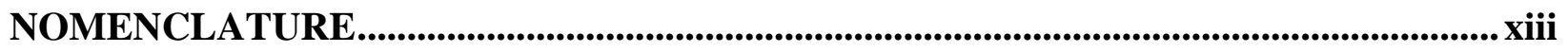

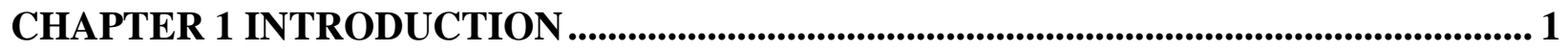

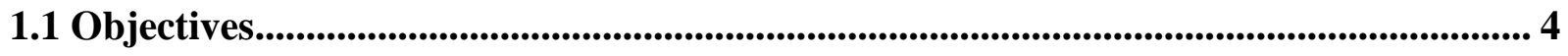

CHAPTER 2 REVIEW OF LITERATURE ........................................................................ 5

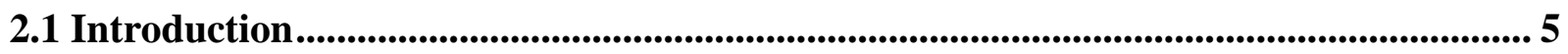

2.2 Alternative Technologies ...............................................................................................................6 6

2.3 Auxiliary Power Units ................................................................................................. 8

2.4 Regulation of Emissions ................................................................................................................. 9

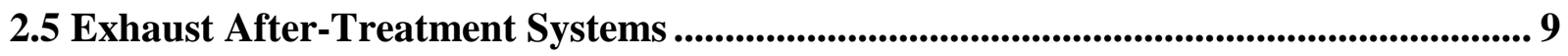

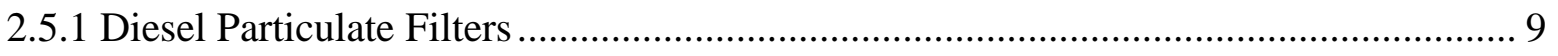

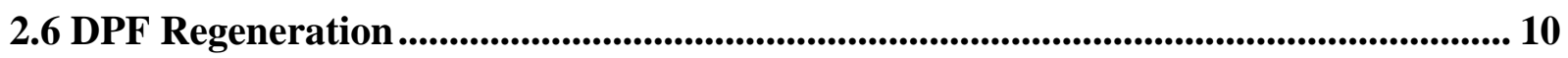

2.6.1 Effects of High Sulfur Content in the Fuel ........................................................ 11

2.6.2 Effects of Biodiesel Fuel on DPF Performance ............................................... 11

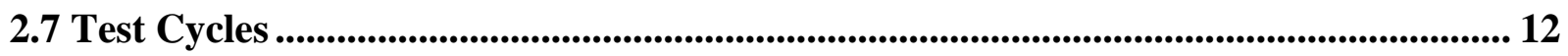

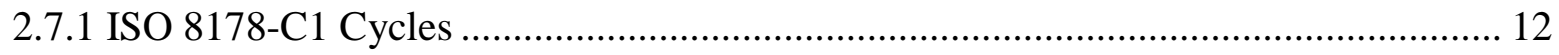

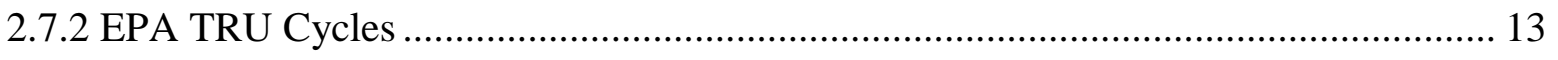

2.8 Diesel Exhaust Constituents and Their Effects ..................................................... 13

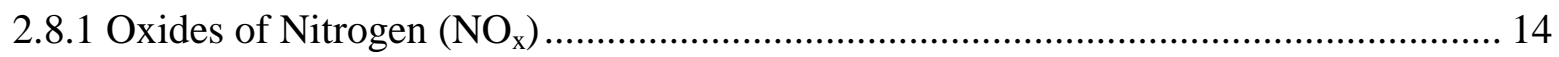

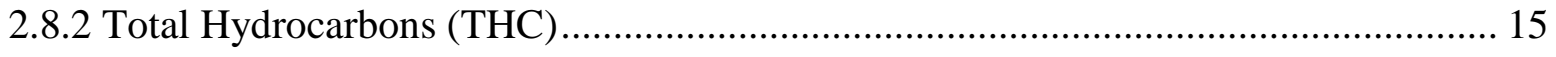

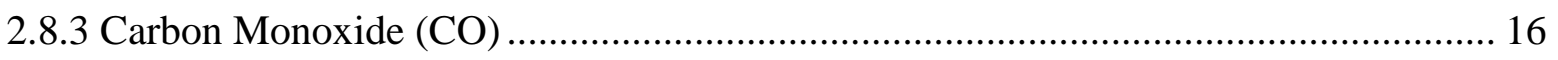

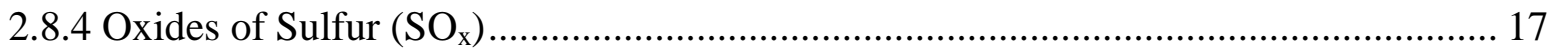

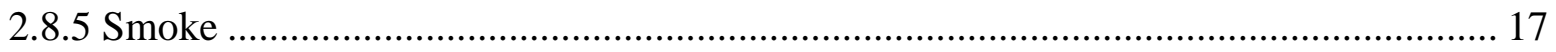




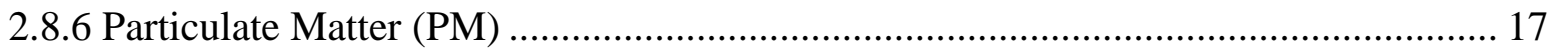

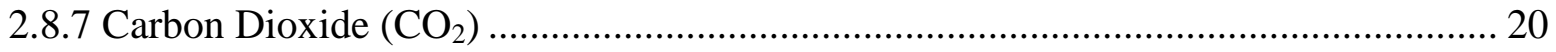

CHAPTER 3 FILTER SYSTEM AND EXPERIMENTAL EQUIPMENT............................ 21

3.1. Filter System............................................................................................................................ 21

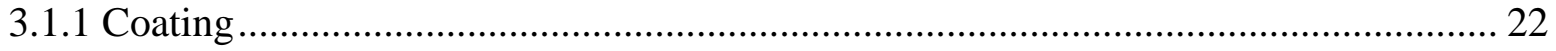

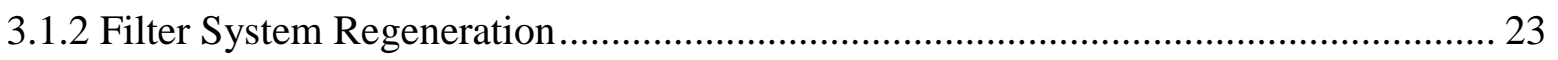

3.2 Test Engine .......................................................................................................................................... 25

3.3 Exhaust Sampling Setup ........................................................................................................... 25

3.4 Filter System De-greening ........................................................................................................... 28

3.4.1 Full-flow Exhaust Dilution Tunnel.......................................................................... 28

3.4.2 Critical Flow Venturi ....................................................................................... 29

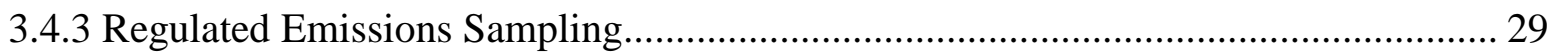

3.4.4 Particulate Sampling System and Secondary Dilution ................................................. 30

3.4.5 Filter Weighing Room and PM Filter Handling ………………………………..... 31

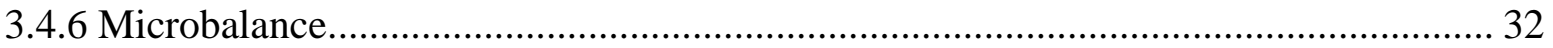

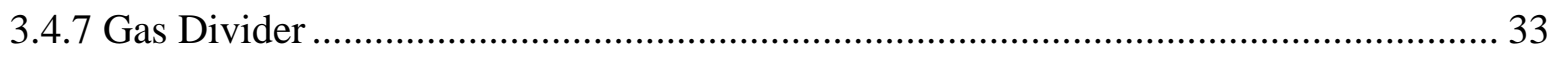

3.4.8 Exhaust Sample Gas Analyzers …………………............................................ 34

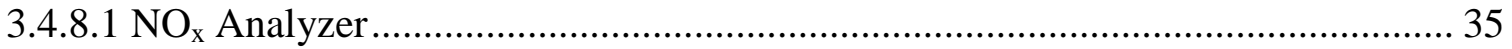

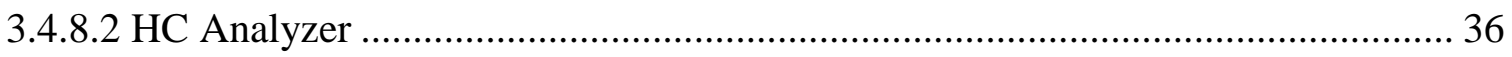

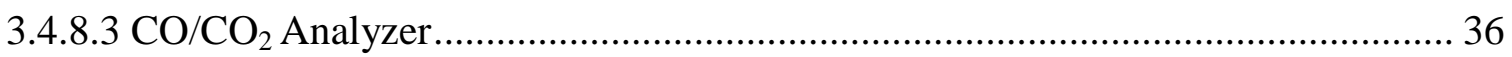

3.4.8.4 Bag Sampling ................................................................................................ 37

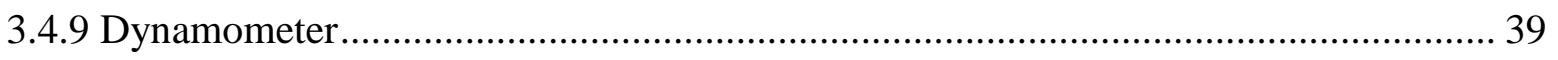

CHAPTER 4 TESTING RESULTS ........................................................................... 41

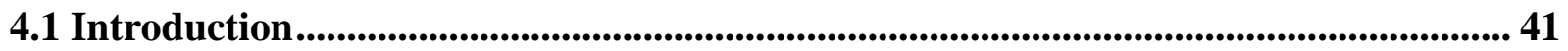

4.1.1 Pre and Post Filter Exhaust Temperatures …………….............................................. 41

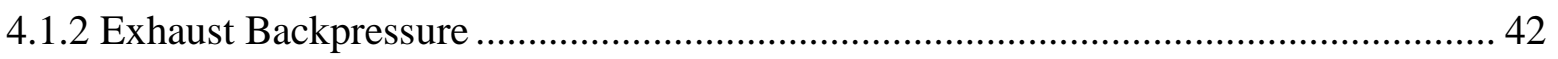

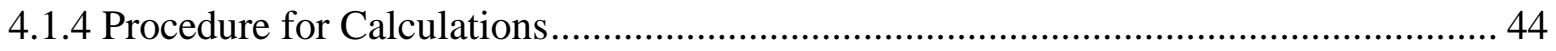

4.1.5 Procedure for 95\% Confidence Interval Calculation: ................................................. 45

4.2 Pre-Durability Emission Testing ................................................................................................. 46

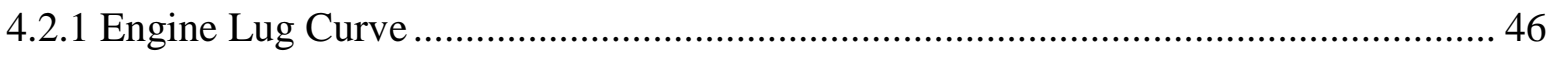

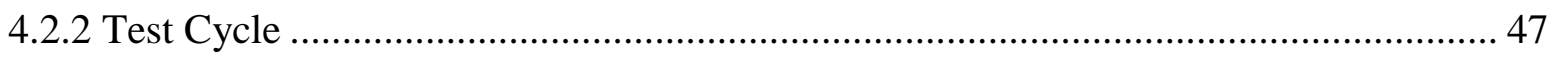




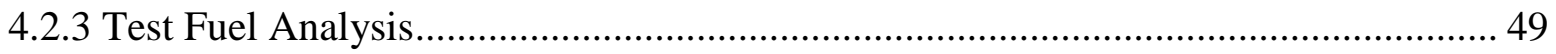

4.2.4 $\mathrm{NO}_{\mathrm{x}}$ Analyzer Correlation Test.................................................................................. 50

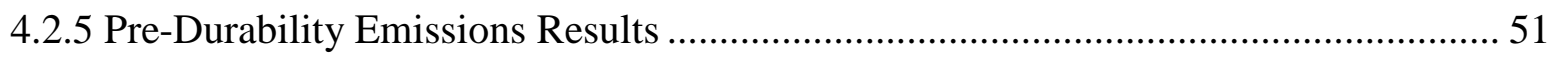

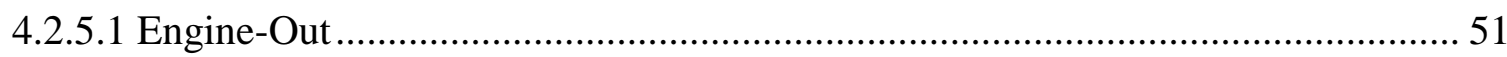

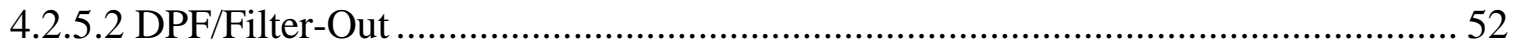

4.2.5.3 Compliance with $\mathrm{NO}_{2}$ Emission Limits ......................................................... 54

4.2.5.4 Exhaust Backpressure and Temperatures During The Test Cycle........................ 56

4.3 Post-Durability Emissions Testing ........................................................................................... 58

4.3.1 Compliance with 30\% Increase in Initial Exhaust Backpressure ................................ 58

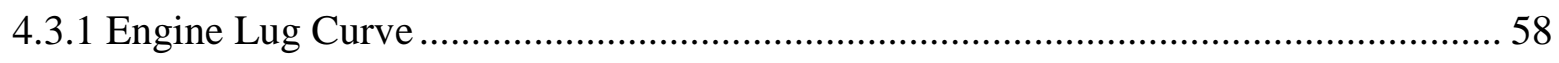

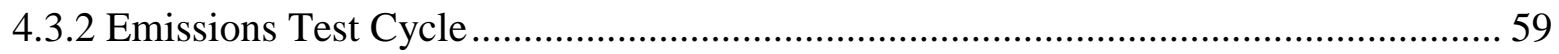

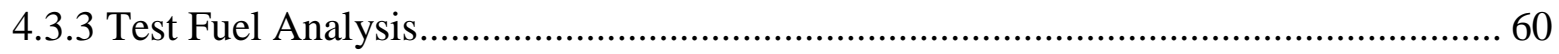

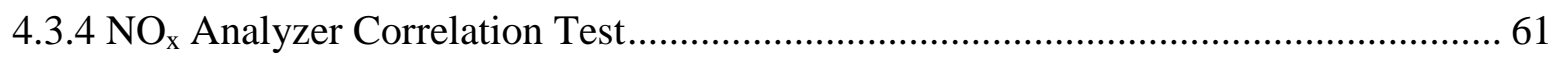

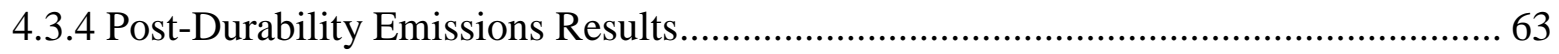

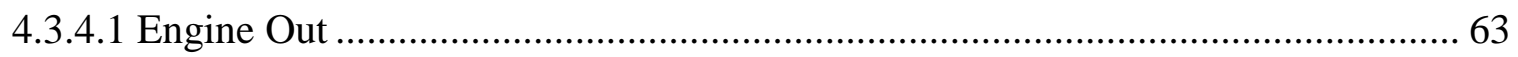

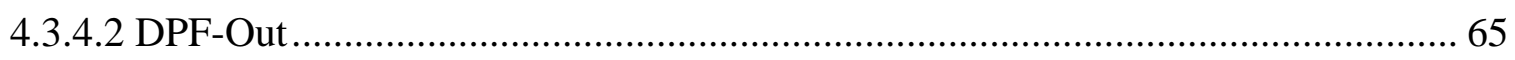

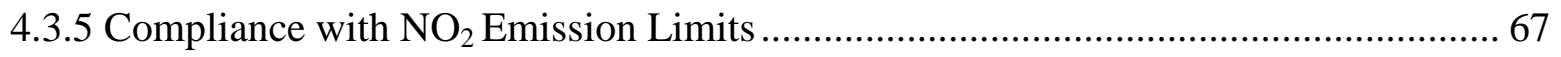

4.4 Results and Discussion....................................................................................................................... 68

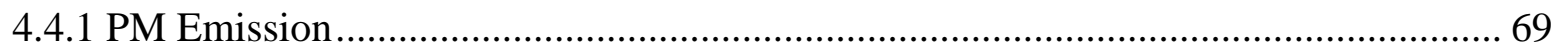

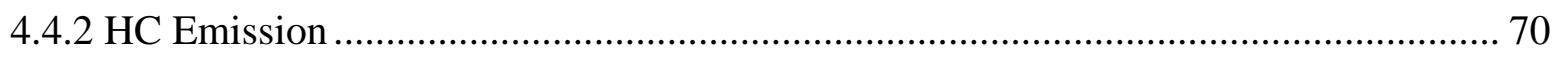

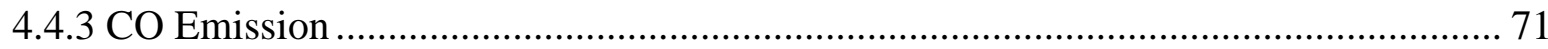

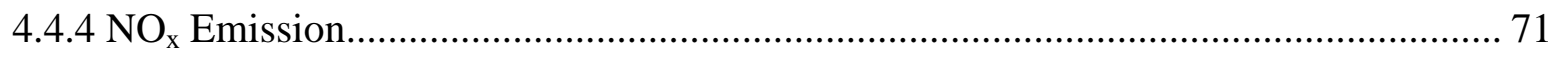

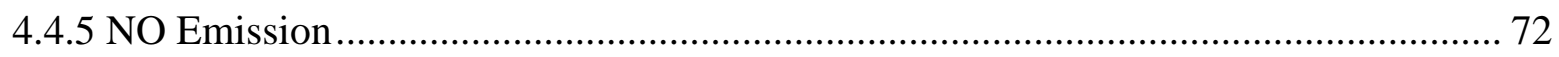

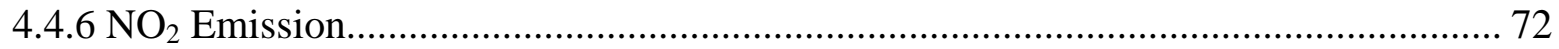

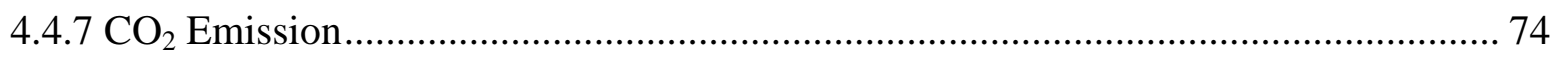

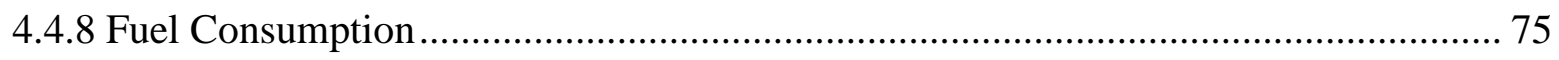

4.4.9 Final Emissions Reduction from the Filter System …………….............................. 76

4.4.10 Final Incremental Increase in $\mathrm{NO}_{2}$ Emissions ........................................................ 76

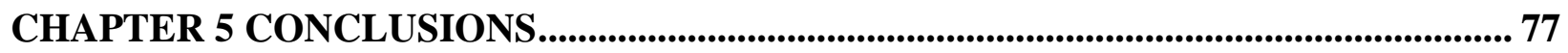

REFERENCES............................................................................................................................................ 79 


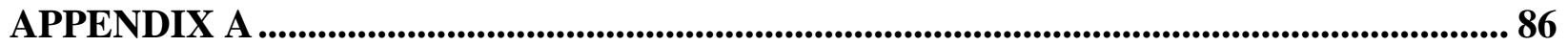

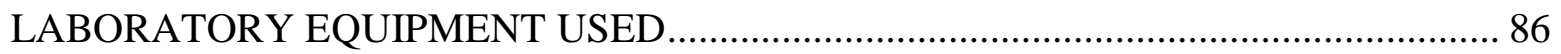

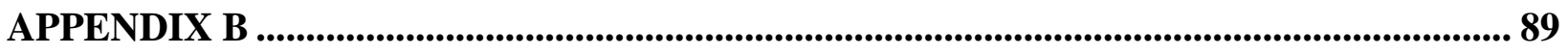

MATLAB CODE FOR CALCULATING FINAL INCREASE IN NO 2 EMISSIONS ........ 89 


\section{LIST OF TABLES}

Table 1: In-Use Performance Standards for California [7] .................................................... 3

Table 2: Regulated Emissions Sampled ............................................................................ 4

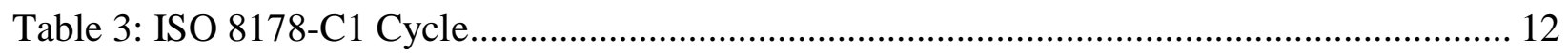

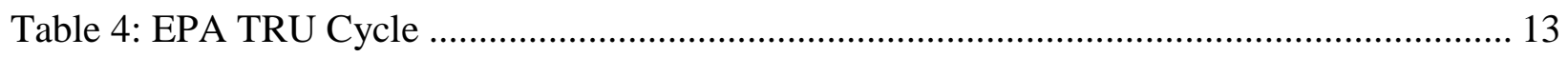

Table 5: Filter System Specifications .............................................................................. 21

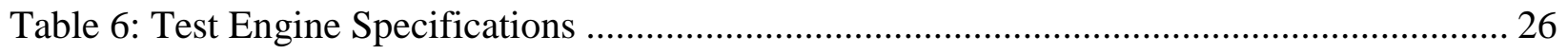

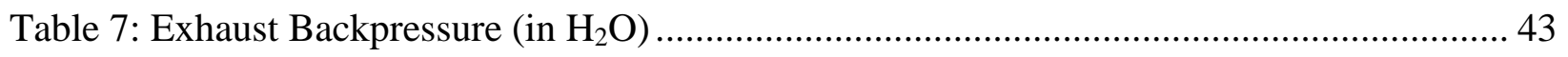

Table 8: ISO 8178-C1 Test Cycle with Performance Specifications ........................................ 48

Table 9: EPA TRU Test Cycle with Performance Specifications .......................................... 48

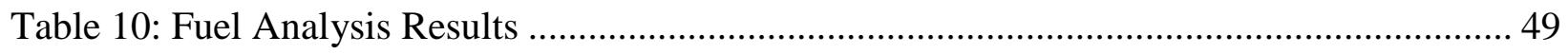

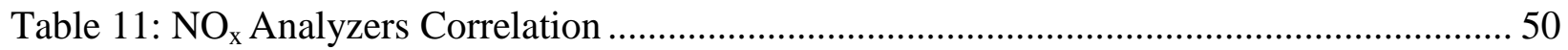

Table 12: Engine-out Weighted Brake Specific Emissions on the ISO 8178-C1 Cycle ............. 51

Table 13: Comparison between EPA Tier 1 Standards for Non-Road Diesel Engines and Engine-

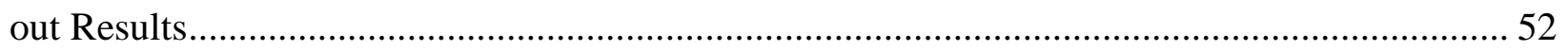

Table 14: Engine-out Weighted Brake Specific Emissions on EPA TRU cycle ....................... 52

Table 15: DPF-out Weighted Brake Specific Emissions on the ISO 8178-C1 Cycle ................. 53

Table 16: Comparison between EPA Tier 1 Standards for Non-Road Diesel Engines and DPF-

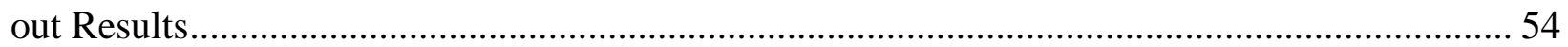

Table 17: DPF-out Weighted Brake Specific Emissions on the EPA TRU Cycle ..................... 54

Table 18: Pre and Post-Durability Exhaust Backpressures...................................................... 58

Table 19: ISO 8178-C1 Test Cycle with Performance Specifications for Post-Durability Testing

Table 20: EPA TRU Test Cycle with Performance Specifications for Post-Durability Testing .. 60

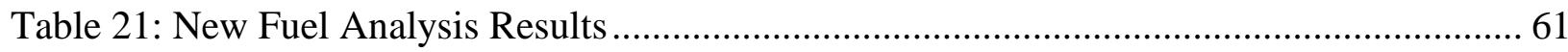

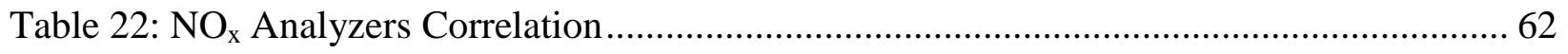

Table 23: Baseline Weighted Brake Specific Emissions on ISO 8178-C1 Cycle ..................... 64

Table 24: EPA Tier 1 Emissions Standard for Non-Road Diesel Engines ................................. 64

Table 25: Baseline Weighted Brake Specific Emissions on the EPA TRU Test Cycle .............. 65 
Table 26: DPF-out Weighted Brake Specific Emissions on the ISO 8178-C1 Cycle ................. 66

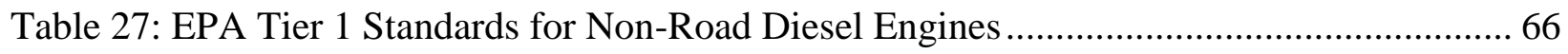

Table 28: DPF-out Weighted Brake Specific Emissions on the EPA TRU Test Cycle .............. 67

Table 29: Final Percentage Emissions Reduction.................................................................. 76

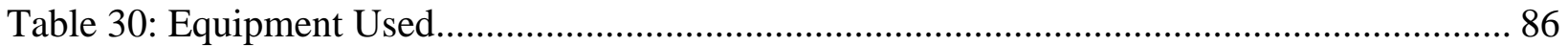




\section{LIST OF FIGURES}

Figure 1: Transport Refrigeration Unit on a Trailer [4] ................................................... 1

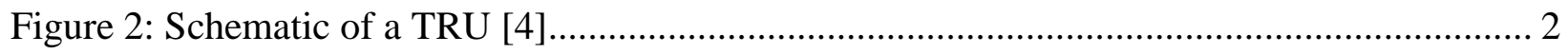

Figure 3: Block Diagram of a Refrigeration Cycle [8] .................................................... 5

Figure 4: Diesel Particle Size and Mass Distribution, With Respiratory Deposition Curve [31] 19

Figure 5: Filter System Used For Testing [38] ................................................................. 22

Figure 6: Exhaust Temperature Profiles of Typical TRU Load Cycles [39]............................ 24

Figure 7: Schematic of Exhaust Sampling System [40] .................................................... 27

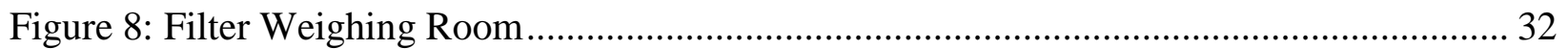

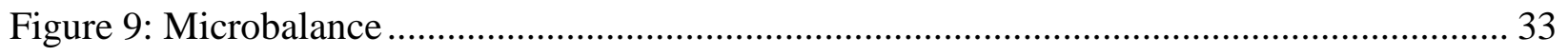

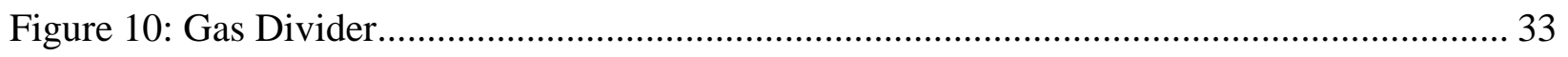

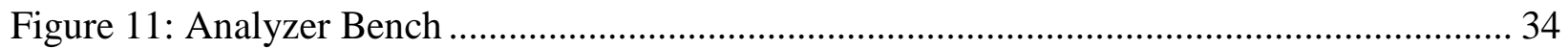

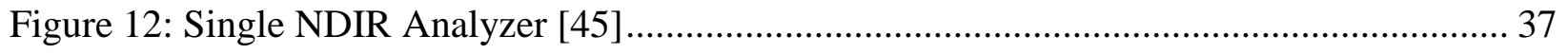

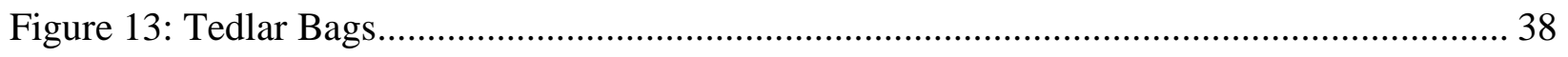

Figure 14: Air-cooled Eddy Current Dynamometer ............................................................... 39

Figure 15: Dyne Systems Co. DTC-1 Digital Throttle Controller.......................................... 40

Figure 16: Pre and Post-filter Exhaust Gas Temperature .................................................... 42

Figure 17: Exhaust Backpressure (in $\mathrm{H}_{2} \mathrm{O}$ ) Recorded During the Last Three Repeat Runs of EPA

TRU 4 Mode Cycles for Preconditioning the Filter System ................................................. 43

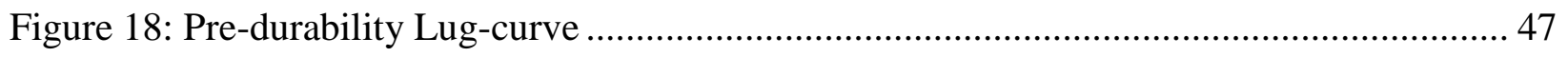

Figure 19: Continuous Data Demonstration for $\mathrm{NO}_{\mathrm{x}}$ Analyzer Correlation............................... 50

Figure 20: Average Exhaust Backpressure Measured During Baseline Testing ....................... 56

Figure 21: Average Exhaust Backpressure Measured During DPF-out Testing ....................... 57

Figure 22: Average Exhaust Pre and Post-filter Temperatures ............................................. 57

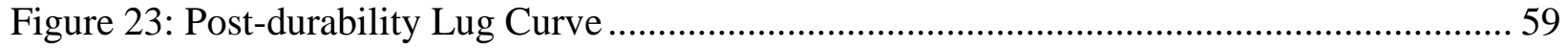

Figure 24: Continuous Data Demonstration for $\mathrm{NO}_{\mathrm{x}}$ Analyzer Correlation (both in $\mathrm{NO}_{\mathrm{x}}$ mode) 62

Figure 25: Continuous Data Demonstration for $\mathrm{NO}_{\mathrm{x}}$ Analyzer Correlation (both in NO mode) 63

Figure 26: Weighted Brake Specific Particulate Matter (g/bhp-hr)....................................... 69

Figure 27: Weighted Brake Specific Hydrocarbons (g/bhp-hr) ........................................... 70

Figure 28: Weighted Brake Specific Carbon Monoxide (g/bhp-hr) ...................................... 71 
Figure 29: Weighted Brake Specific Nitrogen Oxides (g/bhp-hr) ....................................... 72

Figure 30: Weighted Brake Specific Nitrogen Monoxide (g/bhp-hr) .................................... 73

Figure 31: Weighted Brake Specific Nitrogen Dioxide (g/bhp-hr) ..................................... 73

Figure 32: Weighted Brake Specific Carbon Dioxide (g/bhp-hr) ........................................ 74

Figure 33: Weighted Brake Specific Fuel Consumption (lb/bhp-hr)................................... 75 


\section{NOMENCLATURE}

$\mathrm{AC}=$ Alternating Current

ATCM = Airborne Toxic Control Measure

CAFEE $=$ Center for Alternative Fuels, Engines and Emissions

CARB = California Air Resources Board

CFR = Code of Federal Regulations

$\mathrm{CO}=$ Carbon Monoxide

$\mathrm{CO}_{2}=$ Carbon Dioxide

CVS = Constant Volume Sampler

DC = Direct Current

DOE $\quad=$ Department of Energy

EPA = Environmental Protection Agency

FTP = Federal Test Procedure

$\mathrm{HC}=$ Hydrocarbon

HFID = Heated Flame Ionization Detector

$\mathrm{g} / \mathrm{bhp}-\mathrm{hr} \quad=$ Grams per Brake Horse Power-Hour

IC = Internal Combustion

ISO = International Organization for Standardization

$\mathrm{MPH}=$ Miles per Hour

NDIR = Non-Dispersive Infrared Analyzers

$\mathrm{NO}_{2} \quad=$ Nitrogen Dioxide

NO $=$ Nitrogen Monoxide

$\mathrm{NO}_{\mathrm{x}} \quad=$ Nitrogen Oxides

NRTC = Non Road Transient Cycle

$\mathrm{PM}=$ Particulate Matter

TAC $=$ Toxic Air Contaminant

THC = Total Hydrocarbons

TRU = Transport Refrigeration Unit

VDECS = Verified Diesel Emissions Control Strategy

WV = West Virginia 


\section{CHAPTER 1}

\section{INTRODUCTION}

Trucks and trailers are used to ship food and other perishable goods because it is a low cost and reliable means of transportation. Large refrigeration units/transport refrigeration units (TRUs) as shown in Figure 1 are used to keep perishable goods from spoiling while being shipped from one place to another. To run the compressor of these refrigeration units, the refrigerators typically use nine to forty horsepower diesel engines. Hence the TRU diesel engine is independent of the vehicle's propulsion system. The load in the refrigerated space is very sensitive to the temperature fluctuations and maintaining the desired temperature is very important.

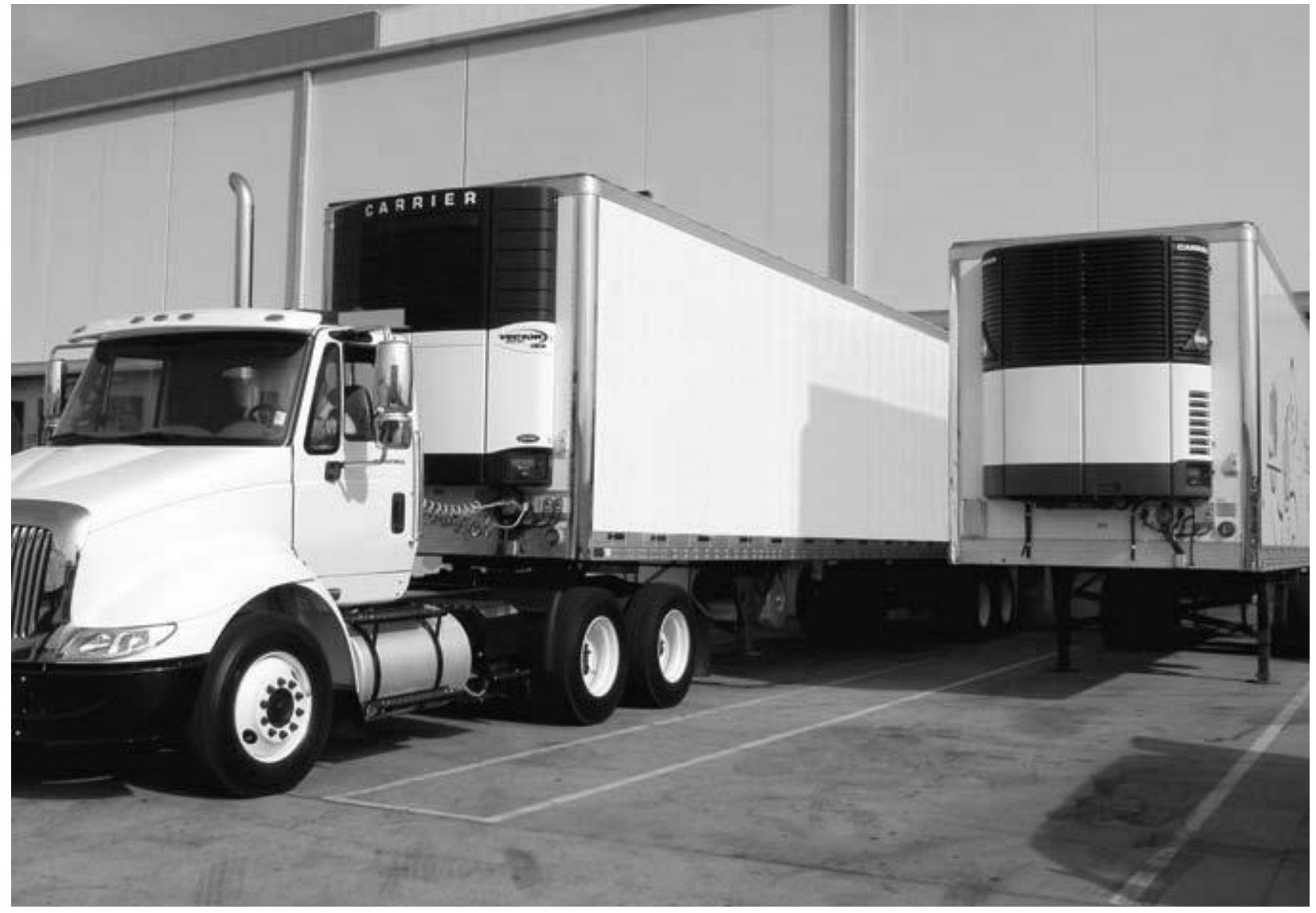

Figure 1: Transport Refrigeration Unit on a Trailer [4] 


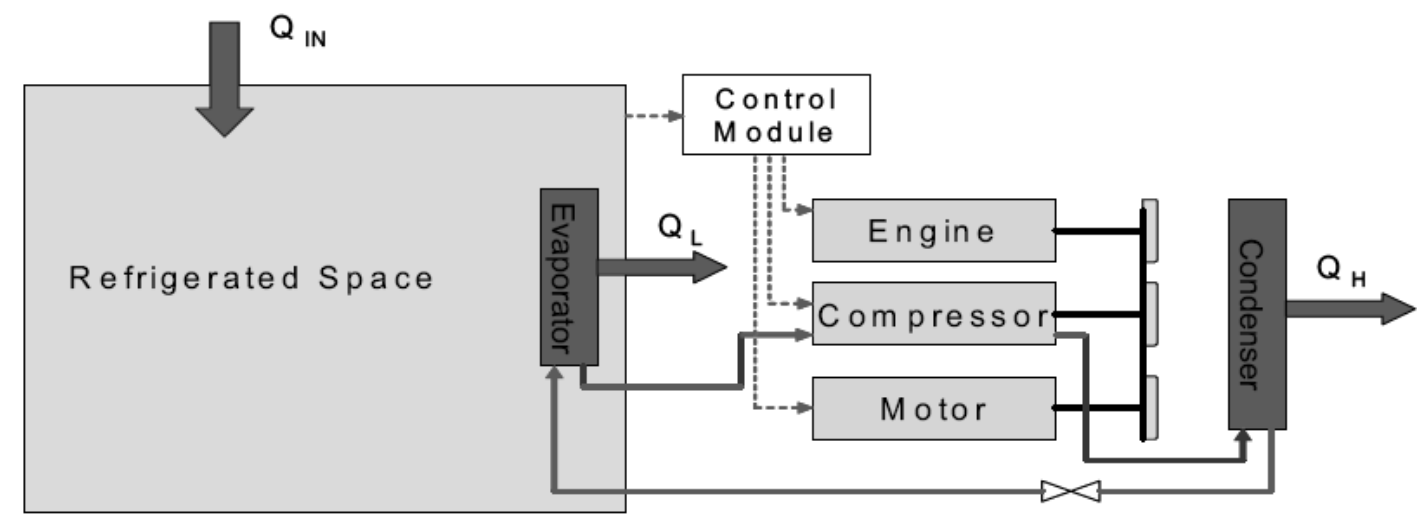

Figure 2: Schematic of a TRU [4]

As shown in Figure 2, a typical TRU consists of a power unit (diesel engine), a refrigerant compressor, a throttling valve, an evaporator, a condenser, fans and a climate controller. The cooling capacity is regulated by the control module and thermostatic on/off control is used to maintain the trailer temperature.

Diesel engines are known for their efficiency but at the same time are controlled by several government agencies for high emission levels. TRU/TRU generator sets have always been exempt from the stringent anti-idling regulations imposed considering the total loss incurred if the goods being carried are spoiled. California was the first state to express their interest in reducing the PM emissions from TRU engines as they can create a dangerous environment to the people working at the warehouse facility. This scrutiny by the California Air Resources Board (CARB) brought about innovative ideas that lead to less polluting and more efficient exhaust after-treatment systems for TRUs.

The test engine used for this study was removed from an in-service TRU and was mounted on a test stand and coupled to a Mustang air-cooled eddy current dynamometer. The particulate filter system was tested following the steady-state test procedure outlined in the CARB off-road regulations (13 CCR § 2423) and the incorporated California Exhaust Emission Standards and Test Procedures for New 2000 and Later Off-Road Compression-Ignition Engines [5]. Three repetitions for both pre-durability and post-durability baseline engine-out emissions and diesel particulate filter (DPF) out emissions were measured over the 8-mode International Organization for Standardization (ISO) 8178-C1 [2] and Environmental Protection Agency Transport 
Refrigeration Unit (EPA TRU) [3] cycle. The test systems used for this study complied with Title 40 CFR Part 89-control of emissions from new and in-use non-road compression-ignition engines [6]. The engine was operated for the prescribed time in each mode, completing engine speed and load changes in the first 20 seconds.

As shown in Table 1, in-use performance standards for TRU and TRU generator sets demand that PM emissions must be less than $0.02 \mathrm{~g} / \mathrm{bhp}$-hr for engines with $\geq 25$ horsepower (hp) to qualify under ultra-low emission performance standard [7].

Table 1: In-Use Performance Standards for California [7]

\begin{tabular}{|c|c|c|}
\hline Brake Horsepower Category & $\begin{array}{l}\text { PM } \\
\text { Standard } \\
\text { (g/bhp- } \\
\text { hr) }\end{array}$ & $\begin{array}{l}\text { Options for Meeting } \\
\text { Performance Standard }\end{array}$ \\
\hline \multicolumn{3}{|c|}{ Low Emission Performance Standards } \\
\hline$<25 \mathrm{hp}$ & 0.30 & $\begin{aligned} &> \text { Use an engine that } \\
& \text { meets the Engine } \\
& \text { Certification Value } \\
&>\text { Retrofit with at least } \\
& \text { Level } 2 \text { DECS } \\
&(>50 \% \text { PM10 } \\
& \text { reduction) } \\
&>\text { Use an Alternative } \\
& \text { Technology }\end{aligned}$ \\
\hline$\geq 25 \mathrm{hp}$ & 0.22 & $\begin{aligned}> & \text { Use an engine that } \\
\text { meets the Engine } & \text { Certification Value } \\
> & \text { Retrofit with at least } \\
& \text { Level } 2 \text { DECS } \\
> & \text { Use an Alternative } \\
& \text { Technology }\end{aligned}$ \\
\hline \multicolumn{3}{|c|}{ Ultra-Low Emission Performance Standard } \\
\hline$<25 \mathrm{hp}$ & N/A & $\begin{aligned} &> \text { Retrofit with Level } 3 \\
& \text { DECS (>85 \% PM10 } \\
& \text { reduction) } \\
&>\text { Use an Alternative } \\
& \text { Technology }\end{aligned}$ \\
\hline$\geq 25 \mathrm{hp}$ & 0.02 & $\begin{aligned} &> \text { Use an engine that } \\
& \text { meets the Engine } \\
& \text { Certification Value } \\
&>\text { Retrofit with Level } 3 \\
& \text { DECS }\end{aligned}$ \\
\hline
\end{tabular}


The particulate filter system tested in this program was designed to achieve ultra-low emission performance standards for $\geq 25 \mathrm{hp}$ engines.

\subsection{Objectives}

The global objective of this study was to present and evaluate the emissions performance of passive catalyzed DPFs and certify the exhaust after-treatment system as a Level 3 Verified Diesel Emissions Control Strategy (VDECS) under CARB Regulation 2702 [1] by quantization of PM emissions reduction from the TRU engine by $\geq 85 \%$. The study was conducted at the Engines and Emissions Research Laboratory at West Virginia University on a model year 1999 Kubota v2203-DI-E engine. This engine was removed from an in-service TRU and was shipped to WVU. Pertinent details of the test engine have been discussed in the later chapters. The emissions from the test engines were collected over the ISO 8178-C1 [2] cycle and EPA TRU [3] cycle. Table 2 lists the exhaust species measured.

Table 2: Regulated Emissions Sampled

\begin{tabular}{|l|}
\hline Hydrocarbons $(\mathrm{HC})$ \\
\hline Carbon monoxide $(\mathrm{CO})$ \\
\hline Total particulate matter $(\mathrm{TPM})$ \\
\hline Oxides of nitrogen $\left(\mathrm{NO}_{\mathrm{x}}\right)$ \\
\hline
\end{tabular}




\section{CHAPTER 2}

\section{REVIEW OF LITERATURE}

\subsection{Introduction}

The high fuel economy and torque output of diesel engines has created a positive impact in their global applications. TRUs are used for keeping fresh and frozen goods from spoiling while being transported from one place to another. For many years TRUs have been driven by diesel engines. Maintaining a refrigerated load at its required temperature is very crucial. If the load is spoiled, losses can equate to millions of dollars annually. For the same reason, TRU engines have always been exempted from the stringent anti-idling regulations imposed by government on the diesel engines. In addition, operation of TRU engines is very noisy which can be of concern in populated areas especially when the deliveries occur during late evening and early morning hours [8]. Figure 3 illustrates a typical refrigeration cycle.

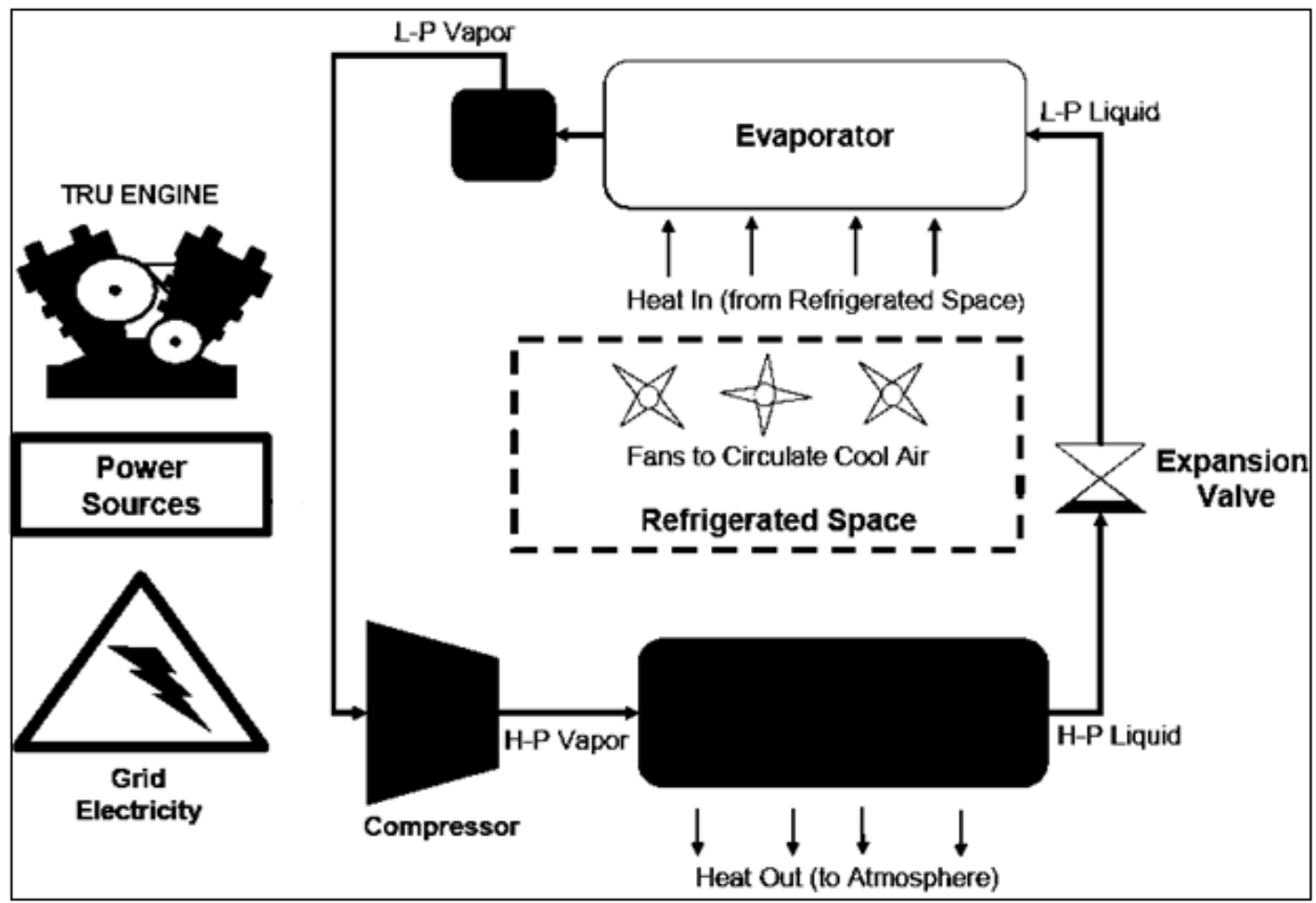

Figure 3: Block Diagram of a Refrigeration Cycle [8] 
A number of these TRUs operate in highly populated places like distribution centers and truck stops; creating a possible hazardous environment for those who work and live nearby. It has been reported that TRU engines produced 2 tons of diesel PM and 20 tons of $\mathrm{NO}_{\mathrm{x}}$ every day in 2000 [7]. Considering the adverse effects of diesel emissions on human beings and the environment, CARB identified diesel PM as a toxic air contaminant in 1998, a diesel risk reduction plan was approved by CARB in 2000 and an airborne toxic control measure (ATCM) was introduced [7].

Implementation of the ATCM has forced TRU owners to achieve surplus emissions reductions by installing cleaner certified engines with verified retrofit emission control strategies and by using alternative technologies. As a result, diesel PM emissions from TRUs are expected to decrease to 1.6 tons a day by 2010 and 0.3 tons a day by 2020 [7]. Alternative technologies are an approach to address the growing concerns over the TRU engine emissions and noise pollution.

\subsection{Alternative Technologies}

Alternative technologies such as electric standby, cryogenic temperature control systems or hybrid cryogenic temperature control systems, alternative fueled engines, exclusive alternative diesel fuels that have been verified as a VDECS and fuel cell-powered temperature control systems can be used to meet the Low Emissions Transport Refrigeration Units (LETRU) and Ultra Low Emissions Transport Refrigeration Units (ULETRU) in-use performance standards [9].

1) Electric standby: A TRU engine is used with an electric motor which drives the refrigeration system when it is at a distribution center. This combination is required to produce zero TRU engine emissions with very few exceptions such as during an emergency.

2) Cryogenic temperature control systems or hybrid cryogenic temperature control systems: Cryogenic temperature control systems uses liquid carbon dioxide or liquid nitrogen (cryogen) that is routed through an evaporator coil that cools air blown over the coil. A propane-fired heater is used to superheat the carbon dioxide for heating and defrosting and a vapor motor drives the fan and alternator. Electrically driven fans may be used 
instead of a vapor motor and heating and defrost needs may be met by using electric heaters and/or vehicle engine coolant. Cryogenic temperature control systems have no diesel engine driving a refrigeration system.

Hybrid cryogenic temperature control systems use a cryogenic temperature control system in combination with a conventional TRU that is powered by a TRU engine. These systems would comply with the TRU ATCM only if they produce zero TRU engine emissions at the distributions centers.

3) Alternative fueled engines: Alternative fueled engines uses natural gas, propane, ethanol, or methanol. Alternative fueled engines do not rely on diesel fuel, except as a pilot ignition source at an average ratio of less than 1 part diesel fuel to 10 parts total fuel on an energy equivalent basis.

Spark-ignited engines using alternative fuel (> $25 \mathrm{hp}$ ) must meet the large spark-ignited engine standards. Alternative fueled compression-ignition engine retrofit systems (e.g. dual-fueled pilot-injection kits) must be verified under the Verification Procedure, Warranty and In-Use Compliance Requirements for In-Use Strategies to Control Emissions from Diesel Engines [1].

4) Exclusive alternative diesel-fuel: Alternative diesel-fuel should be verified as a VDECS by Air Resources Board (ARB). Gas-to-liquid (GTL) synthetic fuel can be used as alternative diesel fuels. PM emissions have been shown to be reduced in on-road engines with GTL diesel fuel without increase in any of the regulated emissions component [10, $11,12]$.

5) Fuel cell-powered temperature control systems: emissions must be verified and evaluated though the Verification Procedure Warranty and In-Use Compliance Requirements for In-Use Strategies to Control Emissions from Diesel Engines [1].

The performance of TRUs was analyzed with diesel engines and alternate power systems. The fuel cell hybrid model was coupled to the TRU thermal model and it was observed 
that the energy efficiency was improved; also, the fuel cell hybrid system reduced the emissions and noise considerably. But fuel cells face cost, reliability and hydrogen infrastructure issues which limit their usage in the local markets [13].

\subsection{Auxiliary Power Units}

An auxiliary power unit (APU) is equipped onto a large ground vehicle to provide the energy required to drive any mechanism other than propulsion. A small diesel engine can be used as an APU on commercial trucks to the power cooling system, heating system, generators, and air conditioning compressor. An independent APU along with a fuel tank can be used to refrigerate food transported in the TRUs, semi trailers, and train cars without the use of an external power supply.

The federal Department of Transportation regulations in United States requires 10 hours of rest for the driver for every 11 hours of driving. While the driver is taking rest, the engines are often run in idle mode for air conditioning, heating or light. Although diesel engines are considered to be very efficient in idle mode, it is still costly to idle the engine for a long period of time considering the fuel used and engine wear. An APU is very efficient in overcoming the long idles as the APU's generator requires just a fraction of fuel used by the main engine. Also, during the idling period the generator can be used to power the main engine block and fuel system heaters so that the main engine can be started easily when ready for departure. Hence, APUs can be considered as an idling reduction technology which could help eliminate 11 million tons of carbon dioxide emissions from truck fleet idling in United States each year [14].

In-field testing was done to demonstrate the use of a fuel cell APU as a power source for a TRU. A fuel cell unit consisting of a fuel cell, $\mathrm{H}_{2}$ fuel storage, DC/DC converter, batteries and an inverter was connected to a TRU. It was observed that undersized fuel cells can be used for large power applications, also the efficiency of the cooling process can be increased by powering the compressor of the refrigeration unit by DC motors [15]. 


\subsection{Regulation of Emissions}

The CARB identified diesel PM as a toxic air contaminant in 1998 and a diesel risk reduction plan was approved by ARB in 2000. To control emissions from TRU sets, CARB approved an airborne toxic control measure (ATCM) on February 26, 2004 for in-use diesel fueled TRUs [7]. The purpose of the ATCM is to protect public health by reducing the PM emissions from diesel engines. The ATCM is expected to reduce overall diesel PM in 2020 by $80 \%$ compared to the 2002 baseline emissions [7].

\subsection{Exhaust After-Treatment Systems}

\subsubsection{Diesel Particulate Filters}

A Diesel Particulate Filter (DPF) is a system that relies on complex chemical reactions designed to eliminate the particulate matter or soot (solid particles) from the exhaust stream of diesel engines. A DPF cleans the exhaust by forcing the exhaust gases to flow through the filter where the PM is trapped onto the filter. Most DPFs are designed and built considering the filtration, minimum pressure drop, durability, and cost. Different types of DPF include cordierite wall flow, silicon carbide wall flow, ceramic fiber, and paper filters.

Cordierite filters are the most common filters in the market made of ceramic material. Cordierite filter cores have alternate channels plugged. The exhaust gas is forced to flow through these alternate channels and the particulates are collected on the inner surface. The advantages of cordierite filters are that they have excellent thermal properties, filtration efficiency and are inexpensive compared to other filter types. The main drawback with the cordierite substrate is its low melting point temperature with a possibility to melt down during filter regeneration especially active regeneration where the filter is heated to high temperatures to oxidize the particulates.

Silicon carbide, or $\mathrm{SiC}$ is the most popular filter material after cordierite. It also works on the principle that the exhaust gas flows through the alternate channel wall and the particulate matter is trapped on the inlet face. The main advantage of SiC filter is its high melting point and it is suitable for both active and passive regeneration. The main drawback of the $\mathrm{SiC}$ filter is that it is not thermally stable. 
Ceramic fiber filters are porous filters formed by mixing various types of ceramic fibers. The filter efficiency can be controlled by varying the porosity. The main advantage of ceramic fiber filters is that they produce lower back pressure compared to wall flow filters. A metal fiber flow filter is also available which allows an electric current to pass through the monolith to heat the core for regeneration purposes, allowing the filter to regenerate at low exhaust temperatures.

Paper filters are used as disposable filters without regeneration. They are used in coal mines and when a diesel engine is run indoors for a short period of time.

Kramer et al. [16] explained a PM-Metalit system construction solely from metal that is extremely robust against severe mechanical loads. The system utilized passive regeneration, and required significantly lower exhaust temperatures and low degree of engine control measures. This system was evaluated using a modified John Deere 4.5 L Tier 3 off-highway engine under steady-state 8-mode conditions and over the Non Road Transient Cycle (NRTC). A total PM reduction of $>80 \%$ and $>65 \%$ was observed under steady-state 8 -mode and NRTC test cycle, respectively.

\subsection{DPF Regeneration}

Regeneration is the process of removing the soot formed on the DPF by converting the soot into carbon dioxide. Regeneration is required for all DPFs for efficient functioning. Regeneration is predominantly passive or active.

DPFs are usually coated with catalytic material which helps the chemical reaction which converts soot into $\mathrm{CO}_{2}$ to occur at lower exhaust temperatures. In passive regeneration, the soot formed on the DPF is oxidized to $\mathrm{CO}_{2}$ continuously while the engine is running. The catalytic reaction takes place as a consequence of high exhaust temperatures during the normal engine cycle.

For a complete passive regeneration, engines should produce high exhaust temperatures consistently which is not possible with all engines. In engines where high exhaust temperatures are not possible, the DPF undergoes active regeneration periodically by injecting a small mist of diesel fuel. In active regeneration, a mist is injected into the exhaust stream which travels through the exhaust pipe to wet the pre-catalyst. This causes a chemical reaction which raises 
DPF temperatures to the level required to convert the soot into $\mathrm{CO}_{2}$. Active regeneration takes place when sensors on the DPF alert the engine computer that the pressure drop across the DPF is increasing and that the DPF is clogging.

Different approaches have been proposed for active regeneration of DPFs. An actively regenerating DPF was shown that applied secondary fuel injection directly within the exhaust system upstream of a diesel oxidation catalyst [17]. Lee et al. [18] proposed a plasma burner for the regeneration of an active DPF system. The ability of the plasma burner to elevate temperature of exhaust gas, high combustion efficiency, robust flame stability in dynamic load conditions was successfully confirmed.

\subsubsection{Effects of High Sulfur Content in the Fuel}

Fuel sulfur content also affects the performance of passive DPFs. The Department of Energy (DOE) conducted a study examining the effects of sulfur on diesel particulate filters on a catalyzed DPF and continuously regenerating DPF [19]. DOE found that DPFs cease to reduce PM emissions with fuels containing $150 \mathrm{ppm}$ sulfur and become a source of PM emissions with 350 ppm sulfur fuels. Overall, baseline PM emissions increased as the fuel sulfur level increased. At 3 ppm sulfur both devices reduced PM emissions by 95 percent, and at $30 \mathrm{ppm}$ sulfur the PM reduction efficiencies of both devices dropped to the around 72 percent.

\subsubsection{Effects of Biodiesel Fuel on DPF Performance}

The impacts of $100 \%$ biodiesel on a DPF were studied by Tschoke et al. [20] in 2002. It was shown that the soot loading speed was reduced due to lower particulate emissions without any significant effect on passive regeneration. It was also explained that the active regeneration efficiency improved for a given temperature, and lower temperature was needed to initiate regeneration with soot emitted from biodiesel. It was explained by Boehman et al. [21] that B20 fuel generates less ordered and tight soot nanostructure, which improves its reactivity to react at a lower temperature than PM from conventional fuel. Similarly Vertin et al. [22] explained that the DPFs tested with biodiesel (B20) had higher regeneration efficiency than ULSD fuel, without considerable change in pressure drop and filtration efficiency. 


\subsection{Test Cycles}

The filter system in this study was tested following the steady-state procedure outlined in the CARB off-road regulations (13 CCR $\S 2423$ ) and the incorporated California Exhaust Emission Standards and Test Procedures for New 2000 and Later Off-Road Compression-Ignition Engines, Part 1-B [5]. CARB required that the result be provided for the 8-mode ISO 8178-C1 cycle [2] and the 4-mode EPA TRU Cycle (40 CFR Part 1039 § 1039.645) [3]. The ISO 8178-C1 [2] and EPA TRU [3] cycles are described in the subsequent sections.

\subsubsection{ISO 8178-C1 Cycles}

The ISO 8178 is an international standard designed for emissions certification and equivalent approvals for non-road engines in many countries worldwide. The ISO 8178 is comprised of many steady-state test cycles (designated as C1, C2, D1, D2, E1, F, G1 etc.) which have been designed for various kinds of engines and their applications. $\mathrm{C} 1$ and $\mathrm{C} 2$ type cycles are used for off-road vehicles; D1 and D2 for constant speed; F type for locomotives; G1, G2 and G3 for utility, lawn and garden; and E type for marine applications. Each of these cycles consists of several modes with different weighting factors [2].

CARB off-road regulations (13 CCR $\S 2423)$ [5] requires that the diesel emissions control strategy be tested on ISO 8178-C1 [2] test cycles. In this program, the TRU engine and the filter system were tested on the 8-mode ISO 8178-C1 [2] cycle with corresponding weighting factor as shown in Table 3.

Table 3: ISO 8178-C1 Cycle

\begin{tabular}{|c|c|c|c|c|c|c|c|c|}
\hline Mode & 1 & 2 & 3 & 4 & 5 & 6 & 7 & 8 \\
\hline Weighting Factor & 0.15 & 0.15 & 0.15 & 0.10 & 0.10 & 0.10 & 0.10 & 0.15 \\
\hline Speed & \multicolumn{4}{|c|}{ Rated Speed } & \multicolumn{3}{|c|}{ Intermediate Speed } & Idle \\
\hline Torque $(\%)$ & 100 & 75 & 50 & 10 & 100 & 75 & 50 & - \\
\hline
\end{tabular}




\subsubsection{EPA TRU Cycles}

The EPA TRU [3] cycle is a steady-state cycle consisting of four modes extracted from the ISO 8178-C1 [2] cycle with different weighting factors (each mode with a weighting factor of 0.25 ). Mode 1 of the EPA TRU cycle corresponds with mode 2 of the ISO 8178-C1 (rated speed, 75\% load), mode 2 with mode 3 (rated speed, 50\% load), mode 3 with mode 6 (intermediate speed, 75\% load), and mode 4 with mode 7 (intermediate speed, 50\% load). An EPA TRU cycle has been shown in Table 4.

Table 4: EPA TRU Cycle

\begin{tabular}{|c|c|c|c|c|}
\hline Mode & 1 & 2 & 3 & 4 \\
\hline Weighting Factor & 0.25 & 0.25 & 0.25 & 0.25 \\
\hline Speed & \multicolumn{2}{|c|}{ Rated Speed } & \multicolumn{2}{|c|}{ Intermediate Speed } \\
\hline Torque (\%) & 75 & 50 & 75 & 50 \\
\hline
\end{tabular}

\subsection{Diesel Exhaust Constituents and Their Effects}

The harmful emissions from diesel engines are classified into gaseous and particulate emissions. The harmful gaseous diesel engine emissions are hydrocarbons, carbon monoxide and oxides of nitrogen. The level of oxides of nitrogen is much higher in diesel engines than that of gasoline engines because diesel engines undergo lean combustion.

The unique part of diesel engine emissions is the particulates which are visible in engine exhaust and consist of submicron-size carbon particles which adsorb unburned fuel and engine lubricants. The particles agglomerate to form aggregates of various dimensions. Most of the diesel particulates are small enough to be inhaled with significant effects on the respiratory tissues [23].

Emissions characterization and reduction are required for improved combustion and performance. Also, emissions from the engines have to be reduced so that the engines can meet the standards set by government regulations like the EPA and CARB. 


\section{Diesel Fuel Combustion Reaction:}

The products of combustion of a diesel fuel under stoichiometric actual conditions (equivalence ratio $=1$ ) are carbon dioxide, water vapor and some oxides of nitrogen. But practically, the combustion process in diesel engines is lean and much more complex under high pressure and high temperatures. The main diesel combustion reaction has been given below and the combustion products have been discussed:

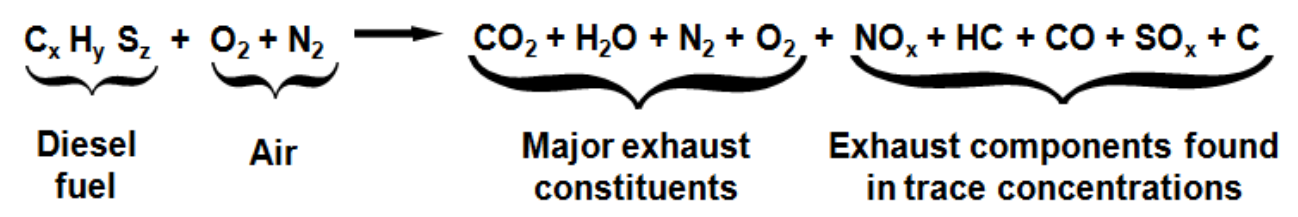

(Equation 1)

Of these products of combustion, $\mathrm{CO}, \mathrm{NO}_{\mathrm{x}}, \mathrm{PM}$, and $\mathrm{HC}$ have an adverse effect on the environment which forced the EPA to regulate the levels of these emissions. Oxides of Sulfur $\left(\mathrm{SO}_{\mathrm{x}}\right)$ also effects both humans and environment adversely but can be controlled by limiting the sulfur content in the fuel.

\subsubsection{Oxides of Nitrogen $\left(\mathrm{NO}_{\mathrm{x}}\right)$}

Oxides of nitrogen are formed as a result of the reaction between nitrogen $\left(\mathrm{N}_{2}\right)$ and oxygen $\left(\mathrm{O}_{2}\right)$ at high temperature and pressure such as that seen in the combustion reaction. $\mathrm{NO}_{\mathrm{x}}$ is a composition of several different gaseous compounds of nitrogen and oxygen. The reactions representing the formation of $\mathrm{NO}_{\mathrm{x}}$ are known as the Zeldovic mechanism [24].

$$
\begin{aligned}
& \mathrm{O}_{2}+\mathrm{N}_{2} \leftrightarrow \mathrm{NO}+\mathrm{N} \\
& N+\mathrm{O}_{2} \leftrightarrow \mathrm{NO}+\mathrm{O}
\end{aligned}
$$

The reactions given by the Zeldovic mechanism shown above are the main reactions involved in the formation of $\mathrm{NO}_{\mathrm{x}}$. It is highly dependent on temperature, flame speed and residence time of exhaust gas in the combustion chamber. Most of the $\mathrm{NO}_{\mathrm{x}}$ formation occurs during the diffusion burn phase of the combustion process. This phase is known for its very lean local air-fuel ratio and high in-cylinder temperatures [25].

For regulatory purposes, $\mathrm{NO}$ and $\mathrm{NO}_{2}$ are usually grouped together as $\mathrm{NO}_{\mathrm{x}}$ emissions with $\mathrm{NO}$ being the predominant oxide of nitrogen produced inside the cylinder and $\mathrm{NO}_{2}$ being 10 to 20 
percent of $\mathrm{NO}_{\mathrm{x}}$. Relatively high $\mathrm{NO}$ is obtained for lean and stoichiometric mixtures whereas relatively low yields are found for rich mixtures. Diesel engines have high $\mathrm{NO}_{\mathrm{x}}$ levels as they operate at very lean conditions. There has always been a trade-off between the $\mathrm{NO}_{\mathrm{x}}$ production rate and the PM production rate. Any modifications made to the engine in terms of combustion to reduce the $\mathrm{NO}_{\mathrm{x}}$ production rate would increase the PM production rate and vice versa.

\section{Effects of $\mathrm{NO}_{x}$}

$\mathrm{NO}_{\mathrm{x}}$ constituents are lung irritants and can increase pulmonary infections and vulnerability to respiratory illness in human beings. $\mathrm{NO}_{\mathrm{x}}$ is the number one contributor to ground level ozone also known as smog. Smog is a result of unburnt $\mathrm{HC}$ and $\mathrm{NO}_{\mathrm{x}}$. Ground smog is an air pollution produced when sunlight causes hydrocarbons and oxides of nitrogen from automotive emissions to combine in a photochemical reaction. Smog inhalation severely irritates the mucus membrane of the nose and throat, which can lead to excessive coughing and choking. Smog also damages the normal function of the lungs and continual exposure may cause permanent damage. Smog also damages paint and building materials as a result of acid rain.

\subsubsection{Total Hydrocarbons (THC)}

Total Hydrocarbon (THC) is the collective name for several different compounds made up of carbon (C) and hydrogen (H). THC emissions are a direct consequence of incomplete combustion of the hydrocarbon fuels. The presence of lubrication oil in the combustion chamber is also a main source for the THC emission. The fuel hydrocarbons are characterized by shorter carbon chains while the lubricating oil hydrocarbons account for the heavier species. The hydrocarbon emission depends on various factors such as injection timing, injection pressure, engine load, fuel-air ratio, fuel used and engine design.

Fuel-air ratio of the combustion cycle is one of the main factors driving the THC emission. High THC emissions are observed with rich fuel mixture due to the absence of an adequate amount of oxygen for oxidizing excess fuel. THC emission is dominant during cold start of the engine in both diesel and spark ignited engines.

It was shown that a significant portion of the total pollutants emitted to the atmosphere by motor vehicles occurs immediately following the start-up of the engine when the engine block and 
exhaust manifold are cold, and the catalytic converter has not yet reached high conversion efficiencies. A strategy for dealing with cold start hydrocarbons using carbon-free hydrocarbon traps and heat exchange related Three-Way Conversion (TWC) catalyst beds were tested on a wide variety of model vehicles. It was shown that $70 \%$ of the tailpipe $\mathrm{HC}$ emissions from the motor vehicles were during the cold start of the engine [26].

Diesel exhaust hydrocarbons are in the gas phase, and are adsorbed on the diesel particulates. Several species are present in both the vapor and on the particle. Virtually all compounds which are regarded as volatile have a vapor pressure above $0.1 \mathrm{~mm} \mathrm{Hg}$ at standard conditions $\left(20^{\circ} \mathrm{C}, 1\right.$ atm). Volatile diesel hydrocarbons typically contain aliphatic and aromatic molecules with up to 24 carbon atoms in the molecule. The particulate phase hydrocarbons are measured by dissolving the particulate in an organic solvent. The soluble organic fraction (SOF) is the measure of volatile hydrocarbon adsorbed on the insoluble carbonaceous diesel soot particulate [27].

\section{Effects of THC}

In the atmosphere, hydrocarbons undergo photochemical reactions leading to the formation of ground level ozone and photochemical smog. Smog is formed as a result of HC compounds and oxides of nitrogen in the presence of sunlight.

\subsubsection{Carbon Monoxide (CO)}

Carbon monoxide is a colorless, odorless and poisonous gas. Carbon monoxide is formed during the intermediate combustion stages of hydrocarbon fuels. The presence of a lower amount of air compared to the amount of fuel present reduces the formation of $\mathrm{CO}_{2}$ from $\mathrm{CO}$ [27]. Low gas temperatures, short residence times or a high fuel/air ratio at the combustion site may result in incomplete combustion and CO emissions. Diesel engines typically have low CO emissions due to their lean combustion process. However in advanced diesel engine technology, fuel rich zones may be created within the cylinder due to the absence of sufficient in cylinder charge motion or turbo charging. This results in localized incomplete combustion results in increased $\mathrm{CO}$ concentrations. 


\section{Effects of CO}

$\mathrm{CO}$ is an extremely poisonous gas to human life. $\mathrm{CO}$ enters the bloodstream and reduces the delivery of oxygen to the body's organs and tissues. Exposure to elevated CO levels is associated with impairment of visual perception, manual dexterity, learning ability and performance of complex tasks [27].

\subsubsection{Oxides of Sulfur $\left(\mathrm{SO}_{\mathrm{x}}\right)$}

$\mathrm{SO}_{\mathrm{x}}$ are products of oxidation of the fuel-bound sulfur during the combustion process. They react with water in the atmosphere to form sulfuric acid and contribute to acidification of soil and water. $\mathrm{SO}_{\mathrm{x}}$ can be controlled by limiting the sulfur content of the fuel.

High concentrations of $\mathrm{SO}_{\mathrm{x}}$ affect breathing and may aggravate existing respiratory and cardiovascular disease. $\mathrm{SO}_{\mathrm{x}}$ produce foliar damage on trees and agricultural crops.

\subsubsection{Smoke}

Semi-volatile and volatile particles that escape the combustion process block the passage of light through the exhaust and are responsible for black smoke. Black smoke is typically emitted during accelerations and at high loads.

White smoke is made up of particles of essentially colorless liquid (unburned hydrocarbons and water vapor) which reflect or refract light. White smoke is an issue under cold conditions at low loads [23].

\subsubsection{Particulate Matter (PM)}

Particulate matter (PM) emissions from IC engines are solid phase emission constituents. PM is formed when insufficient air or low combustion temperature prohibits complete combustion of the fuel. PM is a complex mixture of organic carbon (OC), elemental carbon (EC), metals (from fuel and engine wear), and sulfates with bound water. Many different organic pollutants are adsorbed on these particles. Diesel particulate matter (DPM) is the most unique and difficult-tocontrol emission from diesel engines. Major factors affecting the formation of PM are engine load, fuel injection and fuel characteristics. 
Particulate matter in diesel exhaust is due to rich combustion zones in the cylinder and is primarily associated with increased fueling. Particulates from the burning of engine lubricants have traditionally been a minor factor, but reduction of PM from combustion (due to improved fuel atomization and fuel injection management) is causing lubricant-source to be of greater concern. The transient power behavior in diesel engines is particularly troubling because rapid rise in engine power demand usually causes "puff" of PM and produces CO as the turbocharger accelerates. The highest particulate concentrations in direct-injection diesel engines are found in the core region of each fuel spray where local equivalence ratios are very rich [28].

The nature and quantity of PM would greatly vary with sampling method. For consistency of measurement, regulations have defined the method of sampling PM so as to try and quantify every form of PM. DPM is sampled by filtering of diluted exhaust at temperatures not higher than $125^{\circ} \mathrm{F}\left(52^{\circ} \mathrm{C}\right)$. This collection method stimulates the conditions under which diesel particulates are released from vehicles into the atmosphere. The regulated particulates correspond to diesel soot which is suspended in our ambient air.

As the exhaust is mixed with air in the dilution tunnel and the gas temperature decreases, the volatile hydrocarbons condense or adsorb on the surface of the carbon nuclei and sulfuric acid molecules combine with water forming hydrated sulfuric acid (sulfate) particles. Small particles cluster into larger, agglomerated particles. Sampling filters capture the solid particles as well as liquid droplets from the gas.

Hydrocarbons adsorbed on the surface of carbon particles forms soluble organic fraction (SOF) of the particulates. The soluble organic fraction of PM contains most of the polycyclic aromatic hydrocarbon (PAHs) and nitro-PAHs emitted with diesel exhaust gases. In wet exhaust, the organic fraction constitutes over $50 \%$ of the total particulates, where $30 \%$ can be attributed to lube oil hydrocarbons and $20 \%$ to fuel-derived hydrocarbons [27].

\section{Ultrafine Nanoparticles}

Ultrafine nanoparticles are a result of reducing the mass of PM from diesel engines by adapting engine control strategies and after-treatment devices [29]. Ultrafine nanoparticles are defined as those which are below 100nm in their aerodynamic diameter. There are two sizes of particulate 
matter that have been rated as $\mathrm{PM}_{10}$, the larger of the two and $\mathrm{PM}_{2.5} \cdot \mathrm{PM}_{10}$ covers all particles at and under 10 microns and $\mathrm{PM}_{2.5}$ covers all particles at and under 2.5 microns. Ultrafine nanoparticles are further classified into nucleation mode and accumulation mode particles. Nucleation mode particles include all the particles which are $<30 \mathrm{~nm}$ in size and accumulation mode particles includes all the particles in the size range of $50 \mathrm{~nm}$ and $300 \mathrm{~nm}$ [30]. The mass and particle size distribution of diesel exhaust with the respiratory deposition regions have been shown in Figure 4.

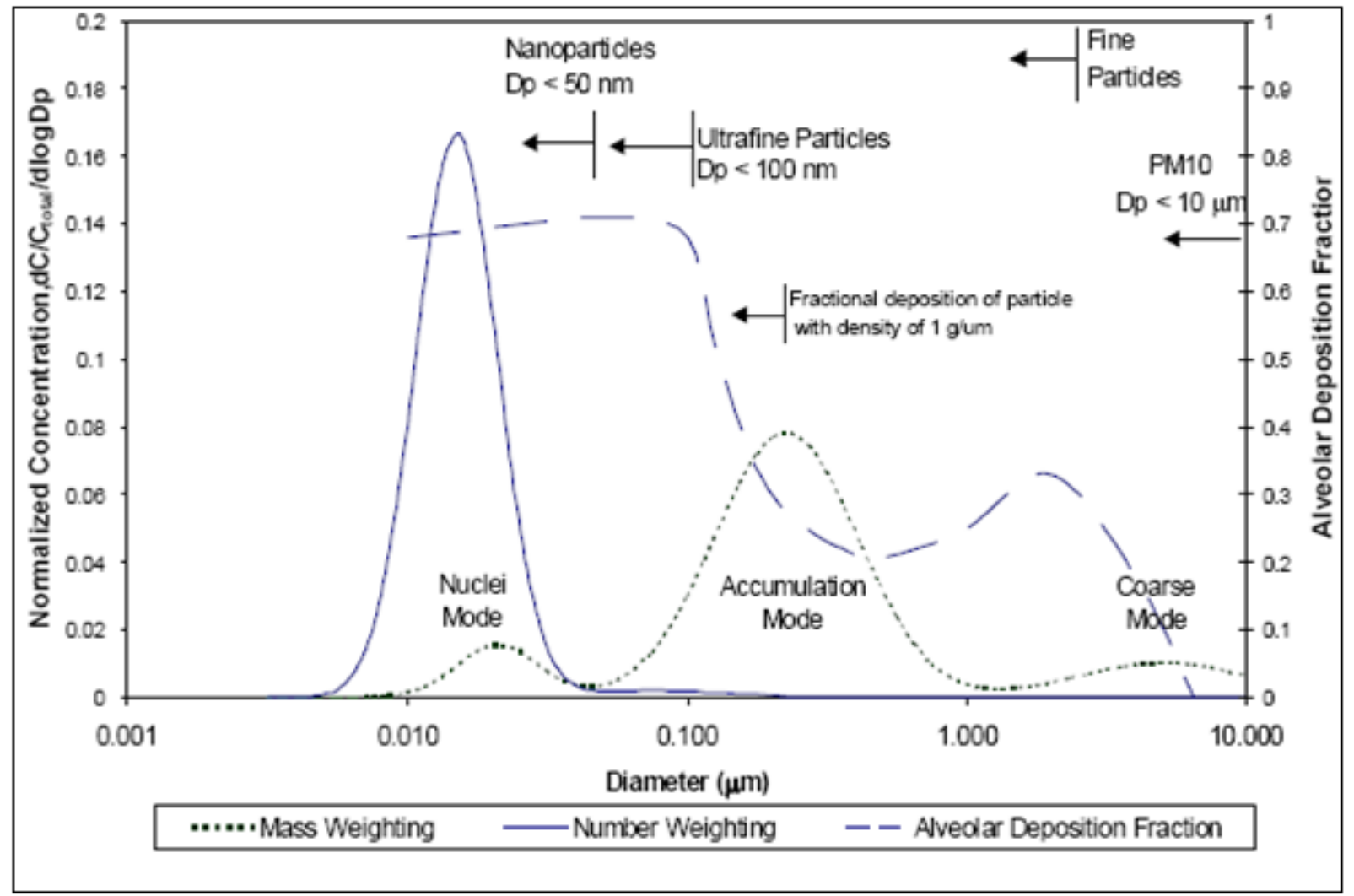

Figure 4: Diesel Particle Size and Mass Distribution, With Respiratory Deposition Curve [31]

\section{Effects of PM}

Particulate matter poses a serious threat to the human respiratory system because of its ability to penetrate the human pulmonary system. Concerns are growing over the particulate matter of smaller size which can penetrate into the lungs directly when inhaled. The particles inhaled are filtered according to their size by the branches of the human airway acting as natural impactors. Of the particles inhaled the smallest nanoparticles could directly penetrate all the way into the 
gas diffusion region of the lungs creating many lung related disorders. Volatility of PM is an issue because of the fact that the volatile PM (nano size range) could travel into the alveolar region of the lungs, and could take part in the gas exchange process in the lungs. Volatile and semi volatile particles can cause lung inflammation, cancer and gene mutations [32]. It was shown that the exhaust particle inhalation causes respiratory diseases [33].

It was shown that the diesel and gasoline engines contain metals such as lead, zinc, copper, nickel and cadmium [34]. The sources for the fine metals in exhaust can be fuel additives, lube oil additives and engine wear parts. Most of these metals have been identified as toxic to humans. These metals can be a cause for DNA damage, and influence cell permeability by creating hydroxyl compounds [32].

\subsubsection{Carbon Dioxide $\left(\mathrm{CO}_{2}\right)$}

$\mathrm{CO}_{2}$ is one of the major constituents in the exhaust of diesel combustion. Stoichiometric combustion produces more $\mathrm{CO}_{2}$. Carbon dioxide is non-toxic but is primarily associated with global warming. $\mathrm{CO}_{2}$ emissions were used for data quality assurance and to compare actual and theoretical fuel consumption values. 


\section{CHAPTER 3}

\section{FILTER SYSTEM AND EXPERIMENTAL EQUIPMENT}

\subsection{Filter System}

In this study, a silicon carbide ( $\mathrm{SiC}$ ) based wall flow diesel particulate filter was evaluated. The filter system was actively coated with Platinum Group Metals (PGM). The system was designed to meet the majority of different TRU applications operating in the North American market. The characteristics of the filter system are listed in Table 5.

Table 5: Filter System Specifications

\begin{tabular}{|c|c|}
\hline Material & SiC \\
\hline Diameter & 5.66 inches \\
\hline Length & 8 inches \\
\hline Cell density & $150 \mathrm{cpsi}$ \\
\hline Pore size & $2.36 \times 10^{-4}-7.87 \times 10^{-4}$ inches \\
\hline Porosity & $42 \%$ \\
\hline Maximum soot loading & $0.75-0.87 \mathrm{lb} / \mathrm{ft}^{3}$ \\
\hline
\end{tabular}

Wall flow filters consisting of honeycomb substrate have good filtration efficiency. The honeycomb substrate is typically made of cordierite or silicon carbide, although other materials have been used $[35,36,37]$.

The complete filter system is shown in Figure 5. The filter system includes a removable filter assembly which can be dismantled and serviced without disintegration of the whole exhaust system. The system is monitored by an electronic device measuring back pressure and exhaust temperature. This will warn the operator when filter needs to be serviced. 


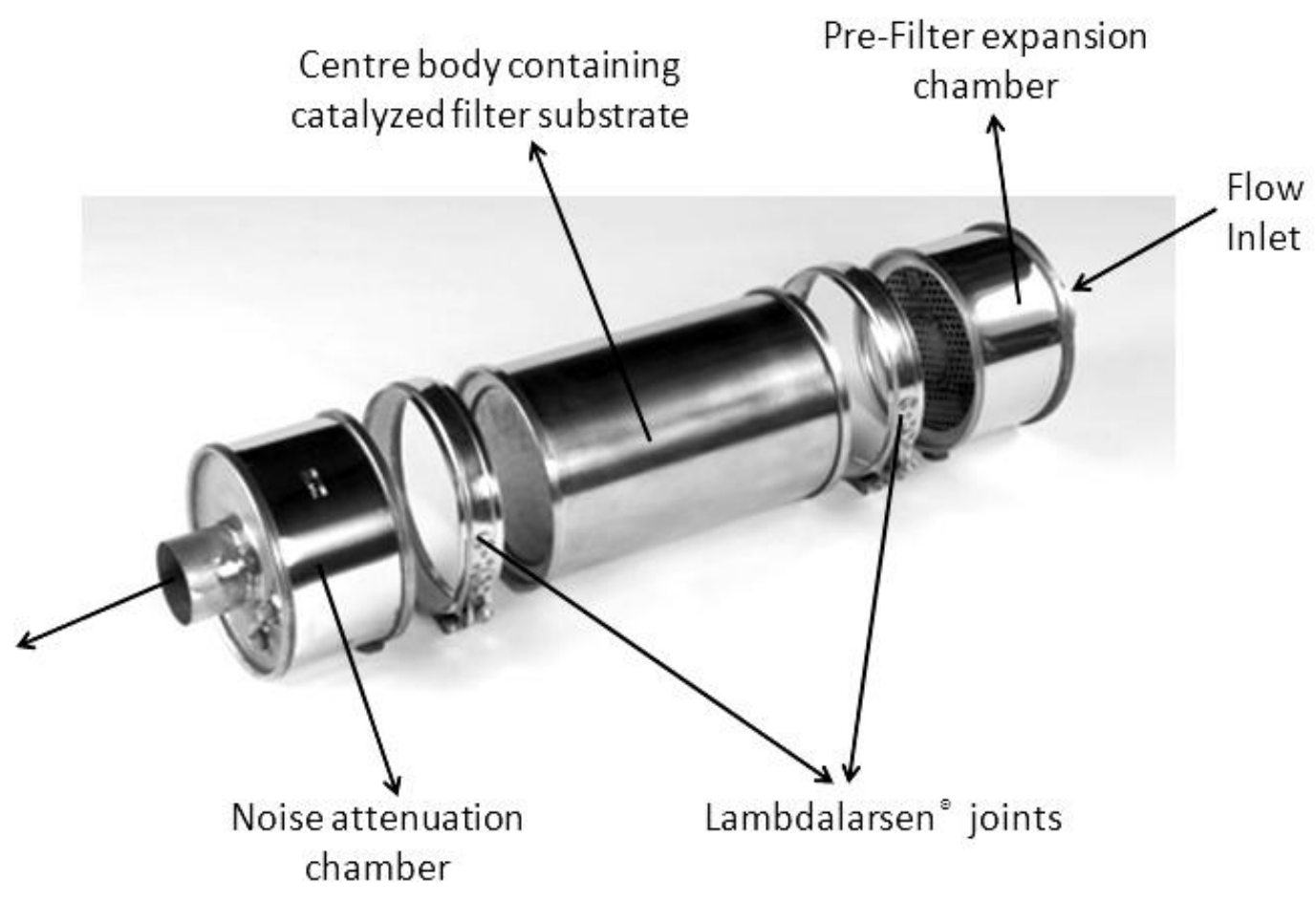

Figure 5: Filter System Used For Testing [38]

The fuel penalty can be explained by the pumping loss associated with the increase in backpressure due to the installation of filter system.

\subsubsection{Coating}

The filter was wash coated and active PGM coated to oxidize unburned hydrocarbons into $\mathrm{CO}_{2}$ and water and carbon monoxide into $\mathrm{CO}_{2}$. For $\mathrm{PM}$ regeneration, oxidation of $\mathrm{NO}$ to $\mathrm{NO}_{2}$ ensured the necessary condition for $\mathrm{NO}_{2}$ to oxidize the accumulated particulates to $\mathrm{CO}_{2}$ and water. The necessary reactions have been shown below.

$2 \mathrm{NO}+\mathrm{O}_{2} \rightarrow 2 \mathrm{NO}$

$\mathrm{C}+2 \mathrm{NO}_{2} \rightarrow \mathrm{CO}_{2}+2 \mathrm{NO}$

Equation 4 and Equation 5

The coating approach ensured adequate regeneration properties but without exceeding the legislated $20 \%$ plus baseline $\mathrm{NO}_{2}$ formation restriction. The wash coating was applied to the $\mathrm{SiC}$ substrate in a two-zone sequence to ensure a coating structure that provided adequate $\mathrm{NO}_{2}$ for regeneration purposes in combination with a coating recipe that suppressed $\mathrm{NO}_{2}$ formation at places where no PM oxidation was taking place. This implied that the filter was mono- 
directional and could not be reversed in the flow direction. The coating consisted of a wash coat of base metal oxides providing an oxygen storage capacity, combined with a low loading PGM coating.

\subsubsection{Filter System Regeneration}

The filter was designed using a substrate that was hardened in a furnace with temperatures up to $2400^{\circ} \mathrm{C}$. The filter system thereby offered higher thermal resistance and ability to withstand intensive regeneration of particles in a short period of time.

The filter system used in this study utilized passive regeneration to oxidize the soot formed on the filter. The passive regeneration was provided by chemical reactions promoted by the catalytic active wash coat containing PGM. The challenge of passive PGM promoted catalysis was the existing temperature profile in the exhaust during normal operation, raw emission levels and the legislative restriction of $\mathrm{NO}_{2}$ formation.

Figure 6 (a) shows an example of low load conditions which have low exhaust temperatures and therefore were not suitable for the passively regenerated system. This kind of duty cycle is appropriate for Level 2 VDECS or Active Regenerated Systems. Figure 6 (b) on the other hand shows a higher load duty cycle which was suitable for the passively regenerated filter system used in this study.

Selection of the appropriate after-treatment system needs to consider the wide variations of infield engine conditions, fuel and lube oil consumption, duty cycles, and temperature profiles. This results in particulate matter emissions levels that may vary almost an order of magnitude from one application to the next. Figure 6 (b) also shows high hour-to hour variations in the exhaust conditions. 


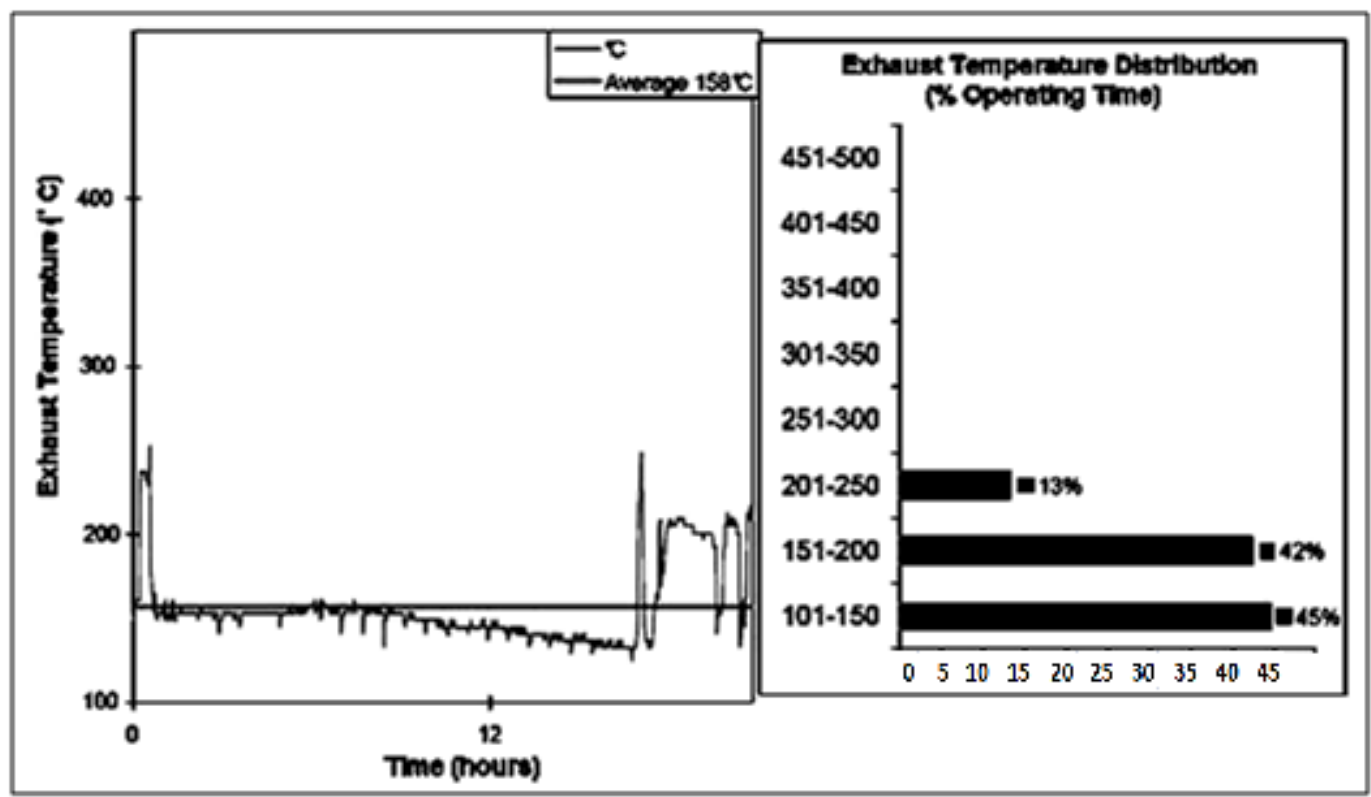

(a) Low Load Cycle Favorable for Level 2 VDECS or Active Regenerated Systems

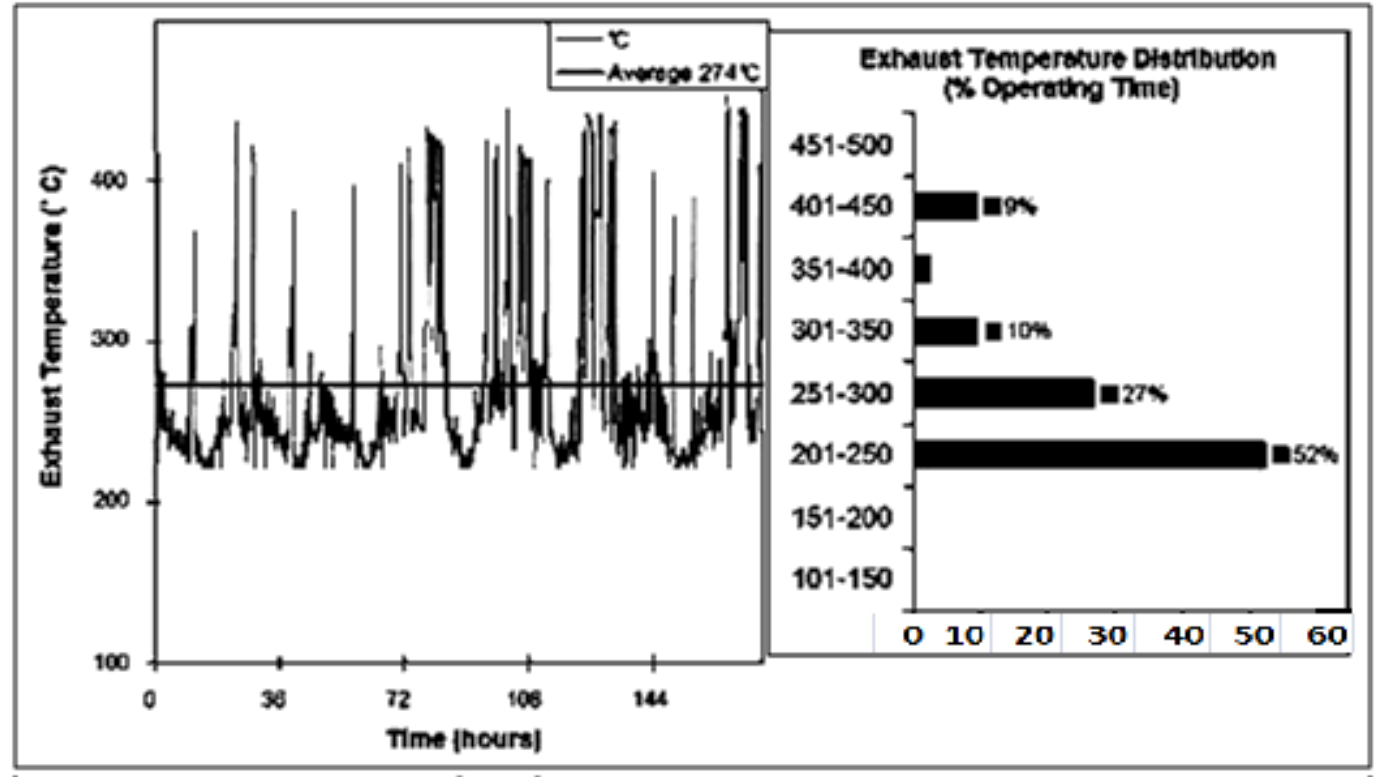

(b) High Load Cycle Suitable for Passive Regeneration Level 3 VDECS

Figure 6: Exhaust Temperature Profiles of Typical TRU Load Cycles [39] 


\subsection{Test Engine}

The test engine used in this program was a model year 1999 Kubota V2203 engine. Details of the test engine are shown in Table 6. Before starting the testing, oil filters and fuel filters were replaced with new filters; the crankcase was drained and refilled according to manufacturer's recommendations. The crankcase was filled with SAE 15W-40 heavy-duty motor oil which could be used with ULSD fuel. The engine was thoroughly inspected and the fuel injector and the fuel injection pump were rebuilt to correct leakage of fuel into the crankcase, caused by excessive fuel pump wear. The test engine was installed on a dynamometer and was run for 4 hours to stabilize the emissions following the oil change.

The useful life of the engine was defined as 10,000 hours. It should be noted that the total hours of operation for the engine was 12,214, greater than the useful life. The selection of an engine that had exceeded its useful life was intended to represent the worst case scenario that the filter system could be subjected to in use.

\subsection{Exhaust Sampling Setup}

The exhaust sampling system used in this program is shown schematically in Figure 7. The sampling system was built according to CFR 40 regulations. The total system consisted of heated probes, heated transfer lines, temperature control units and gas analyzers. The heated probes were designed such that they can provide zero and span gases to the analyzer. Heated probes were fitted inside the dilution tunnel according to the 10 diameter rule which demonstrated that the sample was collected at a distance approximately 10 diameters downstream of the mixing area [6]. The temperature of the heated lines was controlled by temperature control modules (TCM) and flow through the lines was controlled by rotameters and magnahelic pressure regulators.

The exhaust from the engine was mixed with conditioned air in the primary dilution tunnel. The sample extracted from the primary dilution tunnel was used to measure $\mathrm{HC}, \mathrm{CO}, \mathrm{NO}_{\mathrm{x}}$ and $\mathrm{CO}_{2}$ emissions from the engine. A secondary dilution tunnel was used to provide additional conditioning of the exhaust according to CFR 40, Part 89 [6] for collecting the PM emissions. 
Table 6: Test Engine Specifications

\begin{tabular}{|l|l|}
\hline Description & Specification Value \\
\hline Engine Manufacturer & Kubota \\
\hline Engine Model Name & V2203-DI-E \\
\hline Engine Serial Number & V2203-XN5092 \\
\hline Engine Model Year & 1999 \\
\hline Certification Level & Tier 1 \\
\hline Rated Power/Rated Speed & $26.8 \mathrm{~kW} / 2200 \mathrm{RPM}$ \\
\hline Maximum Torque/Max Torque Speed & $125.5 \mathrm{Nm} / 1700 \mathrm{RPM}$ \\
\hline Intermediate Speed & $1450 \mathrm{RPM}$ \\
\hline Idle Speed & $900 \mathrm{RPM}$ \\
\hline Combustion Cycle & $4-$ stroke \\
\hline Number of Cylinders/Layout & $4-\mathrm{cylinder} \mathrm{Inline}$ \\
\hline Displacement & $2,197 \mathrm{cc}$ \\
\hline Total hours of operation & 12,214 \\
\hline
\end{tabular}




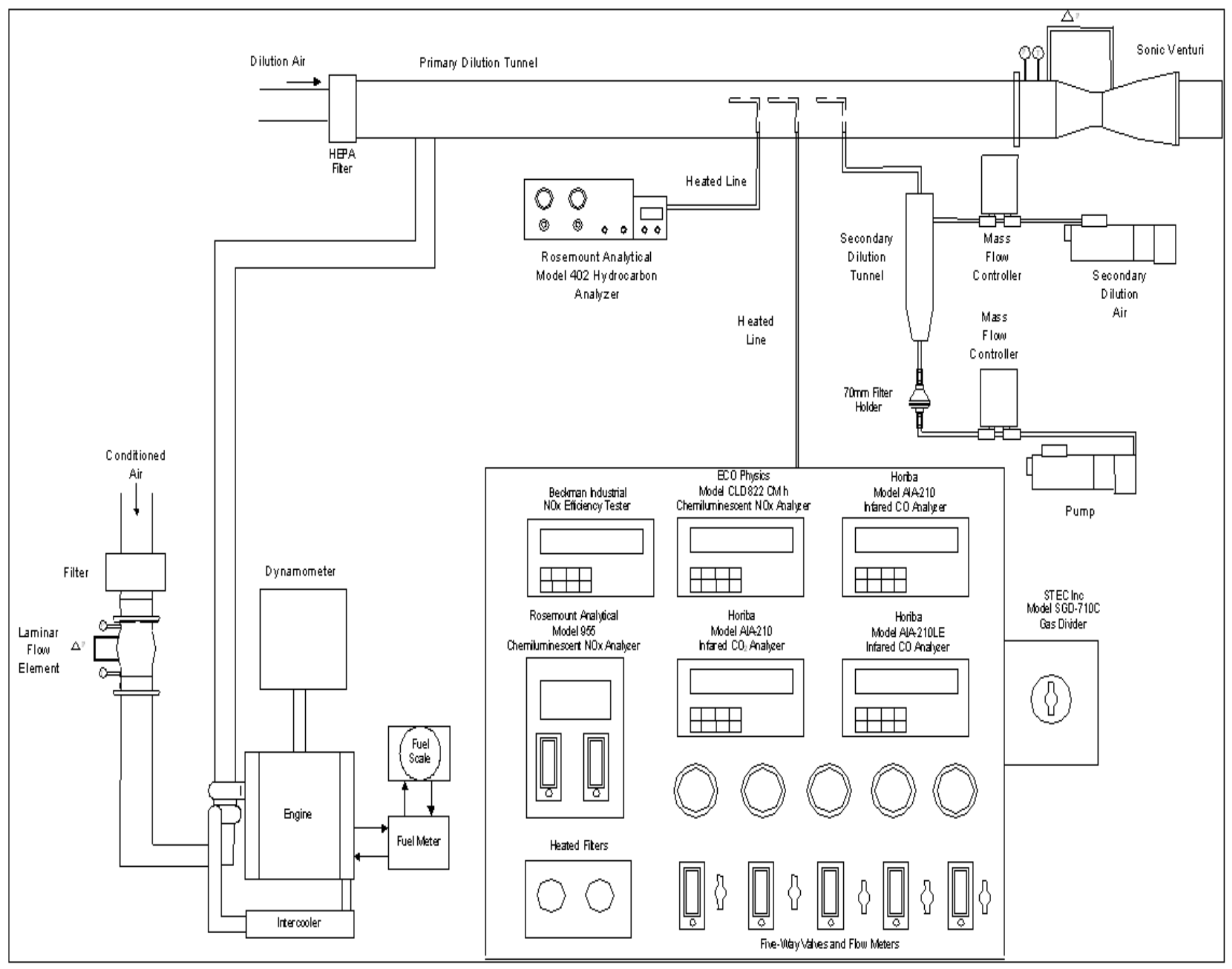

Figure 7: Schematic of Exhaust Sampling System [40] 


\subsection{Filter System De-greening}

It was important that the DPF be loaded with a representative amount of PM in order to accurately characterize the emissions of $\mathrm{NO}_{2}$. The new filter system was de-greened for two main reasons (i) to load the DPF with PM and (ii) expose the filter system to exhaust gases to stabilize the operation.

The new filter system was installed on the engine using the fixtures and fittings supplied by the manufacturer. All the valves within the exhaust system were fully opened. The filter system was de-greened by operating the test engine continuously over the modes of the EPA TRU cycle, holding each mode for 15 minutes for a period of 30 hours. The exhaust backpressure (precatalyst exhaust pressure), post catalyst exhaust pressure, differential pressure across the catalyst, and pre-and post catalyst exhaust temperatures for the last three repetitions of the EPA-TRU aging cycle were measured and recorded.

\subsubsection{Full-flow Exhaust Dilution Tunnel}

A Constant Volume Sampler (CVS) or the total exhaust double dilution tunnel was used to dilute the entire exhaust stream from the engine with temperature and humidity controlled (conditioned) air. The CVS tunnel aimed to duplicate the mixing of post-tailpipe raw exhaust with the environmental air. The temperature of the exhaust gases was reduced as they passed through the length of the CVS tunnel, hence avoiding condensation (results in loss of water soluble pollutants). Although full flow and mini dilution has been recognized as the two main dilution processes, only full flow dilution is verified for certification process by 40 CFR, Part 89 for off-road engines [6].

The dilution tunnel at EERL was designed in accordance with the CFR 40, Part 86 [41], Part 89 [6], and 30 CFR, Part 7 [43]. The full-flow system worked on the principle of Critical Flow Venturi - Constant Volume Sampler (CFV - CVS). The dilution tunnel was approximately $40 \mathrm{ft}$. in length, 18 inches in diameter and employed a $75 \mathrm{hp}$ blower to draw the diluted exhaust. Diluted exhaust was drawn by the blower through a set of four selectable venturis, three venturis having a capacity of $1000 \mathrm{scfm}$ each and one with $400 \mathrm{scfm}$ capacity. An orifice plate at the entrance to the tunnel ensured a complete mixing of raw exhaust with dilution air. 


\subsubsection{Critical Flow Venturi}

The CFV-CVS system was used to maintain the constant tunnel flow rate. When the choked condition (Mach number equal to 1) was reached, the CFV functioned under a constant mass flow rate. During this condition, the mass flow rate through the venturi was proportional to the diameter of venturi throat and upstream absolute pressure and temperature.

The mass flow rate through the venturi was given by the following equation:

$Q=K V * P / \sqrt{T}$

(Equation 6)

where,

$Q=$ flow rate in standard cubic feet per minute at standard conditions of $68^{\circ} \mathrm{F}, 29.92$ inches $\mathrm{Hg}$

$\left(20^{\circ} \mathrm{C}, 101.3 \mathrm{KPa}\right)$

$K v=$ calibration coefficient

$\mathrm{P}=$ absolute pressure at venturi inlet, inches $\mathrm{Hg}$

$\mathrm{T}=$ absolute temperature at venturi inlet, $\mathrm{K}$

\subsubsection{Regulated Emissions Sampling}

A sample was drawn from the primary dilution tunnel to measure the regulated gaseous emissions. Regulated emission components were measured by sampling diluted exhaust using stainless steel heated probes, heated sample lines, heated filters, heated pumps and gas analyzers for each emission component. The lines conducting the sample were heated to prevent the condensation of the moisture in the exhaust gas and also to prevent condensation of heavy organics in the hydrocarbon sampling system. The sampling probes connected to the temperature controlled heated lines were inserted into the tunnel facing upstream. 


\subsubsection{Particulate Sampling System and Secondary Dilution}

According to 40 CFR, Part 89 [6], a secondary dilution is required to reduce the exhaust temperature below $125^{\circ} \mathrm{F}\left(51.7^{\circ} \mathrm{C}\right)$ for complete phase transformation of semi-volatiles to particles. The diluted engine exhaust from the primary dilution tunnel was mixed with additional diluted air in the secondary dilution tunnel prior to particulate collection on to the PM filter. The PM filters used in this program were Pallfex T60A20 $70 \mathrm{~mm}$ fluorocarbon coated fiberglass filters with a filtration efficiency of $99.95 \%$. The sample was drawn from the primary dilution tunnel through a 0.5 inch diameter transfer tube located at the sampling zone. The particulate filter system used in this study complied with 40 CFR, Part 86 [41], Part 89 [6] and 30 CFR, Part 7 [43].

Background PM samples were collected from the dilution tunnel when the engine was not running in accordance with 40 CFR, Part 89 [6] and the background filter weights were used to correct the test particulate weights.

$$
P_{\text {mass }}=\left(V_{\text {mix }}+V_{s_{f}}\right) *\left(P_{f} / V_{s f}-\left(P_{b f} / V_{b f} *(1-(1 / D F))\right)\right) \quad \text { (Equation 7) }
$$

where,

$\mathrm{P}_{\text {mass }}=$ mass of particulate matter emitted during the test phase

$\mathrm{V}_{\text {mix }}=$ total volume of dilute exhaust corrected to standard conditions

$\mathrm{V}_{\mathrm{sf}}=$ volume of sample removed from the primary dilution tunnel

$\mathrm{P}_{\mathrm{f}}=$ combined weight of PM collected during a test cycle on both the primary and backup filter

$\mathrm{V}_{\mathrm{bf}}=$ volume of dilution air sampled during the background test

$\mathrm{P}_{\mathrm{bf}}=$ combined weight of PM collected on both background filters

$\mathrm{DF}=$ dilution factor given by the equation:

$D F=13.4 /(\mathrm{CO} 2 e+(\mathrm{HCe}+\mathrm{CO} e) 10-4)$

(Equation 8)

Where, subscript "e" is the gaseous emission concentration in the dilute exhaust corrected for background (ppm). 


\subsubsection{Filter Weighing Room and PM Filter Handling}

For this study, Pallfex T60A20 $70 \mathrm{~mm}$ filters were used to collect PM from the secondary dilution tunnel. The PM filters were exposed to the environment of the filter weighing room shown in Figure 8 for a minimum of 1 hour prior to weighing. The filter weighing room was maintained at the following conditions according to 40 CFR Part 89 [6]:

- Temperature: $22 \pm 3^{\circ} \mathrm{C}$

- Dew Point: $9.4 \pm 3^{\circ} \mathrm{C}$

- Relative Humidity: $45 \pm 8 \%$

Three reference filters were maintained in the weighing room at all time to serve as quality assurance in the gravimetric analysis. The reference filters were weighed before and after the emissions testing for every four hour period. In accordance with 40 CFR, Part 89 [6], if the average change in weight of the three reference filters is less than $1 \%$, the recorded sample filters weights are accepted.

The glass petri dishes that were used to store the PM filters were cleaned with an alcohol solution before being used. These dishes were kept slightly open in the weighing room to allow humidity exchange while preventing the deposition of dust (if any) onto the filters. If the sample on the filters contacted the petri dish or any other surface, the associated test was declared void and was re-run. Tweezers were used to handle the PM filters while installing and removing the filters from the filter holder and also while weighing. 


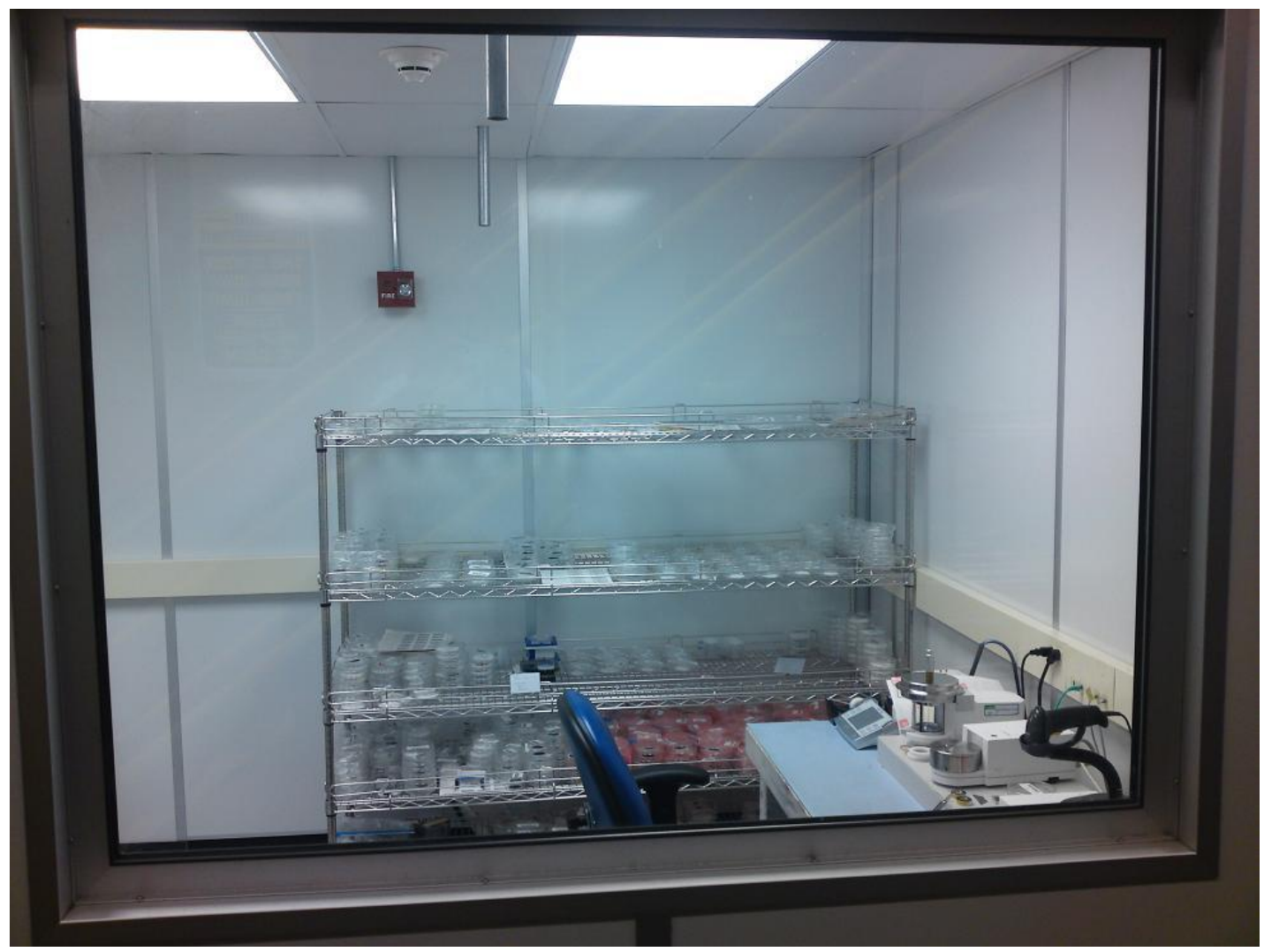

Figure 8: Filter Weighing Room

\subsubsection{Microbalance}

The Sartorius SE2-F microbalance shown in Figure 9 was used to measure the weights of PM filters. The instrument was stored on a vibration isolation table in the filter weighing room. Nucleospot $^{\mathrm{TM}}$ Polonium-210 charge neutralizer was used to remove the static charge from the filters prior to weighing. The balance was calibrated with National Institute of Standards and Technology (NIST) traceable weights. 


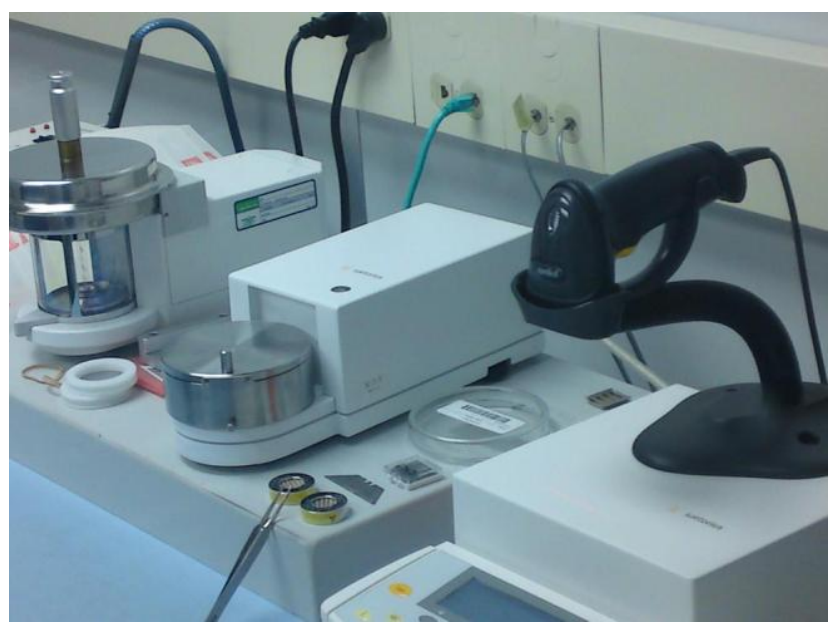

Figure 9: Microbalance

\subsubsection{Gas Divider}

A gas divider shown in Figure 10 was used to calibrate the gas analyzers. Calibration gases with $1 \%$ accuracy traceable to NIST standards were used and a ten point calibration curve was generated. Stepped input to the analyzers was provided by a STEC Inc. SGD-710C gas divider. The gas divider was installed with two inlet ports, one port served for the balance air or zero gases, a second/ output port supplied the blended gas to an analyzer for the span gas. The mass flow rate of the gas through the capillaries was proportional to the pressure drop across the capillaries. The gas was supplied to the gas divider in increments of $10 \%$ of span concentration.

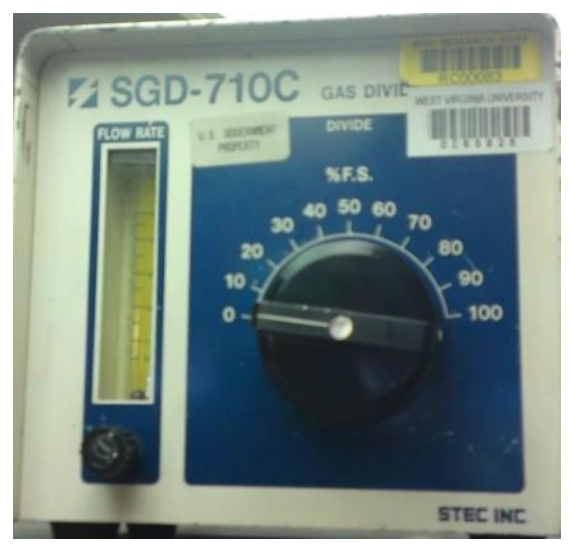

Figure 10: Gas Divider 


\subsubsection{Exhaust Sample Gas Analyzers}

The concentrations of the different emission components from the primary dilution tunnel were analyzed by the gas analyzers. The gas analyzer bench shown in Figure 11 was used in this study. The gas analyzers are discussed in the subsequent paragraphs.

All the analyzers were calibrated using the standard calibration gas and were set to a range which can measure the emissions from the test engine. Calibrations were performed in accordance with the CFR 40 Part 89 [6].

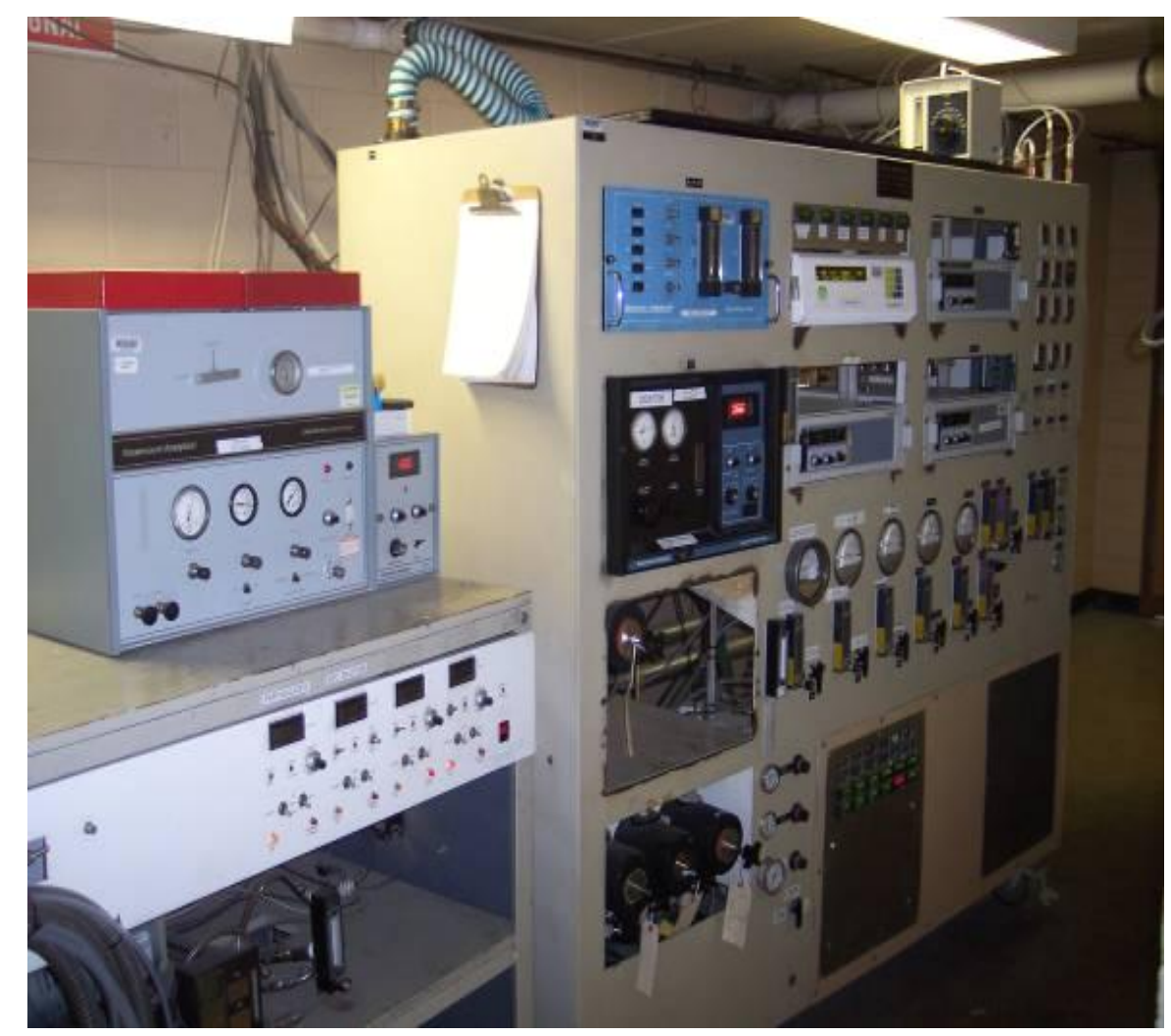

Figure 11: Analyzer Bench 


\subsubsection{NO $\mathrm{O}_{x}$ Analyzer}

Chemiluminescence means a chemical reaction that produces light. $\mathrm{A} \mathrm{NO}_{\mathrm{x}}$ analyzer works on the principle of chemiluminescence to measure $\mathrm{NO}$ or $\mathrm{NO}_{x}$. Chemiluminescence is recognized as a sensitive, selective, and linear measurement of $\mathrm{NO}_{\mathrm{x}}$ in wide variety of applications.

Two wet chemiluminescent analyzers were used to determine the concentration of $\mathrm{NO}_{\mathrm{x}}$ and $\mathrm{NO}_{2}$ in this study. This instrument can be operated in two modes, $\mathrm{NO}$ and $\mathrm{NO}_{\mathrm{x}}$ modes. In $\mathrm{NO}$ mode, the principle is based on the reaction between ozone and $\mathrm{NO}$ as shown below:

$\mathrm{NO}+\mathrm{O}_{3} \rightarrow \mathrm{NO}_{2}^{\mathrm{b}}+\mathrm{O}_{2}$

$\mathrm{NO}_{2}^{\mathrm{b}} \rightarrow \mathrm{NO}_{2}+\mathrm{hv}$

The mass flow rate of NO was proportional to the release of photon molecules in the sample. This photon molecule was detected by the photon detector or the multiplier tube which produced a low level DC current. The reading was recorded on the front panel of the instrument which produced a response of 0 to 5 volts. In the $\mathrm{NO}_{\mathrm{x}}$ mode, $\mathrm{NO}_{2}$ was catalytically converted to $\mathrm{NO}$ in a $\mathrm{NO}_{\mathrm{x}}$ converter. The working principle was similar to that of the NO mode.

In order to prevent condensation on the line walls, the sample line was heated and maintained at $250{ }^{\circ} \mathrm{F}\left(121^{\circ} \mathrm{C}\right)$ and the detector operating pressure was atmospheric. For maximum $\mathrm{NO}_{2}$ conversion efficiency, the $\mathrm{NO}_{\mathrm{x}}$ converter was maintained between $660^{\circ} \mathrm{F}\left(350^{\circ} \mathrm{C}\right)$ and $750{ }^{\circ} \mathrm{F}$ $\left(399^{\circ} \mathrm{C}\right) . \mathrm{A} \mathrm{NO}_{\mathrm{x}}$ efficiency test was performed to check that the converter efficiency was always $>90 \%$. The $\mathrm{NO}_{\mathrm{x}}$ analyzer required a balance gas and a span gas. Nitrogen was used as a balance gas and air to supply oxygen for ozone generation.

Effective January 1, 2009 diesel emissions control systems were restricted from increasing $\mathrm{NO}_{2}$ emissions by more than an increment equivalent to $20 \%$ of the baseline $\mathrm{NO}_{\mathrm{x}}$ emission level. The average $\mathrm{NO}_{2}$ emissions from the engine-out testing and DPF-out TRU cycle emissions testing were used to determine the incremental $\mathrm{NO}_{2}$ increase attributed to the diesel emissions control system. 


\subsubsection{HC Analyzer}

A Heated Flame Ionization Detector (HFID) is commonly used for total hydrocarbon measurement. In this study, A Horiba FIA-236 HFID was used to measure the concentration of THC in the dilution tunnel.

The number of carbon atoms present in the sample is used to determine the HC concentration. A controlled mixture of air, hydrogen and helium is used to produce a premixed flame which ionizes the sample gas. These ions are attracted by the polarized electrodes producing a current in the medium. The current produced is proportional to the number of carbon atoms in the sample, which is related to the HC concentration of the sample [44].

\subsubsection{3 $\mathrm{CO} / \mathrm{CO}_{2}$ Analyzer}

Non-dispersive infrared analyzers (NDIRs) were used as a gas detector to measure $\mathrm{CO}$ and $\mathrm{CO}_{2}$. NDIRs are based on the principle that each type of gas component shows a unique absorption line spectrum in the infrared region. The popularity of NDIRs is due to a number of design features, such as their construction, durability, high selectivity, and a capacity for continuous analysis [45].

The NDIR consists of an infrared light source, a chopper, a measuring cell, and a detector filled with a gas mixture containing the gas component to be measured. The components of a typical NDIR are shown in Figure 12. The infrared light source emits infrared light in all directions which is transmitted and reflected into the detectors [45].

A chopper blade is arranged between the infrared light source and the measuring cell to modulate the infrared light beam at a regular frequency. Both the front and rear chambers of the detector are filled with the gas component to be measured. The infrared light energy is partially absorbed in the front chamber and residual light is absorbed in the rear chamber, thereby increasing the pressure in both the chambers. Since the detector is designed to produce a pressure difference between the front and rear chambers, a slight gas flow is produced through a path connecting these chambers with each other. This slight gas flow is converted into an AC electrical signal by a microflow sensor arranged in the path connecting the chambers with each other. The AC signal is amplified and rectified to a DC voltage supplied to the output terminals and indicator [45]. 


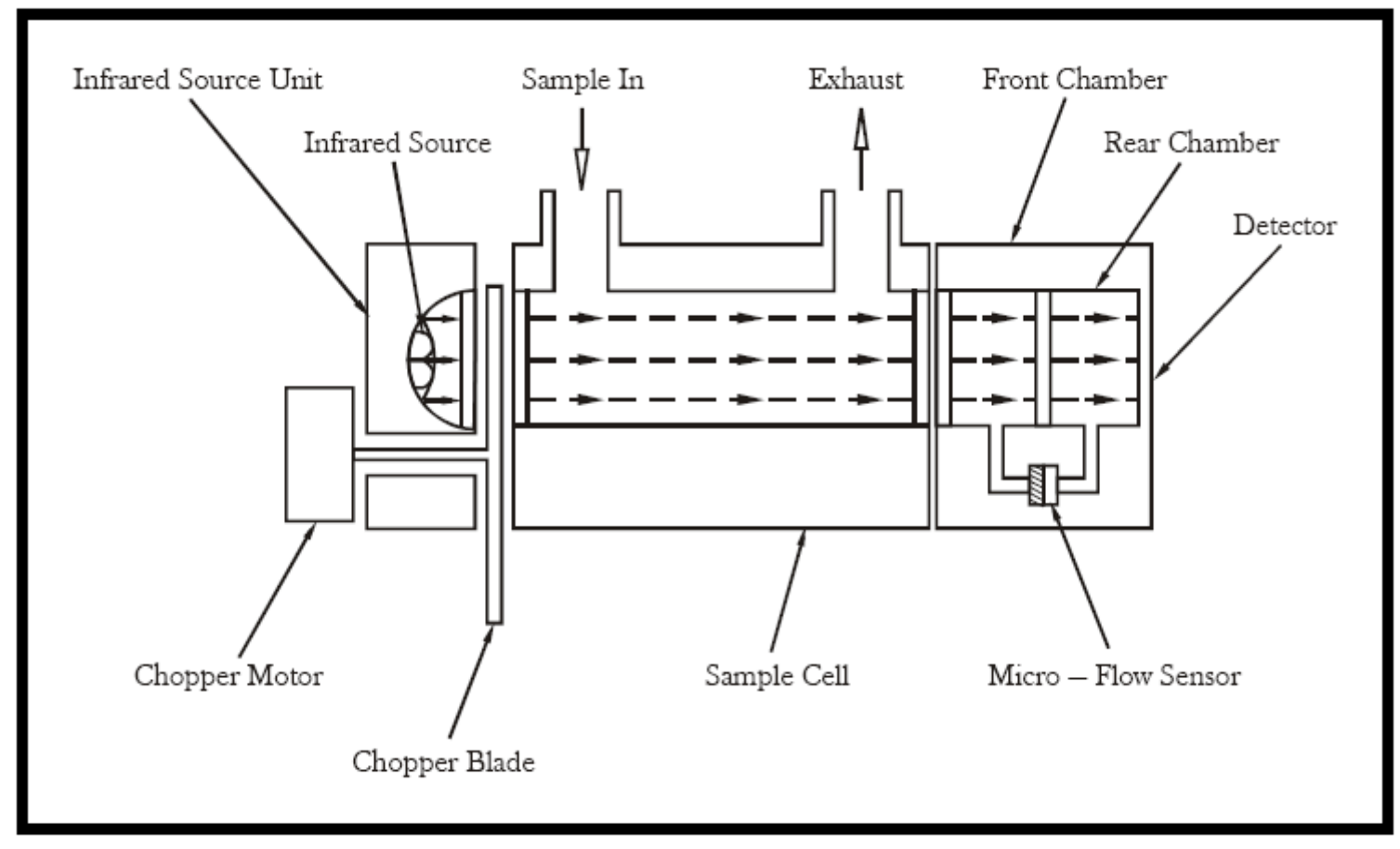

Figure 12: Single NDIR Analyzer [45]

\subsubsection{Bag Sampling}

Eighty (80) liter Tedlar ${ }^{\mathrm{R}}$ bags shown in Figure 13 were used to collect the samples from the diluted exhaust and the background air in the dilution tunnel. These samples were analyzed after completion of each test by the analyzers. 


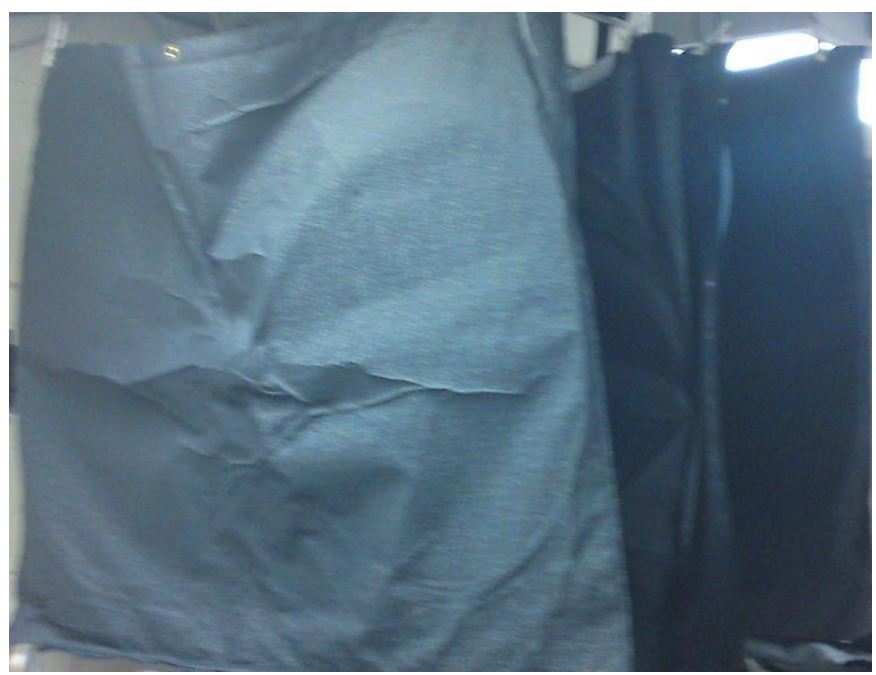

Figure 13: Tedlar Bags

The concentrations from the samples were measured and the $\operatorname{Tedlar}^{\mathrm{R}}$ bags were evacuated before starting the next test. The dilute samples and continuous readings were corrected by measuring the background concentrations. Correction was made by the following equation:

$\left[X_{\text {mass }}\right]=\sum\left[\frac{\left[X_{e}\right]_{i}}{10^{6}} \times\left(V_{\text {mix }}\right)_{i} \times\right.$ density $\left._{x} \times \Delta T\right]-\frac{[X]_{d}}{10^{6}} \times\left(1-\frac{1}{D F}\right) \times V_{\text {mix }} \times$ desnsity $_{x}[41] \quad$ (Equation 11)

Where,

$\mathrm{X}=$ the emission component being evaluated

e, $\mathrm{i}$ and $\mathrm{d}=$ Instantaneous emission component concentration of the dilute exhaust obtained from the analyzer readings (ppm), instantaneous dilute exhaust flow through CFV (scfm), and concentration of emission component in dilution air corrected for water vapor (ppm), respectively.

$\mathrm{V}_{\text {mix }}=$ total dilute exhaust volume in cubic feet per test phase corrected to standard conditions

Desnsity $_{\mathrm{x}}=$ density of emissions species being evaluated

DF = dilution factor (40 CFR, Part 86 [41] and 40 CFR, Part 89 [6]) 


\subsubsection{Dynamometer}

In the laboratory, a dynamometer was used to apply the required load on the engine. Based on the load required and the size of the engine, an air-cooled eddy current dynamometer was used. The dynamometer used was capable of absorbing $100 \mathrm{hp}$ continuously with a peak of $280 \mathrm{hp}$ and could be operated up to $6000 \mathrm{rpm}$. A Dynloc-IV digital controller was used to record the speed and torque values. The fuel rack was controlled by Dyne Systems Co. DTC-1 digital throttle controller, while a computer was used to vary the load applied by the dynamometer. The throttle controller was connected with the torque controller and a throttle actuator and was installed on to the engine fueling linkage. The dynamometer and throttle controller used in this study are shown in Figure 14 and Figure 15, respectively.

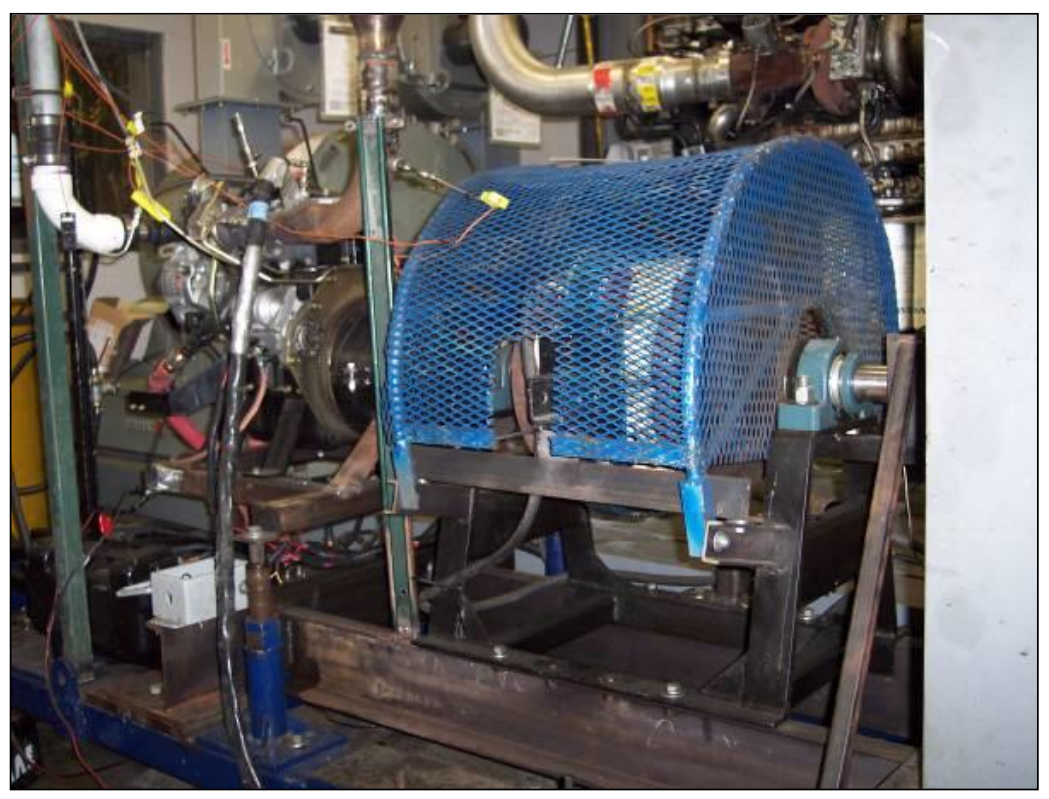

Figure 14: Air-cooled Eddy Current Dynamometer 


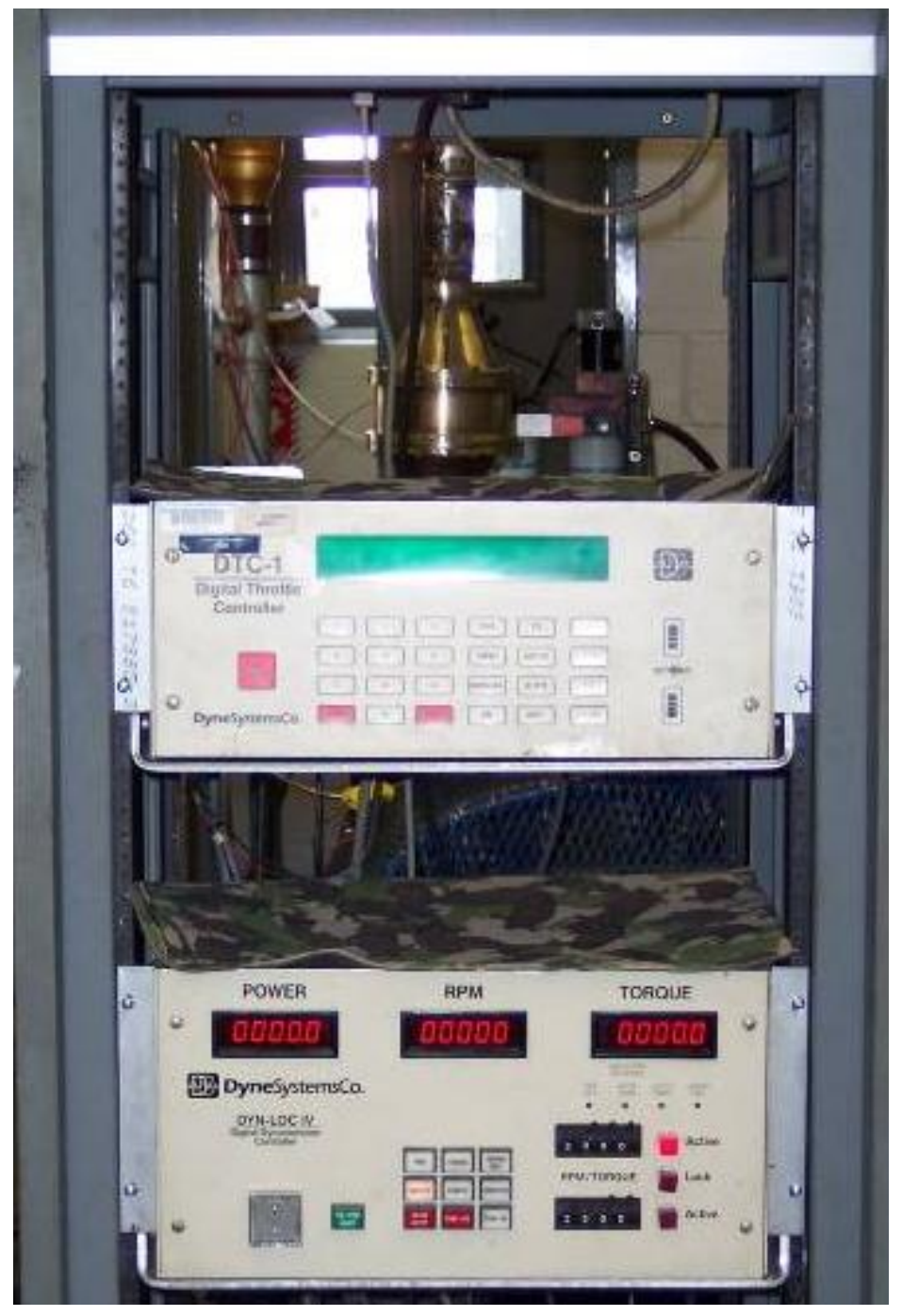

Figure 15: Dyne Systems Co. DTC-1 Digital Throttle Controller 


\section{CHAPTER 4 \\ TESTING RESULTS}

\subsection{Introduction}

The objective of the current study was to evaluate a diesel emissions control strategy as a Level 3 VDECS under CARB regulation 2702 [1]. The leaking fuel injector was repaired and the fuel injection pump was rebuilt. No other modifications were made to the performance characteristics of the engine and the particulate filter system tested. The backpressure on the filter system equipped tests was maintained such that the values did not exceed $30 \%$ of the backpressure values from the baseline testing for the same test cycle. The results generated from this study were used to evaluate this particular system as a Level 3 VDECS according to CARB regulations.

Prior to conducting the emissions testing, the filter system was de-greened for 30 hours continuously over the modes of EPA TRU cycle. The exhaust temperatures and backpressure were measured continuously such that they did not exceed the manufacturer specifications.

In this study, the TRU engine and the filter system were sequentially subjected to pre-durability and post-durability testing. Engine mapping was conducted to determine the engine speed and torque set points on the test fuel. Table 3 and Table 4 show the torque and speed set points of the ISO-8178 C1 [2] cycle and the EPA TRU [3] cycle, respectively. The engine-out and DPF-out emissions were measured under steady-state cycle ISO-8178 C1 [2] cycle only. The data from the ISO 8178-C1 [2] cycle was used to compute results for the 4-mode EPA TRU [3] cycle based on the example calculations provided by CARB. This translation eliminated the necessity to run the 4-mode EPA TRU [3] test cycle in the laboratory.

\subsubsection{Pre and Post Filter Exhaust Temperatures}

Exhaust temperatures were measured before and after retrofitting the filter (trap) system to the engine. The pre and post-filter exhaust gas temperatures were recorded at a frequency of $1 \mathrm{~Hz}$ for the last three hours of the de-greening process over the 4-mode EPA TRU [3] cycle as shown in Figure 16. 


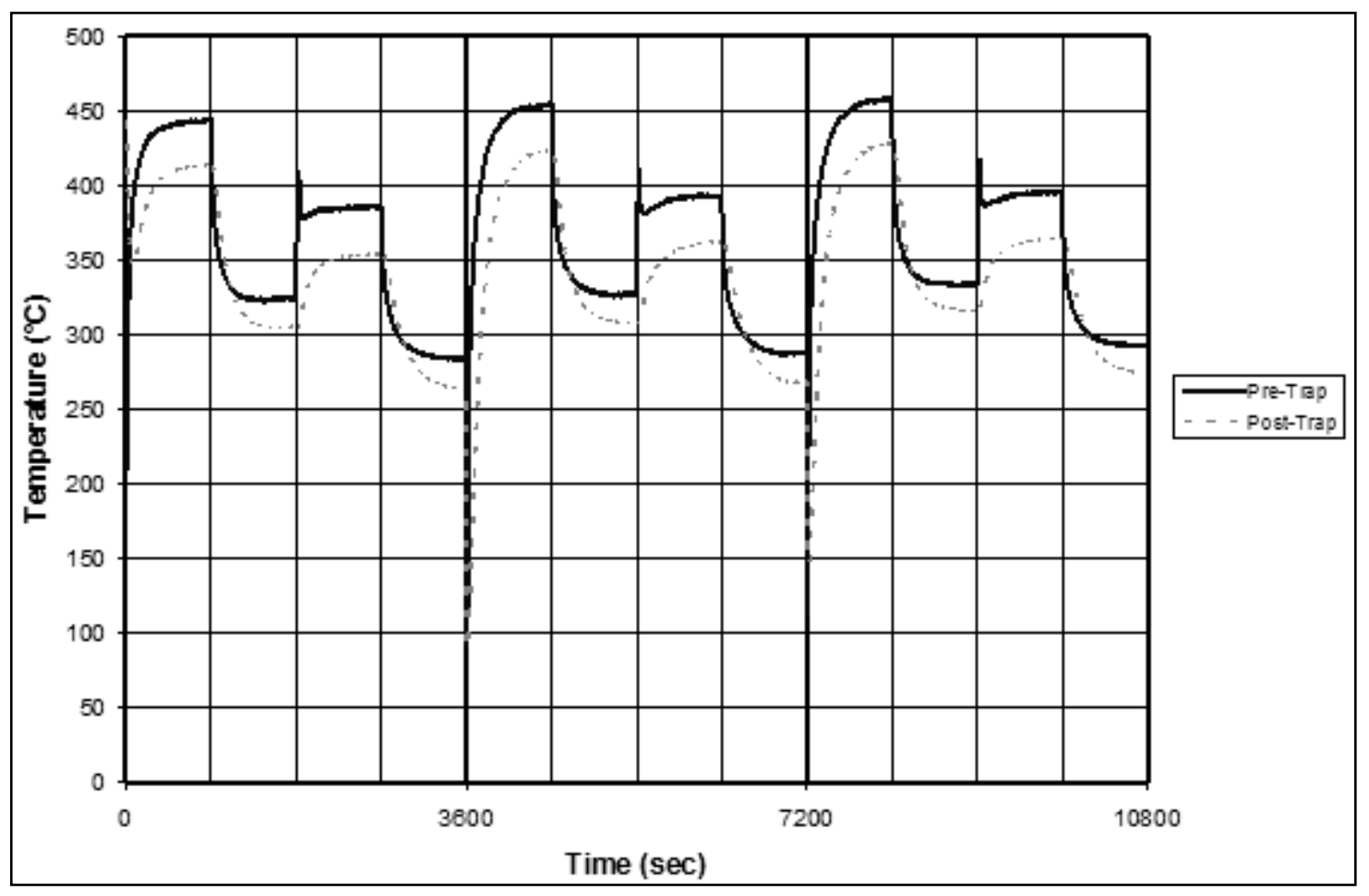

Figure 16: Pre and Post-filter Exhaust Gas Temperature

\subsubsection{Exhaust Backpressure}

The filter system was installed in the exhaust system of the engine and was preconditioned over the modes of the EPA TRU cycle for 30 hours. The exhaust backpressure was recorded at a frequency of $1 \mathrm{~Hz}$ for the last three hours of operations as shown in Figure 17. The average backpressure recorded during the last three hours of operation, which consisted of three repeats of each mode of the EPA TRU cycle was used as the initial backpressure. The average backpressure values are given in Table 7. This initial backpressure was used to determine whether the backpressure of the "aged" filter (following accumulation of 1000 hours of inservice operation) was within $30 \%$ of the pre-durability value prior to proceeding with the postdurability emissions testing. 
Table 7: Exhaust Backpressure (in $\mathrm{H}_{2} \mathrm{O}$ )

\begin{tabular}{|c|c|c|c|c|}
\hline Mode & Run 1 & Run 2 & Run 3 & Average \\
\hline 1 & 32.5 & 42.8 & 46.6 & 40.6 \\
\hline 2 & 31.8 & 41.2 & 44.7 & 39.2 \\
\hline 3 & 24.3 & 30.4 & 32.7 & 29.1 \\
\hline 4 & 22.9 & 28.2 & 30.2 & 27.1 \\
\hline
\end{tabular}

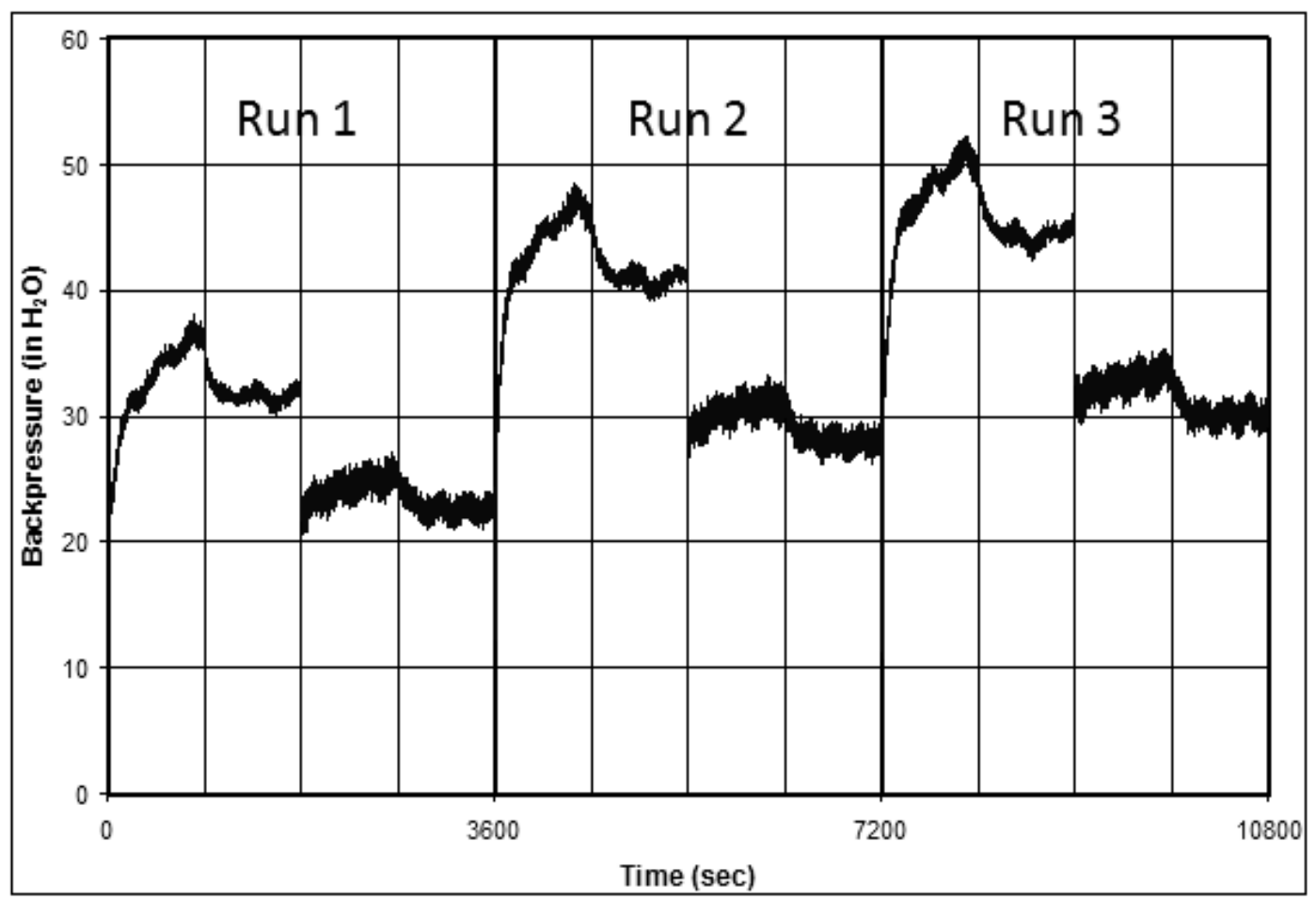

Figure 17: Exhaust Backpressure (in $\mathrm{H}_{2} \mathrm{O}$ ) Recorded During the Last Three Repeat Runs of EPA TRU 4 Mode Cycles for Preconditioning the Filter System 


\subsubsection{Procedure for Calculations}

The brake specific emissions (g/bhp-hr) for each component and for all the emission tests were calculated and expressed [46] as:

BrakeSpecific Emissions $(g / b h p-h r)=\left(\sum(\text { Emissions rate })_{i} *(W F)_{i}\right) /\left(\sum(\text { Power })_{i} *(W F)_{i}\right)$

(Equation 12)

Where

WF - weighting factor

$\mathrm{i}$ - the mode number

$(\text { Emissions rate })_{\mathrm{i}}$ - the average mass flow rate in $\mathrm{g} / \mathrm{hr}$ for mode $\mathrm{i}$ given by

$(\text { Emissions rate })_{i}=$ Emissions mass $($ grams $/$ mode $) /$ Mode length in hours

(Equation

$(\text { Power })_{i}$ - the average power for mode i given by

$(\text { Power })_{i}=$ Integrated work $($ bhp $-h r) /$ Mode length in hours

(Equation 14)

The percentage reduction for all the regulated emissions of engine-out and DPF-out testing pair was calculated as per CCR $13 \S 2708$ [47], defined as the difference between average engine-out and average DPF-out emissions divided by the average baseline.

$\%$ Reduction $=100 \times \sum\left((\text { engine }- \text { out })_{\text {avg }}-(D P F-\text { out })_{\text {avg }}\right) /(\text { engine }- \text { out })_{\text {avg }} /$ Number of Tests

(Equation 15) 


\subsubsection{Procedure for 95\% Confidence Interval Calculation}

A statistical approach was implemented for an estimation of error analysis. A 95\% confidence was calculated for three repeat tests, the margins of error could have been reduced by increasing the number of tests [48].

(i)A $95 \%$ confidence interval for mean $\mu$ is given by

$$
x \pm z * \times \sigma / \sqrt{n}
$$

Where, $\mathrm{x}$ - sample mean

$(z * \times \sigma / \sqrt{n})-$ margin of error for $95 \%$ confidence

$\mathrm{z}^{*}-4.303$ from $\mathrm{t}$-distribution table for $95 \%$ confidence and $\mathrm{df}=2$

$\sigma$ - Standard deviation

$\mathrm{n}$ - number of samples

(ii) error $(\%)=($ margin of error for $95 \%$ confidence $/$ mean $) * 100$

95\% confidence interval sample calculation for pre-durability PM emission:

margin of error for $95 \%$ confidence $=z * \times \sigma / \sqrt{n}$

$\mathrm{z}^{*}-4.303$ from $\mathrm{t}$-distribution table for $95 \%$ confidence and $\mathrm{df}=2$

$\sigma=0.024$

$\mathrm{n}=3$

mean $=0.775$

Therefore, margin of error for $95 \%$ confidence $= \pm 0.059$ and error $\%=7.7 \%$ 


\subsection{Pre-Durability Emission Testing}

Pre-durability emissions testing consisted of all the emissions tests prior to 1000 hours aging of the filter system. The testing included baseline engine-out and DPF-out emissions with the particulate filter system installed in the exhaust system. Emissions from three repeat runs of each configuration were measured.

\subsubsection{Engine Lug Curve}

The engine was thoroughly warmed-up in accordance to 40 CFR $\S 89.407$ [6] in order to stabilize the oil and coolant temperatures. Engine warming was followed by full power lug curves to determine the ISO 8178-C1 speed/torque set points. Engine mapping was performed by sweeping the engine through its operating speed range from curb idle to a maximum speed determined by:

m axi m urspeed $=\mathrm{i}$ dl $\propto \mathrm{pm}+\frac{105(\mathrm{~m} \text { easur edat ed } \mathrm{pm}-\mathrm{i} \mathrm{dl} \propto \mathrm{pm})}{100}$

(Equation 17)

During the sweeping process, the engine speed was allowed to increase at an average rate of 8 $\mathrm{rpm} / \mathrm{sec}$ by the dynamometer, while the engine throttle was set to full load. Multiple lug-curves were recorded to demonstrate consistency. The average of the multiple lug-curves was used as the final lug-curve to compute the ISO 8178-C1 [2] cycle speed/torque set points. The final lugcurve is shown in Figure 18. These performance measures were in agreement with the manufacturer's performance specifications shown in Table 6. 


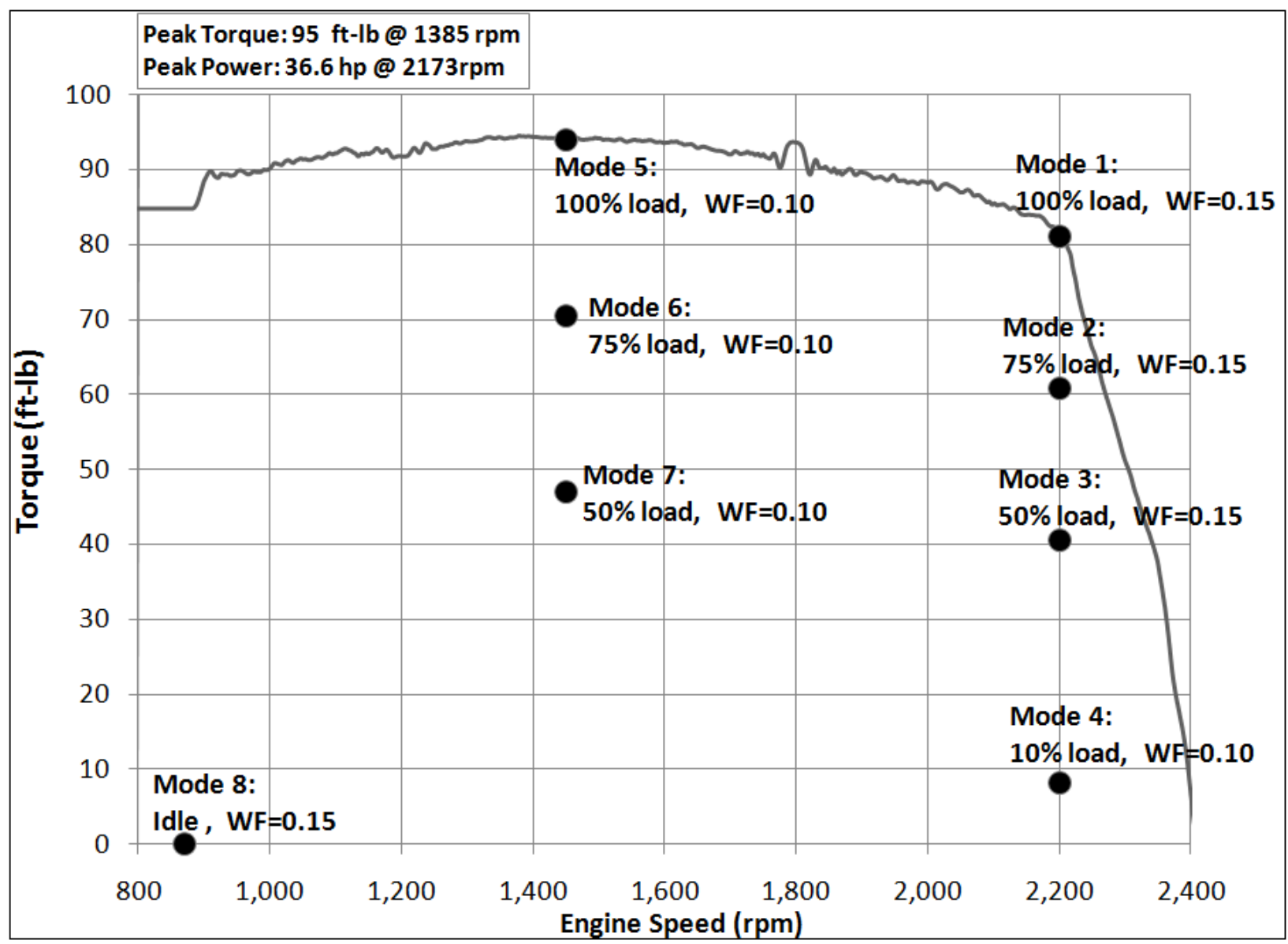

Figure 18: Pre-durability Lug-curve

\subsubsection{Test Cycle}

For both Pre-durability and Post-durability testing, emissions of the TRU engine were measured over the 8-mode ISO 8178-C1 [2] cycle, shown in Table 8. Mode lengths were designed to allow proper stabilization of emissions prior to data collection. Sample times were designed to allow adequate deposition of particulate matter on the sample media for assuring accurate weighing of the filters. Data collection occurred at the end of each mode. Mode length and sample time for the ISO 8178-C1 cycle for engine-out and DPF-out conditions have been given in Table 8.

The data from the ISO 8178-C1 [2] cycle was used to compute results for the 4-mode EPA TRU [3] cycle, shown in Table 9. 
Table 8: ISO 8178-C1 Test Cycle with Performance Specifications

\begin{tabular}{|c|c|c|c|c|c|c|c|c|}
\hline Mode & 1 & 2 & 3 & 4 & 5 & 6 & 7 & 8 \\
\hline Weighting Factor & 0.15 & 0.15 & 0.15 & 0.10 & 0.10 & 0.10 & 0.10 & 0.15 \\
\hline Speed & \multicolumn{4}{|c|}{ Rated Speed } & \multicolumn{3}{|c|}{ Intermediate Speed } & Idle \\
\hline$(\mathrm{rpm})$ & \multicolumn{4}{|c|}{ (2200) } & \multicolumn{3}{|c|}{$(1450)$} & $(870)$ \\
\hline Torque, $\%$ & 100 & 75 & 50 & 10 & 100 & 75 & 50 & - \\
\hline (ft-lb) & (84) & $(65)$ & (43) & $(8.7)$ & $(97)$ & $(74)$ & (49) & - \\
\hline & \multicolumn{8}{|c|}{ Engine-Out Tests } \\
\hline Mode Length, sec & 600 & 600 & 600 & 600 & 600 & 600 & 600 & 600 \\
\hline \multirow[t]{2}{*}{ Sample Time, sec } & 120 & 240 & 240 & 240 & 240 & 240 & 240 & 360 \\
\hline & \multicolumn{8}{|c|}{ DPF-out Tests } \\
\hline Mode Length, sec & 900 & 900 & 1200 & 1500 & 900 & 1200 & 1200 & 1200 \\
\hline Sample Time, sec & 600 & 600 & 900 & 900 & 600 & 900 & 900 & 900 \\
\hline
\end{tabular}

Table 9: EPA TRU Test Cycle with Performance Specifications

\begin{tabular}{|c|c|c|c|c|c|c|c|c|}
\hline Mode & 1 & 2 & 3 & 4 & 5 & 6 & 7 & 8 \\
\hline Weighting Factor & & 0.25 & 0.25 & & & 0.25 & 0.25 & \\
\hline Speed & \multicolumn{4}{|c|}{ Rated Speed } & \multicolumn{3}{|c|}{ Intermediate Speed } & Idle \\
\hline (rpm) & \multicolumn{4}{|c|}{ (2200) } & \multicolumn{3}{|c|}{ (1450) } & $(870)$ \\
\hline Torque, $\%$ & - & 75 & 50 & - & - & 75 & 50 & - \\
\hline (ft-lb) & - & $(65)$ & (43) & - & - & (74) & (49) & - \\
\hline
\end{tabular}




\subsubsection{Test Fuel Analysis}

The test fuel used in this study was an alternative diesel fuel formulation from BP that was verified by CARB. Preconditioning of the engine and filter system and all the emissions tests were conducted using ultra-low sulfur $(<15$ ppm S) diesel fuel meeting the requirements of 13 CCR § 2280-2283 [49]. Prior to procuring the test fuel a pre-test fuel analysis was performed by Analysts Incorporated. Triplicate analysis was performed on the test fuel by Intertek Caleb Brett. The fuel analysis results are given in Table 10.

Table 10: Fuel Analysis Results

\begin{tabular}{|c|c|c|c|c|}
\hline Property, Units - ASTM Method & $\begin{array}{c}\text { Pre-Test } \\
\text { Analysis }\end{array}$ & $\begin{array}{c}\text { Replicate } \\
\text { No. 1 }\end{array}$ & $\begin{array}{c}\text { Replicate } \\
\text { No. 2 }\end{array}$ & $\begin{array}{c}\text { Replicate } \\
\text { No. 3 }\end{array}$ \\
\hline Distillation, F - D86 & & & & \\
\hline Initial Boiling Point & 337 & 331 & 340 & 341 \\
\hline Recovered - 5\% & 372 & 371 & 371 & 371 \\
\hline Recovered -95\% & 632 & 638 & 638 & 639 \\
\hline Final Boiling Point & 655 & 655 & 659 & 661 \\
\hline Recovery - \% vol & 99 & 98.2 & 98.3 & 98.2 \\
\hline Residue - \% vol & 0.5 & 1.2 & 1.2 & 1.4 \\
\hline Loss - \% vol & 0.5 & 0.6 & 0.5 & 0.4 \\
\hline Viscosity @ 40 C, cSt - D445 & 2.1 & 2.13 & 2.13 & 2.13 \\
\hline Sulfur Content, ppm - D5453 & 4.8 & 5 & 4 & 5 \\
\hline Aromatics, wt \% - D5186 & & & & \\
\hline Mono-aromatics & 18.7 & 19.1 & 19.1 & 19.1 \\
\hline Poly-nuclear aromatics & 3.6 & 4.1 & 3.8 & 3.9 \\
\hline Total aromatics & 22.3 & 23.2 & 22.9 & 23.0 \\
\hline API Gravity, deg API - D287/D1298 & 39.7 & 39.9 & 39.9 & 39.9 \\
\hline Cetane Number - D613 & 52.5 & 51.8 & 51.7 & 51.7 \\
\hline Flashpoint PMCC, F - D93 & 150 & 138 & 138 & 137 \\
\hline Nitrogen, mg/kg - D4629 & 19.3 & 22 & 22 & 22 \\
\hline
\end{tabular}




\subsection{4 $\mathrm{NO}_{\mathrm{x}}$ Analyzer Correlation Test}

Prior to starting the emissions test, a trail run of ISO 8178-C1 [2] cycle was run with the two chemiluminescent analyzers in the $\mathrm{NO}_{\mathrm{x}}$ mode. The purpose of this test was to evaluate satisfactory agreement between the two chemiluminescent analyzers. Brake specific total $\mathrm{NO}_{\mathrm{x}}$ from the two analyzers for each mode of ISO 8178-C1 [2] cycle is shown in Table 11.

Weighted average brake specific total $\mathrm{NO}_{\mathrm{x}}$ was calculated to be 6.059 and $6.049 \mathrm{~g} / \mathrm{bhp}-\mathrm{hr}$ for analyzers 1 and 2, respectively. Continuous data from the two analyzers is shown in Figure 19. It was observed that the continuous data from the two analyzers overlapped with each other. The results obtained demonstrated a good agreement between the two analyzers.

Table 11: $\mathrm{NO}_{\mathrm{x}}$ Analyzers Correlation

\begin{tabular}{|c|c|c|c|c|c|c|c|c|}
\hline Mode & $\mathbf{1}$ & $\mathbf{2}$ & $\mathbf{3}$ & $\mathbf{4}$ & $\mathbf{5}$ & $\mathbf{6}$ & $\mathbf{7}$ & $\mathbf{8}$ (Idle) \\
\hline \multicolumn{8}{|c|}{ grams/bhp-hr } \\
\hline $\mathrm{NO}_{\mathrm{x}} 1$ & 3.07 & 3.92 & 4.79 & 9.55 & 4.77 & 5.61 & 5.92 & --- \\
\hline $\mathrm{NO}_{\mathrm{x}} 2$ & 3.05 & 3.91 & 4.79 & 9.44 & 4.78 & 5.63 & 5.92 & --- \\
\hline
\end{tabular}

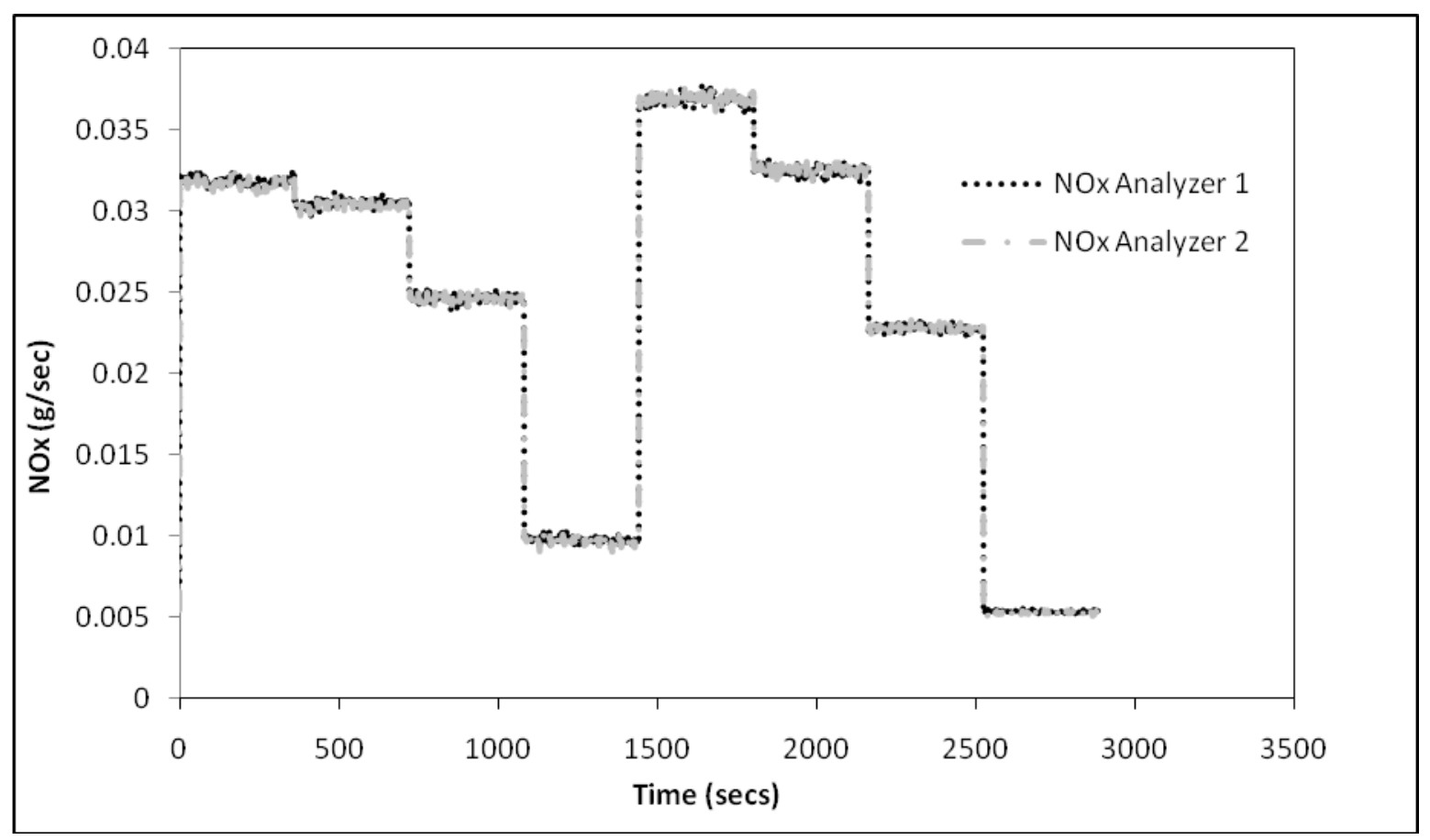

Figure 19: Continuous Data Demonstration for $\mathrm{NO}_{x}$ Analyzer Correlation 


\subsubsection{Pre-Durability Emissions Results}

\subsubsection{Engine-Out}

Prior to measuring the emissions from the filter system, the TRU engine was run under engineout (baseline) configuration and emissions were measured. Three repetitions of ISO 8178-C1 [2] cycle were performed to check the consistency. The engine speed and torque were measured for each run to demonstrate conformance to the test cycle speed and load points. The mean weighted brake specific results for all the emissions for the three repetitions of ISO 8178-C1 [2] cycle and EPA TRU [3] cycle are given in Table 12 and Table 14, respectively. The 95\% confidence interval for the three repeat runs and the error $(\%)$ are also given.

Table 12: Engine-out Weighted Brake Specific Emissions on the ISO 8178-C1 Cycle

\begin{tabular}{|c|c|c|c|}
\hline $\begin{array}{c}\text { Emission } \\
\text { Component }\end{array}$ & $\begin{array}{c}\text { Mean Brake Specific Emission } \\
(\mathrm{g} / \mathrm{bhp}-\mathrm{hr})\end{array}$ & $\begin{array}{c}95 \% \text { Confidence Margin of } \\
\text { Error }\end{array}$ & \%error \\
\hline $\mathrm{PM}$ & 0.775 & \pm 0.059 & $7.7 \%$ \\
\hline $\mathrm{HC}$ & 0.568 & \pm 0.007 & $1.3 \%$ \\
\hline $\mathrm{CO}$ & 3.91 & \pm 0.260 & $1.2 \%$ \\
\hline $\mathrm{NO}_{\mathrm{x}}$ & 4.60 & \pm 0.080 & $1.8 \%$ \\
\hline $\mathrm{NO}$ & 4.54 & \pm 0.074 & $113.1 \%$ \\
\hline $\mathrm{NO}_{2}$ & 0.065 & \pm 4.00 & $0.7 \%$ \\
\hline $\mathrm{CO}_{2}$ & 544 & \pm 0.003 & $0.7 \%$ \\
\hline bsFC (lb/bhp-hr) & 0.377 & & \\
\hline
\end{tabular}

The EPA Tier 1 emissions standards for non-road diesel engines between $25 \leq \mathrm{hp}<50$ for model year 1999-2003 are shown in Table 13. As seen in the Table 13, the test engine did not meet the Tier 1 PM emissions standards.

The EPA defines the useful life for test engines between $25 \leq \mathrm{hp}<50$ as 5000 hours or 7 years. The test engine used in this study had accumulated 12,214 hours which is well beyond the 5000 hours defined by the EPA as useful life. This explanation can be used to describe the noncompliance of the test engine with Tier 1 PM standards. 
Non-methane Hydrocarbon (NMHC) emissions were not measured separately because diesel engine exhaust consists of very low NMHC. NMHC was reported along with HC emissions.

Table 13: Comparison between EPA Tier 1 Standards for Non-Road Diesel Engines and Engine-out Results

\begin{tabular}{|c|c|c|c|}
\hline \multirow{2}{*}{} & $\begin{array}{c}\text { Tier 1 } \\
\text { Standards }\end{array}$ & Test Result & Pass/Fail \\
\cline { 2 - 4 }$(\mathrm{g} / \mathrm{bhp}-\mathrm{hr})$ & \\
\hline $\mathrm{CO}$ & 4.1 & 3.9 & Pass \\
\hline $\mathrm{PM}$ & 0.6 & 0.8 & FAIL \\
\hline NMHC $+\mathrm{NO}_{\mathrm{x}}$ & 7.1 & 5.2 & Pass \\
\hline
\end{tabular}

Table 14: Engine-out Weighted Brake Specific Emissions on EPA TRU cycle

\begin{tabular}{|c|c|c|c|}
\hline $\begin{array}{c}\text { Emission } \\
\text { Component }\end{array}$ & $\begin{array}{c}\text { Mean Brake Specific Emission } \\
(\mathrm{g} / \mathrm{bhp}-\mathrm{hr})\end{array}$ & $\begin{array}{c}\text { 95\% Confidence Margin of } \\
\text { Error }\end{array}$ & \%error \\
\hline $\mathrm{PM}$ & 0.165 & \pm 0.024 & $14.5 \%$ \\
\hline $\mathrm{HC}$ & 0.520 & \pm 0.014 & $2.8 \%$ \\
\hline $\mathrm{CO}$ & 0.796 & \pm 0.031 & $1.6 \%$ \\
\hline $\mathrm{NO}_{\mathrm{x}}$ & 4.98 & \pm 0.070 & $1.5 \%$ \\
\hline $\mathrm{NO}$ & 4.96 & \pm 0.098 & $383.1 \%$ \\
\hline $\mathrm{NO}_{2}$ & 0.026 & \pm 1.00 & $0.3 \%$ \\
\hline $\mathrm{CO}_{2}$ & 516 & \pm 0.001 & $0.2 \%$ \\
\hline $\mathrm{bsFC}(\mathrm{lb} / \mathrm{bhp}-\mathrm{hr})$ & 0.361 & & \pm 082 \\
\hline
\end{tabular}

\subsubsection{DPF/Filter-Out}

The percentage reduction in the emissions from the filter system for ISO 8178-C1 [2] cycle and EPA TRU [3] cycle is given in Table 15 and Table 17, respectively. In this case, the filter system was able to reduce PM by approximately $98 \%$ on both the test cycles. $\mathrm{HC}$ and $\mathrm{CO}$ emissions 
were reduced by $64 \%$ and $75 \%$, respectively. A slight decrease in $\mathrm{NO}_{\mathrm{x}}$ and $\mathrm{NO}$ emissions were observed. $\mathrm{CO}_{2}$ and bsFC increased moderately due to the pumping losses associated with the installation of the filter system. Mean brake specific emission, 95\% confidence margin of error and error $(\%)$ are also given.

Table 15: DPF-out Weighted Brake Specific Emissions on the ISO 8178-C1 Cycle

\begin{tabular}{|c|c|c|c|c|c|}
\hline $\begin{array}{c}\text { Emission } \\
\text { Component }\end{array}$ & $\begin{array}{c}\text { Mean Brake } \\
\text { Specific } \\
\text { Emission with } \\
\text { DPF } \\
(\mathrm{g} / \mathrm{bhp}-\mathrm{hr})\end{array}$ & $\begin{array}{c}95 \% \\
\text { Confidence } \\
\text { Margin of } \\
\text { Error }\end{array}$ & error \% & $\begin{array}{c}\text { Mean Brake } \\
\text { Specific } \\
\text { Emission } \\
\text { without DPF } \\
\text { g/bhp-hr })\end{array}$ & $\begin{array}{c}\text { Reduction } \\
\%\end{array}$ \\
\hline $\mathrm{PM}$ & 0.014 & \pm 0.002 & $17.7 \%$ & 0.775 & 98 \\
\hline $\mathrm{HC}$ & 0.138 & \pm 0.016 & $11.4 \%$ & 0.568 & 64 \\
\hline $\mathrm{CO}$ & 1.40 & \pm 0.160 & $11.4 \%$ & 3.91 & 75 \\
\hline $\mathrm{NO}_{\mathrm{x}}$ & 4.49 & \pm 0.020 & $0.4 \%$ & 4.60 & 2.4 \\
\hline $\mathrm{NO}^{\mathrm{NO}}$ & 4.23 & \pm 0.001 & $0.0 \%$ & 4.54 & 6.8 \\
\hline $\mathrm{NO}_{2}$ & 0.264 & \pm 0.017 & $6.6 \%$ & 0.065 & -306 \\
\hline $\mathrm{CO}_{2}$ & 581 & \pm 4.00 & $0.7 \%$ & 544 & -6.8 \\
\hline $\mathrm{bsFC}(\mathrm{lb} / \mathrm{bhp}-\mathrm{hr})$ & 0.400 & \pm 0.002 & $0.4 \%$ & 0.377 & -5.9 \\
\hline
\end{tabular}

The filter system consisted of a two zone catalyst. In the first zone, NO in the exhaust stream was converted to $\mathrm{NO}_{2}$ for improved oxidation of particulate matter and then excess $\mathrm{NO}_{2}$ was converted back to $\mathrm{NO}$ in the second zone. The baseline $\mathrm{NO}_{2}$ levels were extremely low resulting in large percentage increases for relatively small increases in DPF-out $\mathrm{NO}_{2}$ emissions levels.

It was shown in Table 13, that the test engine used in this study was not compliant to EPA standards for PM emissions. The EPA Tier 1 standards and the results from the filter system for the regulated emissions are given in Table 16. After installing the filter system the test engine was compliant with the EPA Tier 1 standards. 
Table 16: Comparison between EPA Tier 1 Standards for Non-Road Diesel Engines and DPF-out Results

\begin{tabular}{|c|c|c|c|}
\hline & $\begin{array}{c}\text { Tier 1 } \\
\text { Standard } \\
\end{array}$ & \multicolumn{2}{|c|}{ Test Result } \\
(g/bhp-hr $)$ & Pass/Fail \\
\hline $\mathrm{CO}$ & 4.1 & 1.40 & Pass \\
\hline $\mathrm{PM}$ & 0.6 & 0.014 & Pass \\
\hline $\mathrm{NMHC}+\mathrm{NO}_{\mathrm{x}}$ & 7.1 & 4.63 & Pass \\
\hline
\end{tabular}

Table 17: DPF-out Weighted Brake Specific Emissions on the EPA TRU Cycle

\begin{tabular}{|c|c|c|c|c|c|}
\hline $\begin{array}{c}\text { Emission } \\
\text { Component }\end{array}$ & $\begin{array}{c}\text { Mean Brake } \\
\text { Specific } \\
\text { Emission with } \\
\text { DPF } \\
\text { (g/bhp-hr) }\end{array}$ & $\begin{array}{c}\text { 95\% } \\
\text { Confidence } \\
\text { Margin of } \\
\text { Error }\end{array}$ & $\begin{array}{c}\text { error } \\
\%\end{array}$ & $\begin{array}{c}\text { Mean Brake } \\
\text { Specific Emission } \\
\text { without DPF } \\
\text { (g/bhp-hr) }\end{array}$ & $\begin{array}{c}\text { Reduction } \\
\%\end{array}$ \\
\hline $\mathrm{PM}$ & 0.004 & \pm 0.001 & $39.1 \%$ & 0.165 & 98 \\
\hline $\mathrm{HC}$ & 0.073 & \pm 0.005 & $6.8 \%$ & 0.520 & 77 \\
\hline $\mathrm{CO}$ & 0.180 & \pm 0.011 & $4.8 \%$ & 0.796 & 86 \\
\hline $\mathrm{NO}_{\mathrm{x}}$ & 4.81 & \pm 0.030 & $0.6 \%$ & 4.98 & 3.5 \\
\hline $\mathrm{NO}$ & 4.33 & \pm 0.011 & $0.2 \%$ & 4.96 & 13 \\
\hline $\mathrm{NO}_{2}$ & 0.479 & \pm 0.030 & $6.2 \%$ & 0.026 & -1759 \\
\hline $\mathrm{CO}_{2}$ & 541 & \pm 2.00 & $0.5 \%$ & 516 & -4.8 \\
\hline $\mathrm{bsFC}(\mathrm{lb} / \mathrm{bhp}-\mathrm{hr})$ & 0.377 & \pm 0.002 & $0.5 \%$ & 0.361 & -4.4 \\
\hline
\end{tabular}

\subsubsection{Compliance with $\mathrm{NO}_{2}$ Emission Limits}

CARB regulations require that the increase in $\mathrm{NO}_{2}$ produced by the after-treatment control system must not exceed $20 \%$ of the baseline $\mathrm{NO}_{\mathrm{x}}$ emissions level. The final average incremental increase in $\mathrm{NO}_{2}$ emission was determined by using the following equation: 
PercentI ncrease $=\frac{100 \% \times 0.5 \times\left[\left(\mathrm{NO}_{2}^{i}-\mathrm{NO}_{2}^{b}\right)+\left(\mathrm{NO}_{2}^{f}-\mathrm{NO}_{2}^{b}\right)\right]}{\mathrm{NO} x^{b}}$

Where,

" $\mathrm{NO}_{2}$ " and " $\mathrm{NO}_{\mathrm{x}}$ " stand for the mass-based emission rates of $\mathrm{NO}_{2}$ and $\mathrm{NO}_{\mathrm{x}}$, and subscript "i", "f" and "b" refer to "pre-durability/initial", "post-durability/final" and "baseline" tests respectively.

Considering the pre-durability testing (single testing) the above equation reduces to:

Percent Increase $=\frac{100 \% \times\left[\left(\mathrm{N}_{2}^{i}-\mathrm{N}_{2}^{b}\right)\right]}{\operatorname{No} x^{b}}$

(Equation 19)

For ISO 8178-C1 [2] cycle, from Table 12 and Table 15:

$\mathrm{NO}_{2}^{i}=0.264, \mathrm{NO}_{2}^{b}=0.065$ and $\mathrm{NOx}^{b}=4.60$

Therefore, Percent Increase $=\frac{100 \% \times[(0.264-0.065)]}{4.60}=4.33 \%$

For EPA TRU cycle, from Table 14 and Table 17:

$\mathrm{NO}_{2}^{i}=0.479, \mathrm{NO}_{2}^{b}=0.026$ and $\mathrm{NOx}^{b}=4.98$

Therefore, $\quad$ Percent Increase $=\frac{100 \% \times[(0.479-0.026)]}{4.98}=9.09 \%$

For ISO 8178-C1 [2] cycle and EPA TRU [3] cycle, $\mathrm{NO}_{2}$ emission levels increased by $4.33 \%$ and $9.09 \%$, respectively. The results complied with the maximum increase of $20 \%$ in $\mathrm{NO}_{2}$ levels as required by CARB. The pre-durability testing $\mathrm{NO}_{2}$ compliance value (average of ISO 8178 $\mathrm{C} 1$ cycle and EPA TRU test cycles) was $6.71 \% \pm 1.60 \%$ of total $\mathrm{NO}_{\mathrm{x}}$, which satisfied the maximum permissible limit of $20 \%$ for verification. 


\subsubsection{Exhaust Backpressure and Temperatures During The Test Cycle}

The average exhaust backpressures measured during the three ISO 8178-C1 [2] cycles under baseline and DPF-out testing conditions are shown in Figure 20 and Figure 21, respectively. It was observed that the exhaust backpressure decreased subsequently over the 8 modes of ISO 8178-C1 [2] cycle. In the baseline testing, a baffle valve was used to set the exhaust backpressure at $10 \mathrm{kPa}$ gage as recommended by the manufacturer. The Baffle valve was fully opened in the case of DPF-out testing so as not to add additional backpressure. The backpressure seen in Figure 21 was a result of installation of the particulate filter system.

The average exhaust pre and post-filter temperature measured during the three repetitions of ISO 8178-C1 [2] cycle is shown in Figure 22. The post-filter temperature was observed to be lower than the pre-filter temperature for almost all the modes of ISO 8178-C1 [2] cycle.

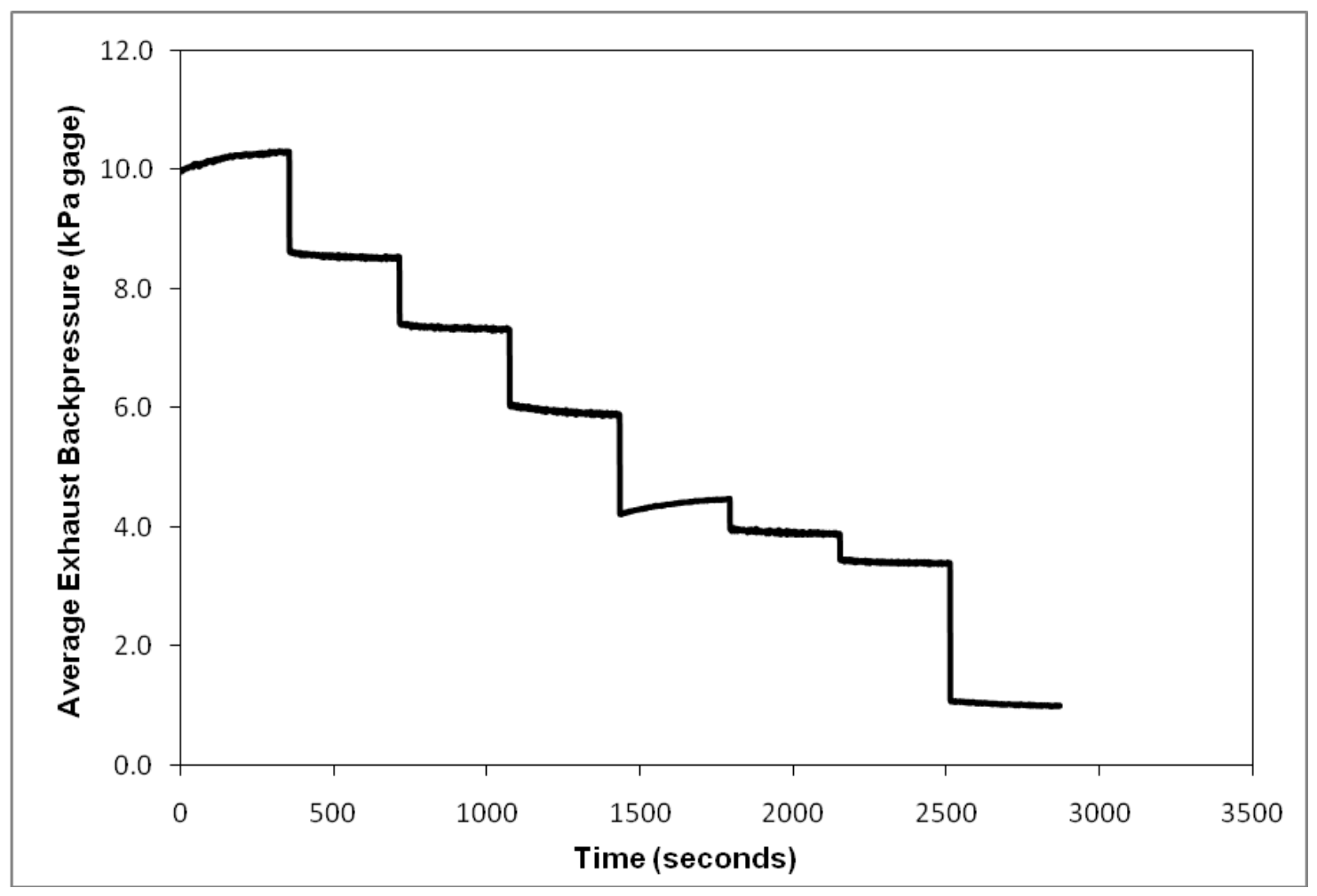

Figure 20: Average Exhaust Backpressure Measured During Baseline Testing 


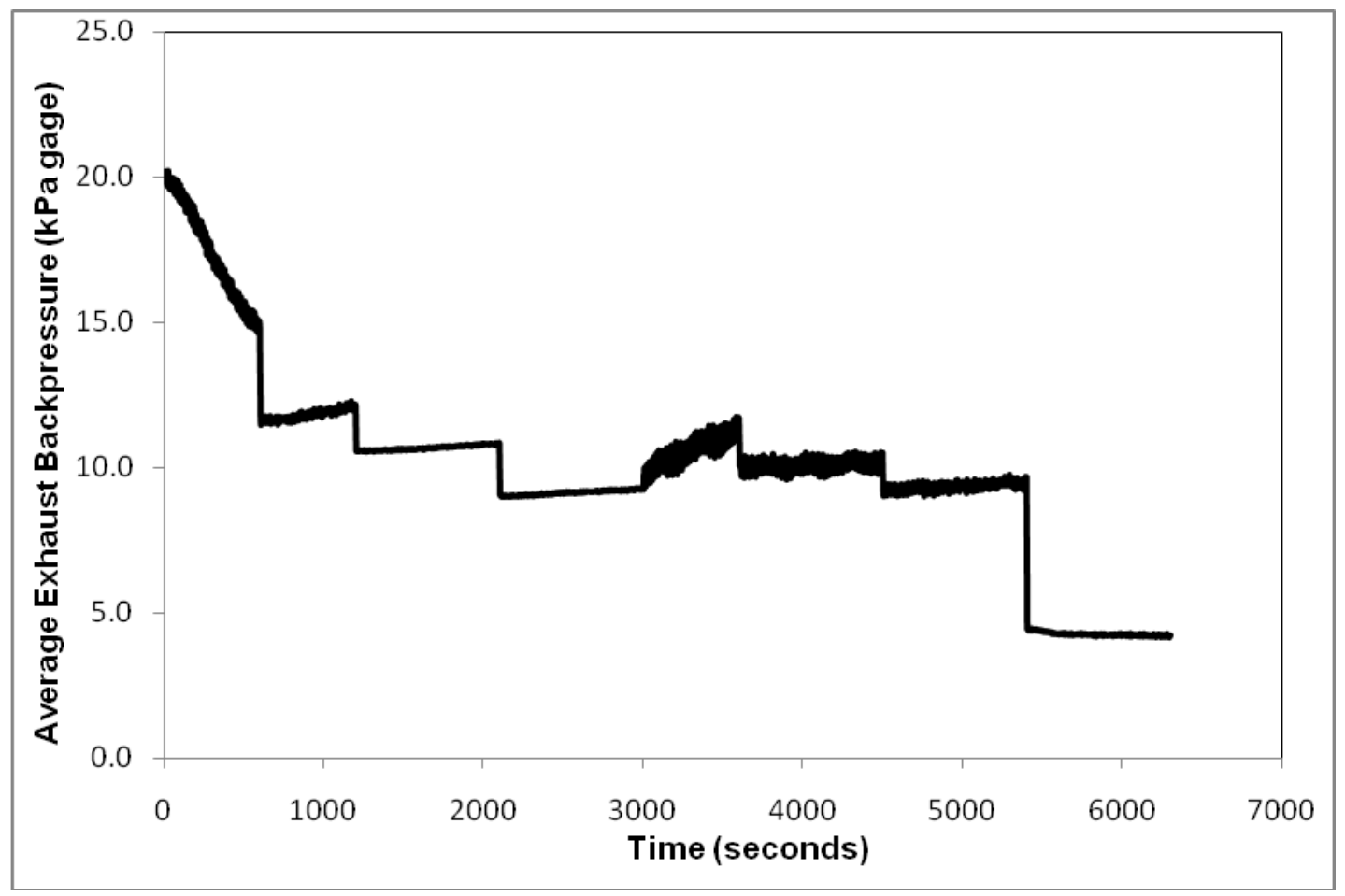

Figure 21: Average Exhaust Backpressure Measured During DPF-out Testing

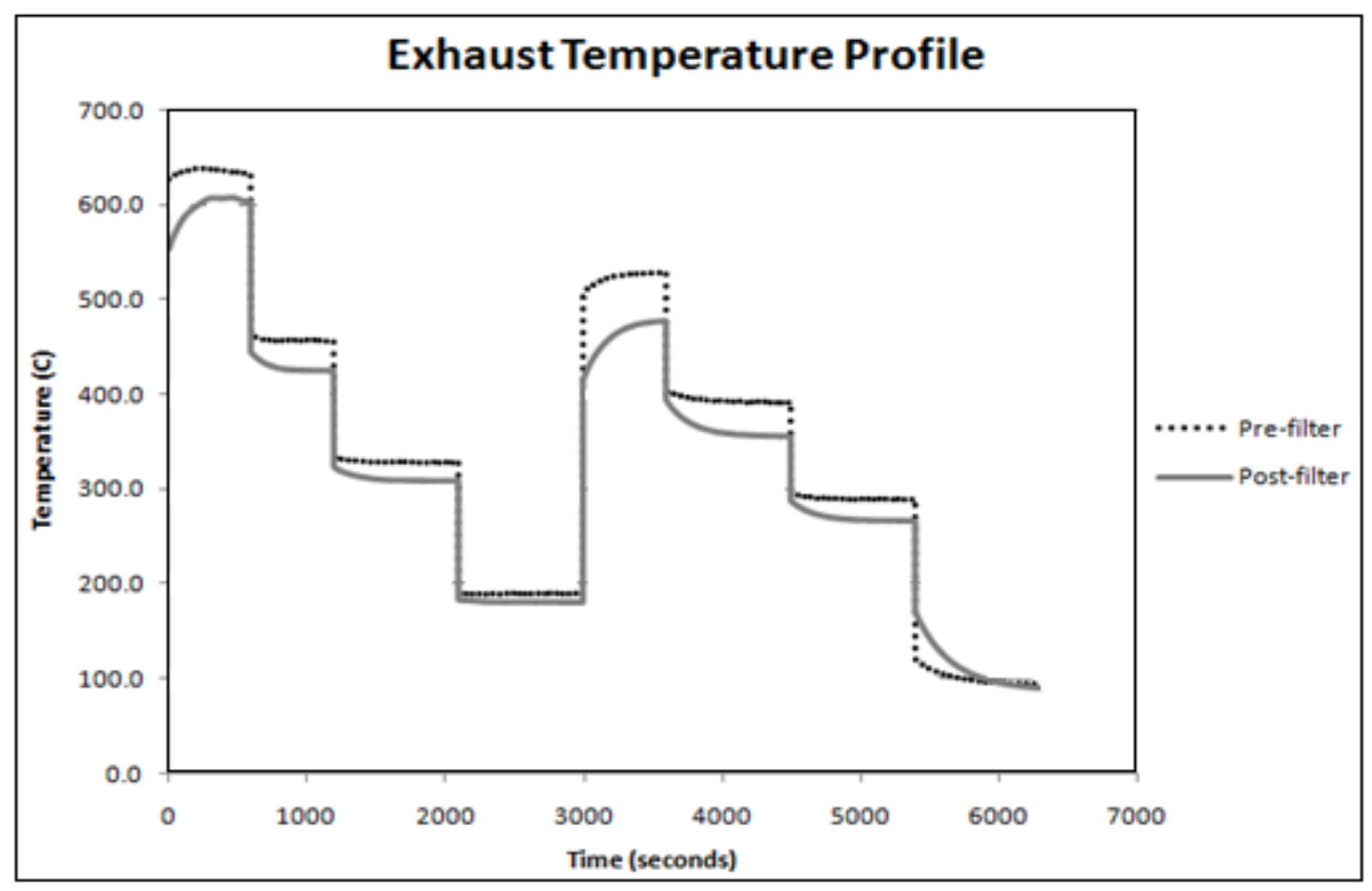

Figure 22: Average Exhaust Pre and Post-filter Temperatures 


\subsection{Post-Durability Emissions Testing}

\subsubsection{Compliance with 30\% Increase in Initial Exhaust Backpressure}

The initial backpressure for the last three hours of the de-greening process for the pre-durability testing was given in Table 7. CARB regulations require that the backpressure with the aged filter (1000 hours in-field testing) must not exceed 30\% of the initial backpressure when the filter system was new. The exhaust backpressure recorded during the post-durability testing and the percentage increase in the exhaust backpressure from the pre-durability is given in Table 18. The aged filter system met the backpressure requirements set by CARB.

\section{Table 18: Pre and Post-Durability Exhaust Backpressures}

\begin{tabular}{|c|c|c|c|c|}
\hline Mode & Mode 1 & Mode 2 & Mode 3 & Mode 4 \\
\hline Pre-Durability & 40.6 & 39.2 & 29.1 & 27.1 \\
\hline Post-Durability & 46.4 & 44.6 & 30.9 & 28.6 \\
\hline Percent Increase & $13.9 \%$ & $13.7 \%$ & $6.2 \%$ & $5.2 \%$ \\
\hline
\end{tabular}

\subsubsection{Engine Lug Curve}

Engine warming was followed by full power lug curves to determine the ISO 8178-C1 speed/torque set points. Engine mapping was performed similar to the pre-durability testing. Three lug curves were performed to check the consistency. The average results from the three lug curves are shown in Figure 23. Engine performance indicated by the peak power of $33.4 \mathrm{hp}$ @ 2173 rpm and peak torque of $91 \mathrm{ft}-1 \mathrm{~b} @ 1385 \mathrm{rpm}$ were slightly lower than observed during the pre-durability testing. These performance measures were in agreement with the manufacturer's performance specifications shown in Table 6 . 


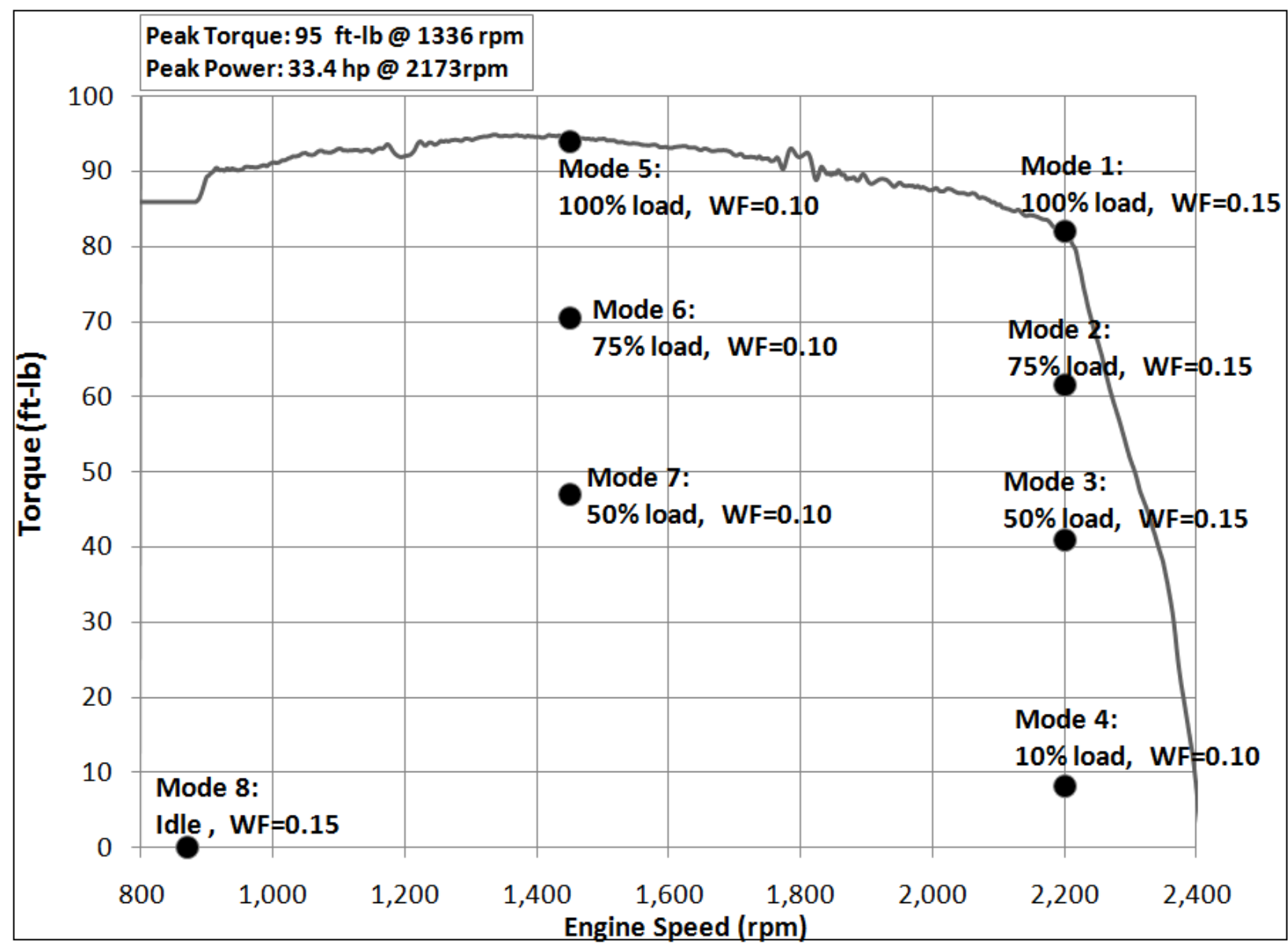

Figure 23: Post-durability Lug Curve

\subsubsection{Emissions Test Cycle}

Emissions were collected from the ISO 8178-C1 [2] cycle set points shown in Table 19 determined from the lug curve shown in Figure 23. It is to be noted that the torque set points in post-durability testing were slightly lower than pre-durability testing values. 
Table 19: ISO 8178-C1 Test Cycle with Performance Specifications for Post-Durability Testing

\begin{tabular}{|c|c|c|c|c|c|c|c|c|}
\hline Mode & 1 & 2 & 3 & 4 & 5 & 6 & 7 & 8 \\
\hline Weighting Factor & 0.15 & 0.15 & 0.15 & 0.10 & 0.10 & 0.10 & 0.10 & 0.15 \\
\hline Speed & \multicolumn{4}{|c|}{ Rated Speed } & \multicolumn{3}{|c|}{ Intermediate Speed } & Idle \\
\hline (rpm) & \multicolumn{4}{|c|}{$(2200)$} & \multicolumn{3}{|c|}{ (1450) } & (870) \\
\hline Torque, $\%$ & 100 & 75 & 50 & 10 & 100 & 75 & 50 & - \\
\hline (ft-lb) & (80) & (60) & (41) & (8.8) & (90) & (69) & (46) & - \\
\hline
\end{tabular}

Table 20: EPA TRU Test Cycle with Performance Specifications for Post-Durability Testing

\begin{tabular}{|c|c|c|c|c|c|c|c|c|}
\hline Mode & 1 & 2 & 3 & 4 & 5 & 6 & 7 & 8 \\
\hline Weighting Factor & & 0.25 & 0.25 & & & 0.25 & 0.25 & \\
\hline Speed & \multicolumn{4}{|c|}{ Rated Speed } & \multicolumn{3}{|c|}{ Intermediate Speed } & Idle \\
\hline$(\mathrm{rpm})$ & \multicolumn{4}{|c|}{ (2200) } & \multicolumn{3}{|c|}{$(1450)$} & (870) \\
\hline Torque, $\%$ & - & 75 & 50 & - & - & 75 & 50 & - \\
\hline (ft-lb) & - & (60) & (41) & - & - & (69) & (46) & - \\
\hline
\end{tabular}

\subsubsection{Test Fuel Analysis}

Upon the request of CARB, extra tests were performed to confirm the engine-out $\mathrm{NO}_{2}$ levels in the pre-durability and post-durability testing. As a result of these extra tests, sufficient amount of fuel was not available to perform three baseline and DPF-out emissions in post-durability testing as planned. A second batch of fuel with the same specifications as the original fuel was procured. The specifications of the new test fuel are shown in Table 21. 
Table 21: New Fuel Analysis Results

\begin{tabular}{|c|c|c|c|c|}
\hline Property, Units - ASTM Method & $\begin{array}{c}\text { Replicate No. } \\
1\end{array}$ & $\begin{array}{c}\text { Replicate No. } \\
2\end{array}$ & $\begin{array}{c}\text { Replicate No. } \\
3\end{array}$ & Average \\
\hline Distillation, F- D86 & & & & \\
\hline Initial Boiling Point & 373 & 371 & 373 & 372 \\
\hline$-10 \%$ & 409 & 407 & 407 & 386 \\
\hline Recovered -50\% & 493 & 492 & 494 & 493 \\
\hline Final Boiling Point & 611 & 610 & 612 & 611 \\
\hline Viscosity @ 40 C, cSt - D445 & 661 & 657 & 660 & 659 \\
\hline Sulfur Content, ppm - D5453 & 6.456 & 2.456 & 2.454 & 2.455 \\
\hline Aromatics, wt \% - D5186 & & 6.1 & 6.59 & 6.23 \\
\hline Mono-aromatics & 16.9 & 16.9 & 16.8 & 16.8 \\
\hline Poly-nuclear aromatics & 6.8 & 6.8 & 7.0 & 6.9 \\
\hline Total aromatics & 23.7 & 23.7 & 23.8 & 23.7 \\
\hline API Gravity, deg API- & 39.1 & 39.1 & 39.1 & 39.1 \\
\hline D287/D1298 & 53.8 & 54.0 & 53.8 & 53.9 \\
\hline Cetane Number - D613 & 165 & 164 & 164 & 164 \\
\hline Flashpoint PMCC, F - D93 & 38 & 37 & 38 & 38 \\
\hline Nitrogen, mg/kg - D4629 & & & & \\
\hline
\end{tabular}

\subsection{4 $\mathrm{NO}_{\mathrm{x}}$ Analyzer Correlation Test}

Prior to starting the post-durability emissions testing, the two $\mathrm{NO}_{\mathrm{x}}$ analyzers were verified for satisfactory agreement with each other. The two $\mathrm{NO}_{\mathrm{x}}$ analyzers were set in $\mathrm{NO}_{\mathrm{x}}$ mode and then in NO mode and engine-out emissions on ISO 8178-C1 [2] cycle were collected. The results from the two analyzers in units of grams/bhp-hr for each mode of ISO 8178-C1 [2] cycle are given in Table 22. The results from the two analyzers show that the coefficient of variance (COV) was less than $1.5 \%$ which demonstrates that the two analyzers were in good agreement during both $\mathrm{NO}_{\mathrm{x}}$ and $\mathrm{NO}$ mode. 
Table 22: $\mathrm{NO}_{\mathrm{x}}$ Analyzers Correlation

\begin{tabular}{|c|c|c|c|c|c|c|c|c|c|}
\hline Mode & 1 & 2 & 3 & 4 & 5 & 6 & 7 & 8 \\
\hline \multicolumn{7}{|c|}{$\mathrm{NO}_{\mathrm{x}}$ mode (g/bhp-hr) } \\
\hline $\mathrm{NO}_{\mathrm{x}}$ Analyzer 1 & 3.21 & 4.02 & 4.75 & 8.89 & 4.89 & 5.66 & 5.79 & -- \\
\hline $\mathrm{NO}_{\mathrm{x}}$ Analyzer 2 & 3.18 & 4.08 & 4.81 & 9.07 & 4.94 & 5.73 & 5.88 & -- \\
\hline $\mathrm{COV}(\%)$ & 0.66 & 1.05 & 0.89 & 1.42 & 0.72 & 0.87 & 1.09 & -- \\
\hline \multicolumn{7}{|c|}{ NO mode (g/bhp-hr) } \\
\hline $\mathrm{NO}_{\mathrm{x}}$ Analyzer 1 & 3.12 & 3.99 & 4.71 & 8.31 & 4.86 & 5.68 & 5.83 & -- \\
\hline $\mathrm{NO}_{\mathrm{x}}$ Analyzer 2 & 3.14 & 4.01 & 4.74 & 8.37 & 4.88 & 5.70 & 5.86 & -- \\
\hline $\mathrm{COV}(\%)$ & 0.45 & 0.35 & 0.45 & 0.51 & 0.29 & 0.25 & 0.36 & -- \\
\hline
\end{tabular}

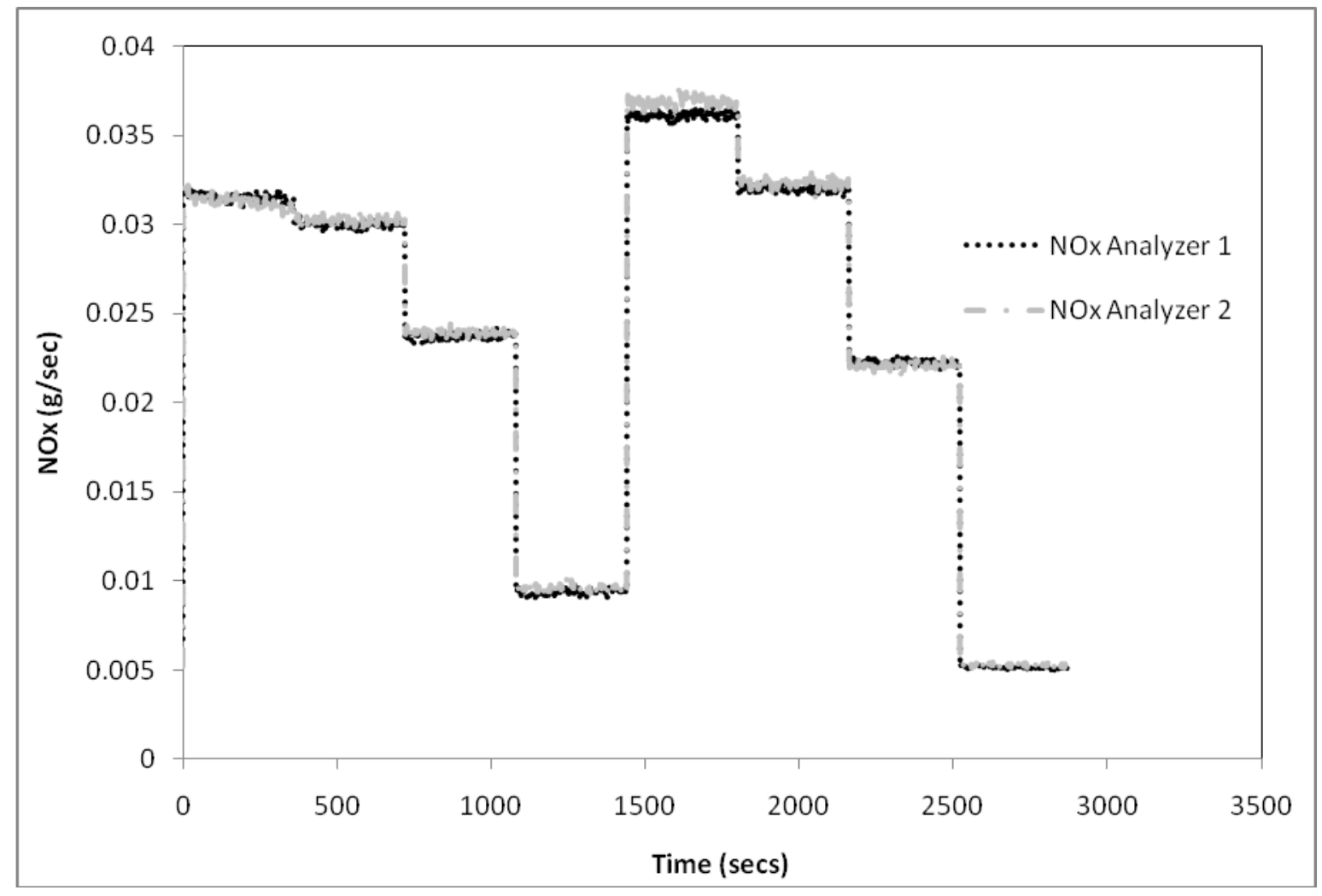

Figure 24: Continuous Data Demonstration for $\mathrm{NO}_{x}$ Analyzer Correlation (both in $\mathrm{NO}_{x}$ mode) 


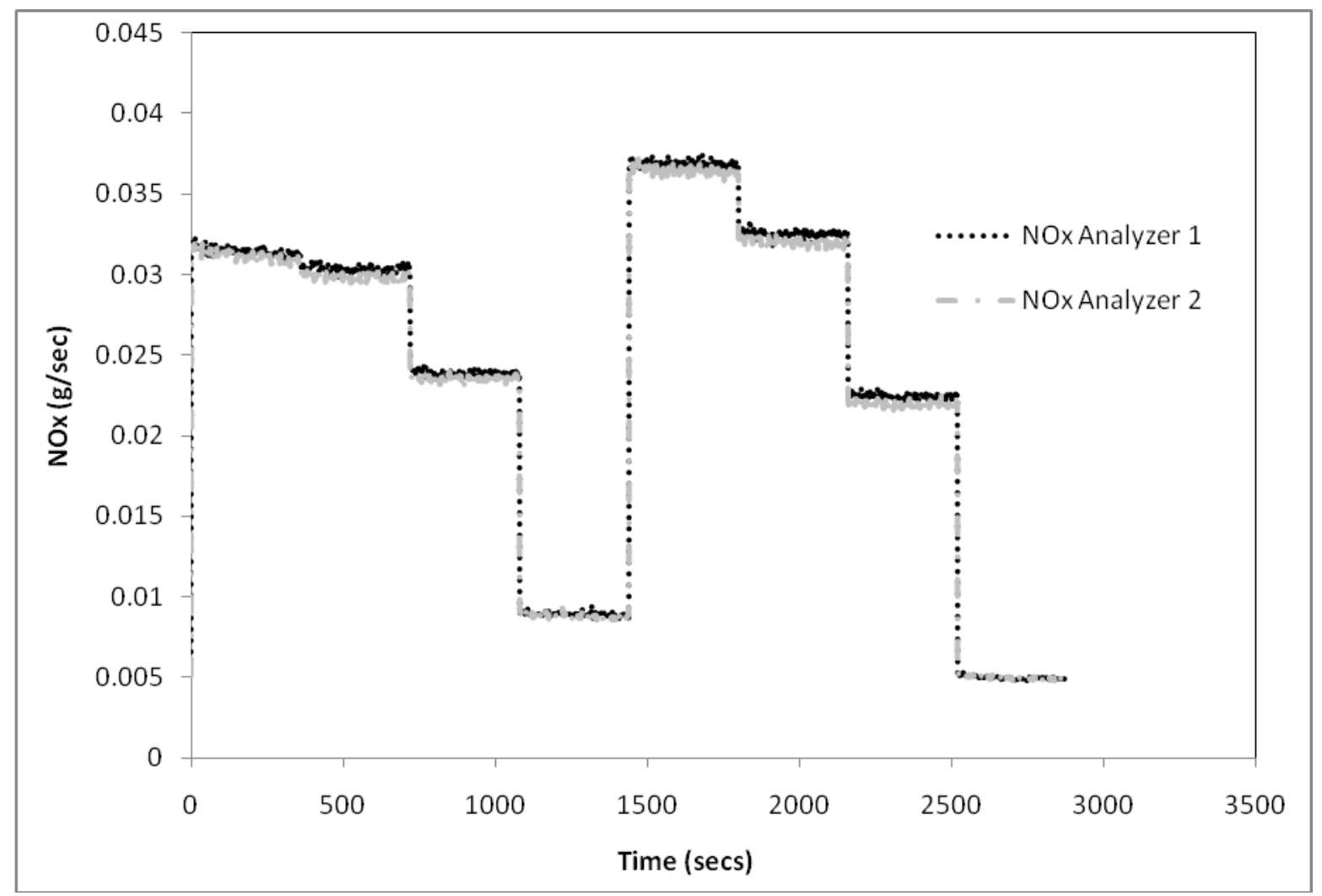

Figure 25: Continuous Data Demonstration for $\mathrm{NO}_{x}$ Analyzer Correlation (both in NO mode)

\subsubsection{Post-Durability Emissions Results}

\subsubsection{Engine Out}

Three repeats of the ISO 8178-C1 [2] test cycle under baseline conditions were performed for consistency. The average brake specific emissions calculated for the ISO 8178-C1 [2] and EPA TRU [3] test cycle are given in Table 23 and Table 25, respectively. Error bounds representing the $95 \%$ confidence and the error $(\%)$ are also given. The test results are compared to EPA Tier 1 standards in Table 24. The CO and PM emissions from the test engine did not satisfy the EPA Tier 1 standards under baseline conditions. 
Table 23: Baseline Weighted Brake Specific Emissions on ISO 8178-C1 Cycle

\begin{tabular}{|c|c|c|c|}
\hline $\begin{array}{c}\text { Emission } \\
\text { Component }\end{array}$ & $\begin{array}{c}\text { Mean Brake Specific Emission } \\
\text { (g/bhp-hr) }\end{array}$ & $\begin{array}{c}\text { 95\% Confidence Margin of } \\
\text { Error }\end{array}$ & $\begin{array}{c}\text { error } \\
\%\end{array}$ \\
\hline $\mathrm{PM}$ & 0.814 & \pm 0.044 & $5.4 \%$ \\
\hline $\mathrm{HC}$ & 0.532 & \pm 0.095 & $17.8 \%$ \\
\hline $\mathrm{CO}$ & 4.25 & \pm 0.290 & $6.8 \%$ \\
\hline $\mathrm{NO}_{\mathrm{x}}$ & 4.64 & \pm 0.110 & $2.3 \%$ \\
\hline $\mathrm{NO}$ & 4.57 & \pm 0.081 & $1.7 \%$ \\
\hline $\mathrm{NO}_{2}$ & 0.078 & \pm 0.031 & $39.4 \%$ \\
\hline $\mathrm{CO}_{2}$ & 550 & \pm 2.00 & $0.5 \%$ \\
\hline $\mathrm{bsFC}(\mathrm{lb} / \mathrm{bhp}-\mathrm{hr})$ & 0.382 & \pm 0.001 & $0.2 \%$ \\
\hline
\end{tabular}

Table 24: EPA Tier 1 Emissions Standard for Non-Road Diesel Engines

\begin{tabular}{|c|c|c|c|}
\hline \multirow{2}{*}{} & \multicolumn{2}{|c|}{$\begin{array}{c}\text { Standard } \\
\text { (g/bhp-hr) }\end{array}$} & Test Result \\
\cline { 2 - 3 } & Pass/Fail \\
\hline $\mathrm{CO}$ & 4.1 & 4.25 & FAIL \\
\hline $\mathrm{PM}$ & 0.6 & 0.814 & FAIL \\
\hline NMHC + $\mathrm{NO}_{\mathrm{x}}$ & 7.1 & 5.17 & Pass \\
\hline
\end{tabular}


Table 25: Baseline Weighted Brake Specific Emissions on the EPA TRU Test Cycle

\begin{tabular}{|c|c|c|c|}
\hline $\begin{array}{c}\text { Emission } \\
\text { Component }\end{array}$ & $\begin{array}{c}\text { Mean Brake Specific Emission } \\
\text { (g/bhp-hr) }\end{array}$ & $\begin{array}{c}95 \% \text { Confidence Margin of } \\
\text { Error }\end{array}$ & $\begin{array}{c}\text { error } \\
\%\end{array}$ \\
\hline $\mathrm{PM}$ & 0.131 & \pm 0.007 & $5.5 \%$ \\
\hline $\mathrm{HC}$ & 0.412 & \pm 0.068 & $16.4 \%$ \\
\hline $\mathrm{CO}$ & 0.755 & \pm 0.040 & $4.8 \%$ \\
\hline $\mathrm{NO}_{\mathrm{x}}$ & 5.05 & \pm 0.121 & $2.4 \%$ \\
\hline $\mathrm{NO}$ & 4.98 & \pm 0.092 & $42.8 \%$ \\
\hline $\mathrm{NO}_{2}$ & 0.066 & \pm 1.00 & $0.3 \%$ \\
\hline $\mathrm{CO}_{2}$ & 519 & \pm 0.001 & $0.3 \%$ \\
\hline $\mathrm{bsFC}(\mathrm{lb} / \mathrm{bhp}-\mathrm{hr})$ & 0.363 & & \\
\hline
\end{tabular}

\subsubsection{DPF-Out}

The percentage reduction in the emissions from the filter system for ISO 8178-C1 [2] cycle and EPA TRU [3] cycle is given in Table 26 and Table 28, respectively. In this case, the filter system was able to reduce PM by $87 \%$ in both test cycles. $\mathrm{HC}$ and $\mathrm{CO}$ emissions were reduced by $78 \%$ and $80 \%$, respectively. A slight decrease in $\mathrm{NO}_{\mathrm{x}}$ and $\mathrm{NO}$ emissions were observed. $\mathrm{CO}_{2}$ and bsFC increased moderately due to the pumping losses associated with the installation of the filter system. Mean brake specific emission, $95 \%$ confidence margin of error and error (\%) are also given. 
Table 26: DPF-out Weighted Brake Specific Emissions on the ISO 8178-C1 Cycle

\begin{tabular}{|c|c|c|c|c|c|}
\hline $\begin{array}{c}\text { Emission } \\
\text { Component }\end{array}$ & $\begin{array}{c}\text { Mean Brake } \\
\text { Specific Emission } \\
\text { with DPF } \\
\text { (g/bhp-hr) }\end{array}$ & $\begin{array}{c}95 \% \\
\text { Confidence } \\
\text { Margin of } \\
\text { Error }\end{array}$ & error \% & $\begin{array}{c}\text { Mean Brake } \\
\text { Specific } \\
\text { Emission } \\
\text { without DPF } \\
\text { (g/bhp-hr })\end{array}$ & $\begin{array}{c}\text { Reduction } \\
\%\end{array}$ \\
\hline $\mathrm{PM}$ & 0.042 & \pm 0.011 & $26.9 \%$ & 0.814 & 95 \\
\hline $\mathrm{HC}$ & 0.118 & \pm 0.026 & $22.4 \%$ & 0.532 & 78 \\
\hline $\mathrm{CO}$ & 0.840 & \pm 0.281 & $33.6 \%$ & 4.25 & 40 \\
\hline $\mathrm{NO}$ & 4.42 & \pm 0.161 & $3.6 \%$ & 4.64 & 7.6 \\
\hline $\mathrm{NO}_{\mathrm{x}}$ & 4.22 & \pm 0.202 & $4.7 \%$ & 4.57 & -158 \\
\hline $\mathrm{NO}_{2}$ & 0.202 & \pm 0.053 & $26.0 \%$ & 0.078 & 0.7 \\
\hline $\mathrm{CO}_{2}$ & 546 & \pm 11.0 & $2.0 \%$ & 550 & 1.5 \\
\hline $\mathrm{bsFC}(\mathrm{lb} / \mathrm{bhp}-\mathrm{hr})$ & 0.376 & \pm 0.002 & $0.5 \%$ & 0.382 & 40 \\
\hline
\end{tabular}

It was shown in Table 24 that the test engine used in this study was not compliant to EPA standards for PM emissions. The EPA Tier 1 standards and the results from the filter system for the regulated emissions are given in Table 27. After installing the filter system the test engine was compliant with the EPA Tier 1 standards.

Table 27: EPA Tier 1 Standards for Non-Road Diesel Engines

\begin{tabular}{|c|c|c|c|}
\hline & Standard & Test Result & \multirow[t]{2}{*}{ Pass/Fail } \\
\hline & \multicolumn{2}{|c|}{ (g/bhp-hr) } & \\
\hline $\mathrm{CO}$ & 4.1 & 0.841 & Pass \\
\hline PM & 0.6 & 0.042 & Pass \\
\hline $\mathrm{NMHC}+\mathrm{NO}_{\mathrm{x}}$ & 7.1 & 4.538 & Pass \\
\hline
\end{tabular}


Table 28: DPF-out Weighted Brake Specific Emissions on the EPA TRU Test Cycle

\begin{tabular}{|c|c|c|c|c|c|}
\hline $\begin{array}{c}\text { Emission } \\
\text { Component }\end{array}$ & $\begin{array}{c}\text { Mean Brake } \\
\text { Specific Emission } \\
\text { with DPF } \\
\text { (g/bhp-hr) }\end{array}$ & $\begin{array}{c}95 \% \\
\text { Confidence } \\
\text { Margin of } \\
\text { Error }\end{array}$ & error \% & $\begin{array}{c}\text { Mean Brake } \\
\text { Specific Emission } \\
\text { without DPF } \\
\text { (g/bhp-hr) }\end{array}$ & $\begin{array}{c}\text { Reduction } \\
\%\end{array}$ \\
\hline $\mathrm{PM}$ & 0.017 & \pm 0.018 & $101.7 \%$ & 0.131 & 87 \\
\hline $\mathrm{HC}$ & 0.052 & \pm 0.015 & $27.8 \%$ & 0.412 & 79 \\
\hline $\mathrm{CO}$ & 0.157 & \pm 0.019 & $11.9 \%$ & 0.755 & 5.4 \\
\hline $\mathrm{NO}{ }_{\mathrm{x}}$ & 4.78 & \pm 0.178 & $3.7 \%$ & 5.05 & 11 \\
\hline $\mathrm{NO}^{\mathrm{NO}}$ & 4.44 & \pm 0.240 & $5.5 \%$ & 4.98 & -405 \\
\hline $\mathrm{NO}_{2}$ & 0.333 & \pm 0.076 & $22.7 \%$ & 0.066 & 1.7 \\
\hline $\mathrm{CO}_{2}$ & 510 & \pm 7.00 & $1.4 \%$ & 519 & 2.1 \\
\hline $\mathrm{bsFC}(\mathrm{lb} / \mathrm{bhp}-\mathrm{hr})$ & 0.355 & \pm 0.004 & $1.2 \%$ & 0.363 & 87 \\
\hline
\end{tabular}

\subsubsection{Compliance with $\mathrm{NO}_{2}$ Emission Limits}

Equation 19 was used to calculate the percentage increase in $\mathrm{NO}_{2}$ emission level in the postdurability testing (single testing).

For ISO 8178-C1 [2] cycle, from Table 23 and Table 26:

$\mathrm{NO}_{2}^{i}=0.202, \mathrm{NO}_{2}^{b}=0.078$ and $\mathrm{NOx}^{b}=4.64$

Therefore, Percent Increase $=\frac{100 \% \times[(0.202-0.078)]}{4.64}=2.67 \%$

For EPA TRU cycle, from Table 25 and Table 28:

$\mathrm{NO}_{2}^{i}=0.333, \mathrm{NO}_{2}^{b}=0.066$ and $\mathrm{NOx}^{b}=5.05$

Therefore, Percent Increase $=\frac{100 \% \times[(0.333-0.066)]}{5.05}=5.29 \%$

For ISO 8178-C1 [2] cycle and EPA TRU [3] cycle, $\mathrm{NO}_{2}$ emission levels increased by $2.67 \%$ and $5.29 \%$, respectively. The results complied with the maximum increase of $20 \%$ in $\mathrm{NO}_{2}$ levels as required by CARB. The $\mathrm{NO}_{2}$ compliance value (average of ISO 8178-C1 [2] cycle and EPA 
TRU [3] cycle) increased by $3.25 \% \pm 5.53 \%$ over the baseline engine-out levels for the postdurability testing.

\subsection{Results and Discussion}

Once the data was collected from the baseline and DPF-out emissions testing, they were reduced for further data analyses. All the data collected was reduced to the same units with time in seconds, engine speed in revolutions per minute and engine torques in foot-pounds.

The weighted brake specific emissions (g/bhp-hr) for all the regulated components have been averaged and shown in Figure 26 through Figure 33 for PM, $\mathrm{HC}, \mathrm{CO}, \mathrm{NO}_{\mathrm{x}}, \mathrm{NO}, \mathrm{CO}_{2}$ and fuel consumption (bsFC in lb/bhp-hr), respectively. The graphs represents pre-durability baseline, pre-durability DPF-out, post-durability baseline and post-durability DPF-out emission results for ISO 8178-C1 [2] and EPA TRU [3] test cycle, respectively. The error bars correspond to the 95\% confidence intervals. The margins of error could have been reduced by increasing the number of tests but conventionally 3 repeats have been used taking the available funding into consideration. 


\subsubsection{PM Emission}

The average brake specific PM emission (g/bhp-hr) for the pre-durability and post-durability testing from ISO 8178-C1 [2] and EPA TRU [3] test cycle is shown in Figure 26. PM emission was reduced by more than $95 \%$ in ISO $8178-\mathrm{C} 1$ [2] cycle and $87 \%$ in EPA TRU [3] cycle, respectively. Statistical approach was used to calculate the $95 \%$ confidence error in the three repeats represented by the error bars.

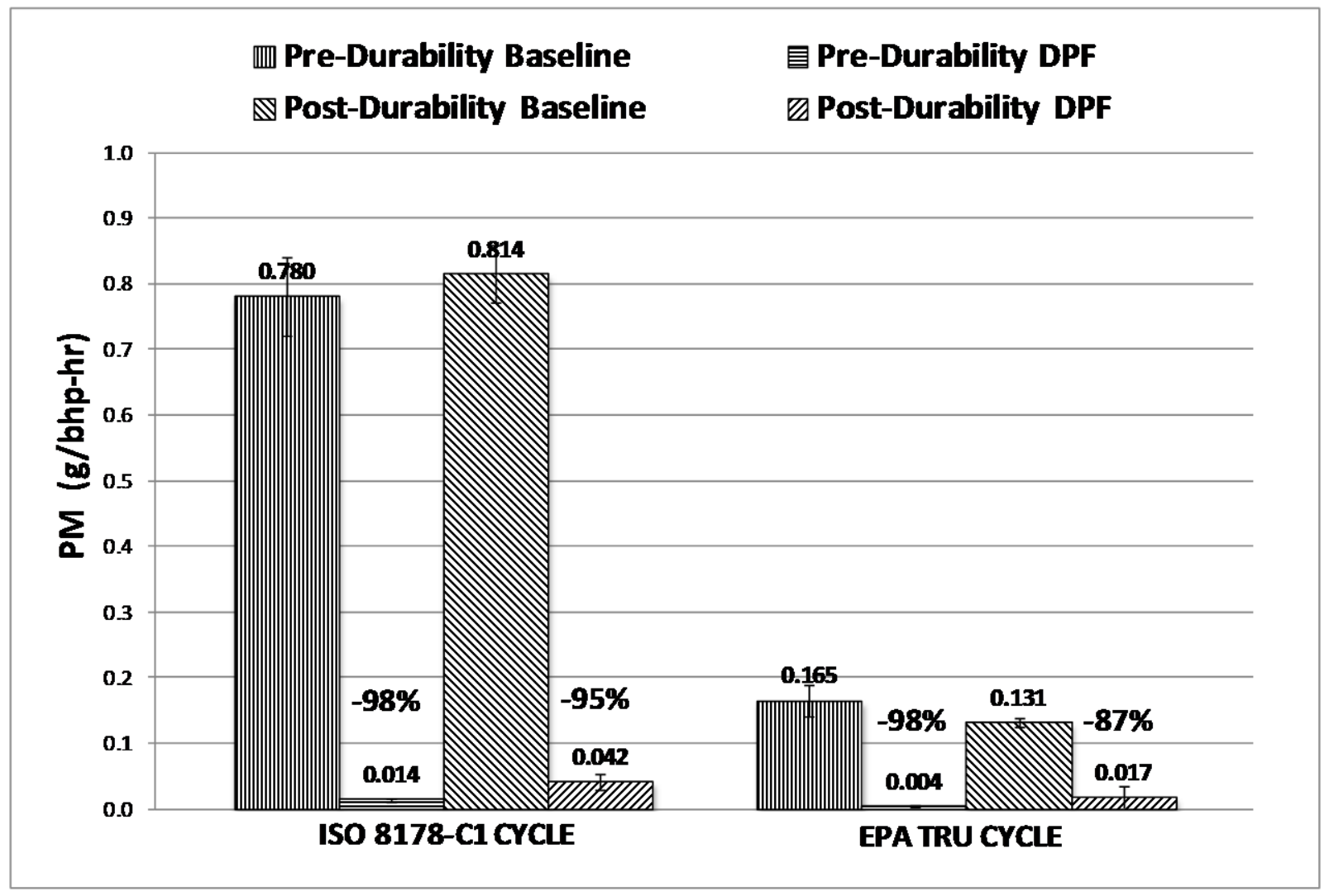

Figure 26: Weighted Brake Specific Particulate Matter (g/bhp-hr) 


\subsubsection{HC Emission}

Average Results for all the emissions testing are shown in Figure 27. Filter system reduced HC emission by more than $76 \%$ in ISO $8178-\mathrm{C} 1$ [2] cycle and $86 \%$ in EPA TRU [3] cycle, respectively. The $\mathrm{HC}$ emission for the first run of the three repeats for post-durability testing was low resulting in large error.

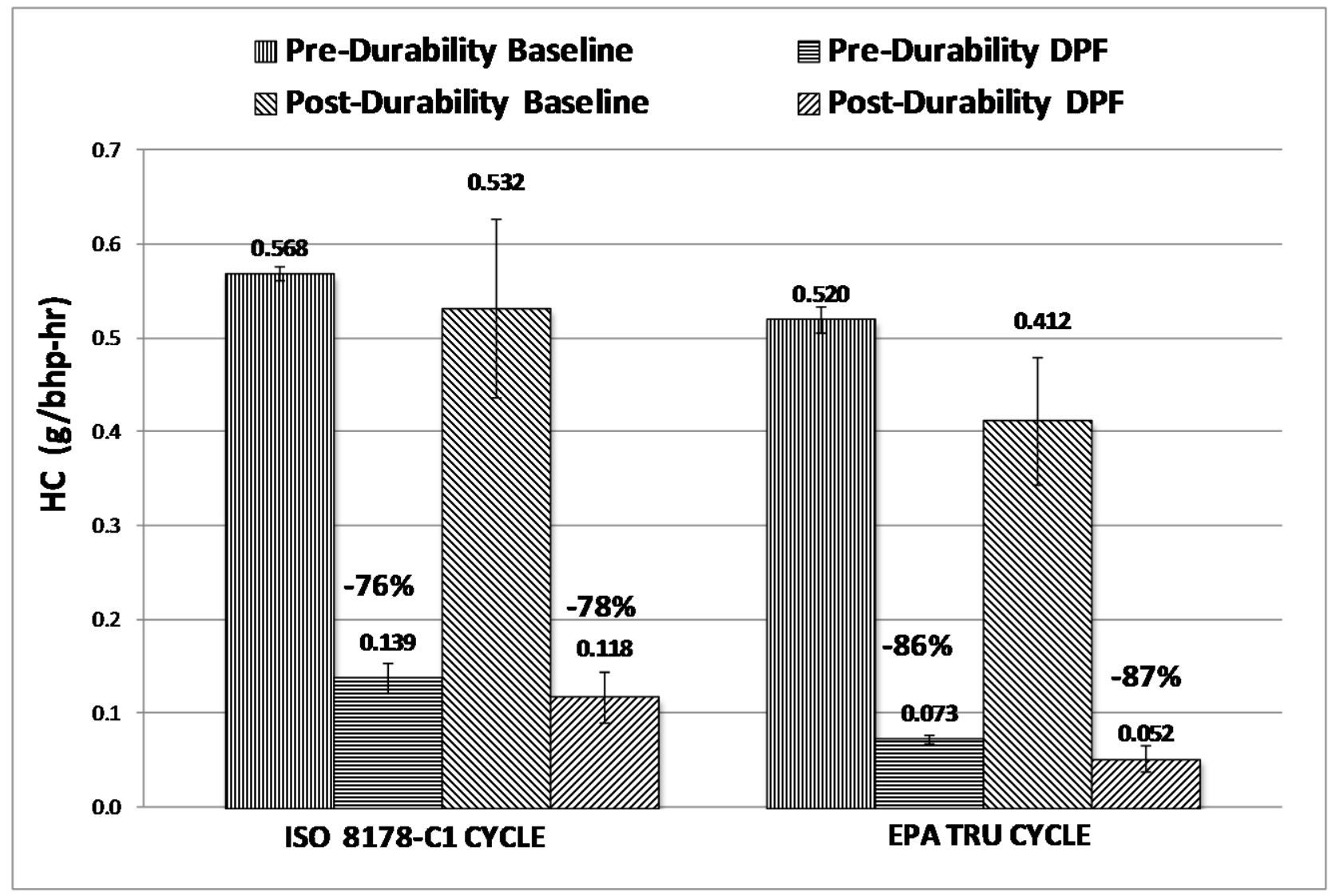

Figure 27: Weighted Brake Specific Hydrocarbons (g/bhp-hr) 


\subsubsection{CO Emission}

$\mathrm{CO}$ results from the emissions testing are shown in Figure 28. Filter system reduced $\mathrm{CO}$ emission by more than $64 \%$ and $77 \%$ over ISO 8178-C1 [2] and EPA TRU [3] test cycle, respectively.

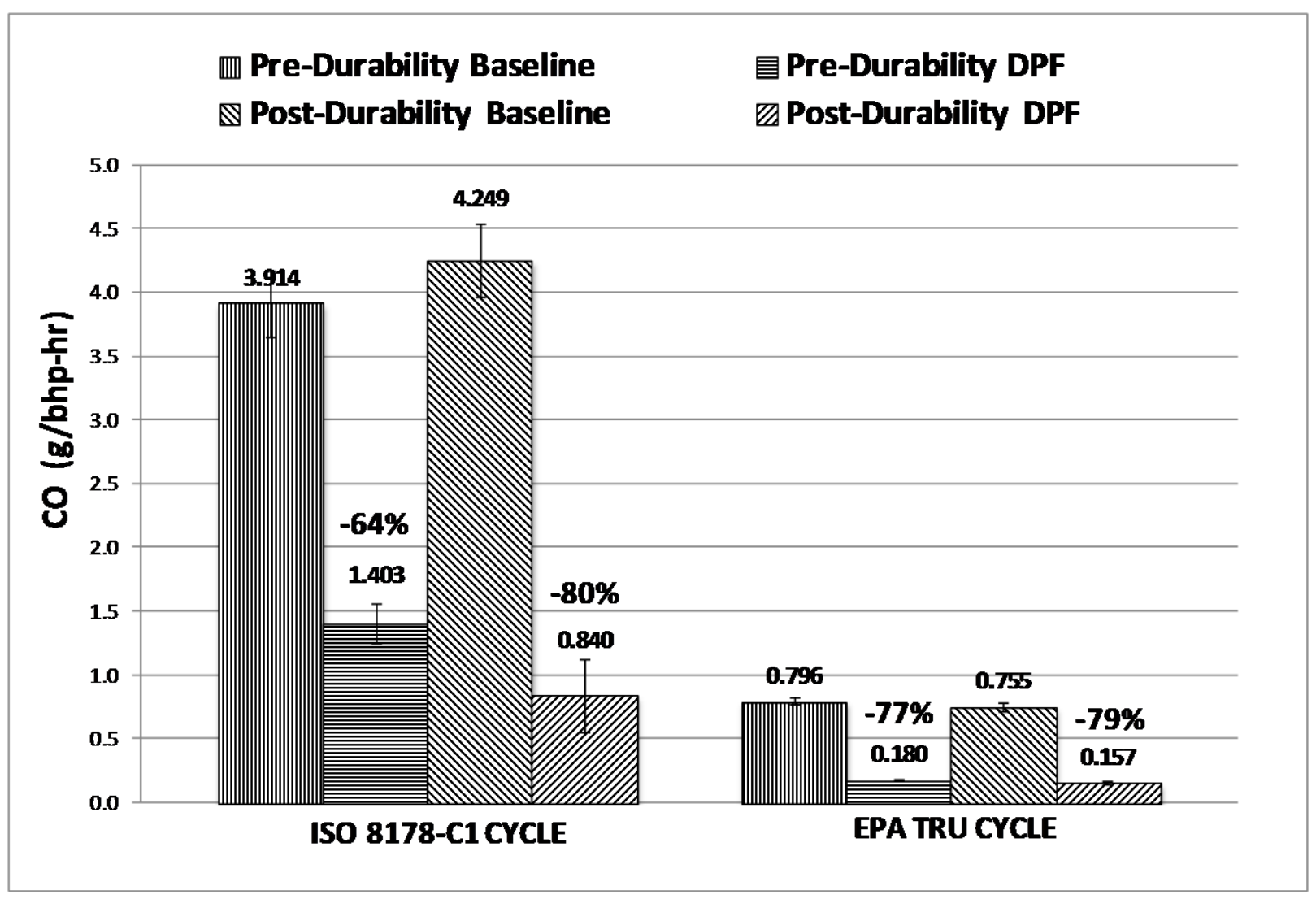

Figure 28: Weighted Brake Specific Carbon Monoxide (g/bhp-hr)

\subsection{4 $\mathrm{NO}_{\mathrm{x}}$ Emission}

As shown in Figure 29, filter system was able to reduce $\mathrm{NO}_{\mathrm{x}}$ emission moderately. $\mathrm{NO}_{\mathrm{x}}$ emissions were reduced by more than $2.4 \%$ and $3.5 \%$ in ISO 8178-C1 [2] and EPA TRU [3] test cycle, respectively. 


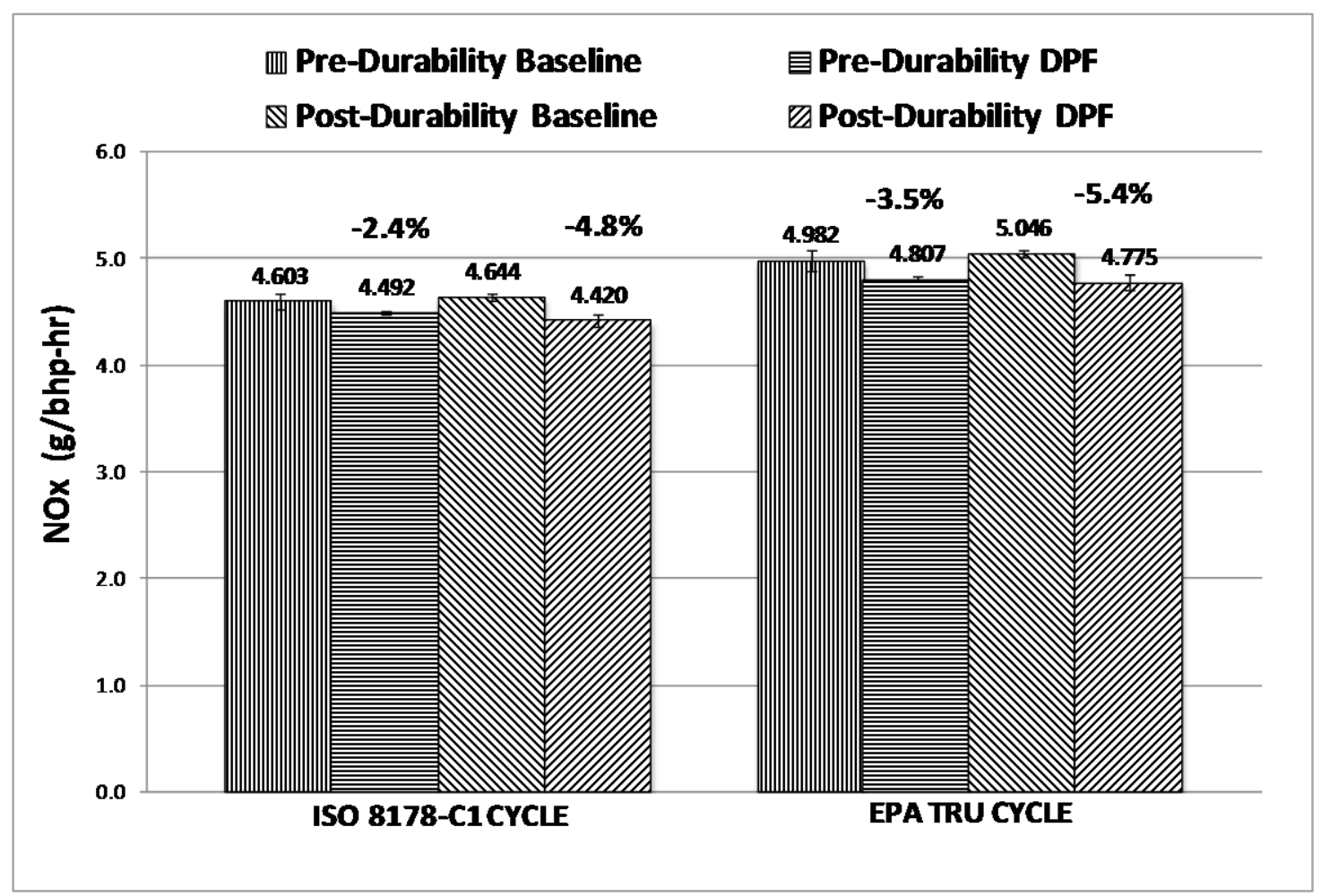

Figure 29: Weighted Brake Specific Nitrogen Oxides (g/bhp-hr)

\subsubsection{NO Emission}

The average results for the NO emission are shown in Figure 30. The filter system reduced NO emissions by more than $6.8 \%$ and $11 \%$ in ISO $8178-\mathrm{C} 1$ [2] and EPA TRU [3] test cycle, respectively.

\subsection{6 $\mathrm{NO}_{2}$ Emission}

The average results for the $\mathrm{NO}_{2}$ emission are shown in Figure 31. It was observed that the $\mathrm{NO}_{2}$ emission for the filter system increased over the baseline testing. When considering the percentage change in $\mathrm{NO}_{2}$ levels, the baseline $\mathrm{NO}_{2}$ levels were low resulting in large percentage increases for relatively small increases in absolute emissions levels. 


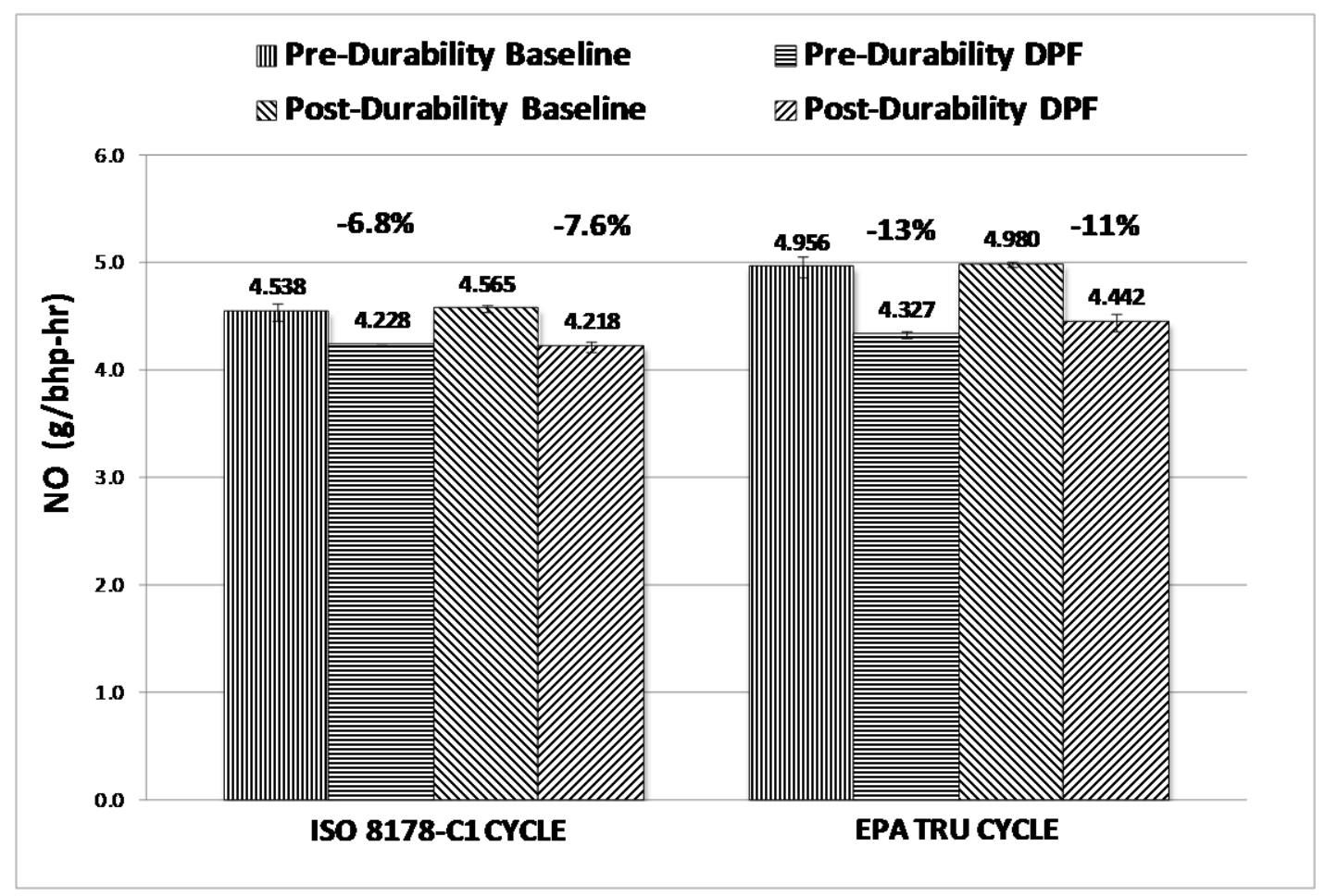

Figure 30: Weighted Brake Specific Nitrogen Monoxide (g/bhp-hr)

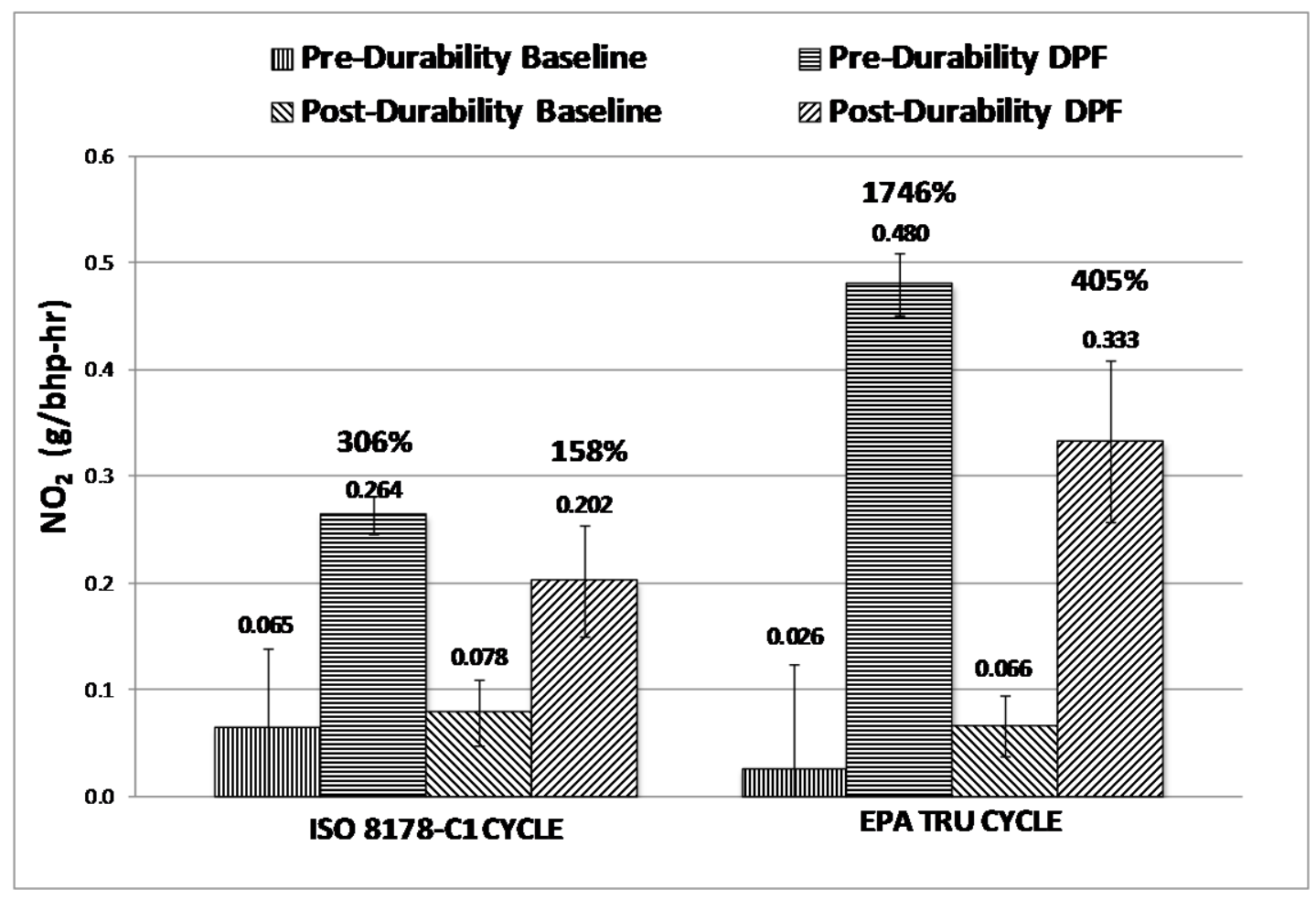

Figure 31: Weighted Brake Specific Nitrogen Dioxide (g/bhp-hr) 


\subsection{7 $\mathrm{CO}_{2}$ Emission}

$\mathrm{CO}_{2}$ results are shown in Figure 32. In pre-durability testing, $\mathrm{CO}_{2}$ emission increased over the baseline due to the pumping losses associated with the increased backpressure. During the postdurability testing, it was observed that both $\mathrm{CO}_{2}$ emissions and fuel consumption decreased slightly during the DPF-out testing. The reason for this abnormal behavior could not be explained. But as discussed earlier, a new batch of test fuel with the same fuel properties was used for post-durability testing which may explain the abnormal behavior.

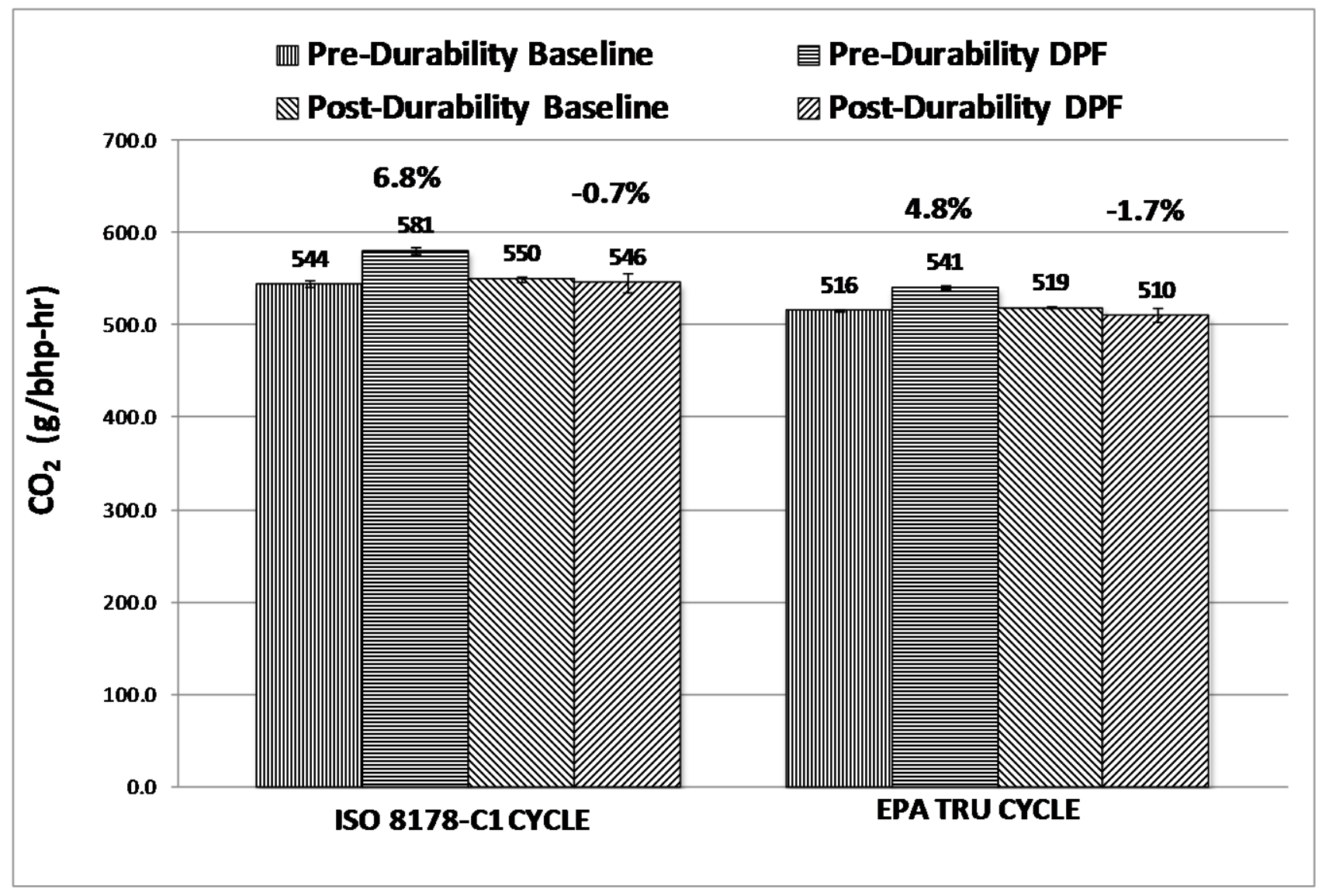

Figure 32: Weighted Brake Specific Carbon Dioxide (g/bhp-hr) 


\subsubsection{Fuel Consumption}

The average bsFC results are shown in Figure 33. Fuel consumption increased over the baseline testing during the pre-durability testing and as discussed earlier a decrease in fuel consumption was observed during the post-durability testing.

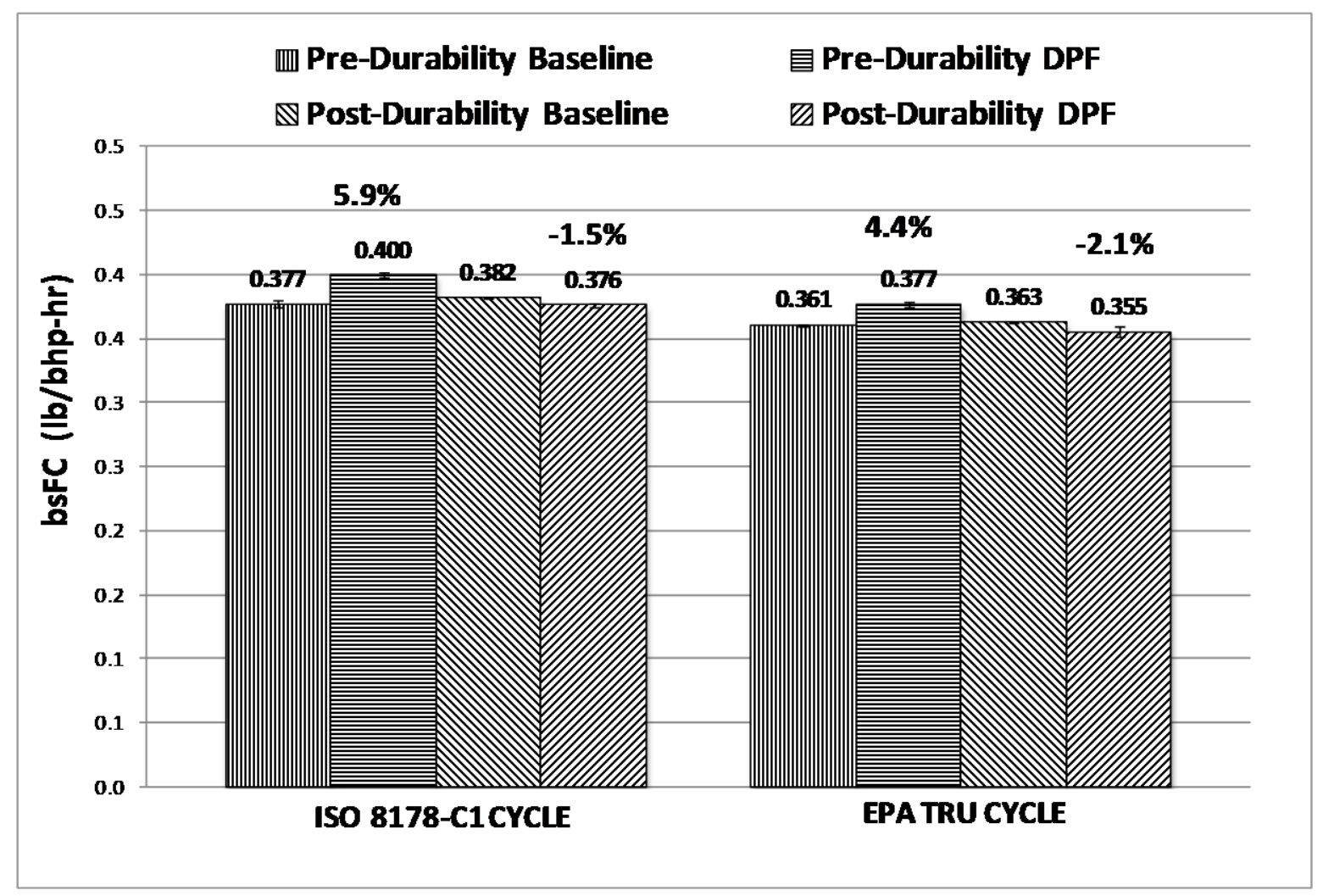

Figure 33: Weighted Brake Specific Fuel Consumption (lb/bhp-hr) 


\subsubsection{Final Emissions Reduction from the Filter System}

The average percentage reduction from the filter system for both pre and post-durability testing for all the emission components is given in Table 29. It was observed that the filter system was able to reduce PM by more than $85 \%$ in both the test cycles as required by the definition of Level 3 VDECS.

Table 29: Final Percentage Emissions Reduction

\begin{tabular}{|c|c|c|}
\hline \multirow{2}{*}{$\begin{array}{c}\text { Emission } \\
\text { Component }\end{array}$} & \multicolumn{2}{|c|}{ Reductions (\%) } \\
\cline { 2 - 3 } & ISO 8178-C1 cycle & $\begin{array}{c}\text { EPA TRU } \\
\text { cycle }\end{array}$ \\
\hline $\mathrm{PM}$ & $96.5 \pm 0.9$ & $92.3 \pm 7.1$ \\
\hline $\mathrm{HC}$ & $76.8 \pm 4.8$ & $86.6 \pm 3.0$ \\
\hline $\mathrm{CO}$ & $72.2 \pm 5.2$ & $78.3 \pm 2.0$ \\
\hline $\mathrm{NO}$ & $3.6 \pm 2.9$ & $4.5 \pm 3.1$ \\
\hline $\mathrm{NO}_{\mathrm{x}}$ & $7.2 \pm 3.1$ & $11.7 \pm 3.4$ \\
\hline $\mathrm{NO}_{2}$ & $-232 \pm 316$ & $-1075 \pm 296$ \\
\hline $\mathrm{CO}_{2}$ & $-3.1 \pm 1.4$ & $-1.6 \pm 0.9$ \\
\hline $\mathrm{bsFC}$ & $-2.2 \pm 0.7$ & $-1.1 \pm 0.8$ \\
\hline
\end{tabular}

\subsubsection{Final Incremental Increase in $\mathrm{NO}_{2}$ Emissions}

The final average incremental increase in $\mathrm{NO}_{2}$ emission for both pre-durability and postdurability testing for ISO 8178-C1 [2] and EPA TRU [3] test cycle is determined by using the equation 18.

Substituting initial and final values in Equation 18, it was concluded that the filter system complied with the maximum allowable increase of $20 \%$ in $\mathrm{NO}_{2}$ levels, as the total increase in $\mathrm{NO}_{2}$ level for pre-durability and post-durability testing was $5.6 \% \pm 2.6 \%$. 


\section{CHAPTER 5}

\section{CONCLUSIONS}

In order to verify the particulate filter system as a Level 3 VDECS, all the regulated emissions were measured and documented; first with a new DPF (pre-durability) and then with the same DPF aged for 1,000 hours (post-durability testing).

In pre-durability emissions testing, the particulate filter system was observed to reduce PM emissions by at least $98 \%$, HC emissions by $75 \%$ and CO emissions by $64 \%$. A slight decrease in $\mathrm{NO}_{\mathrm{x}}$ emissions $\left(<4 \%\right.$ ) was observed which might be a result of conversion of $\mathrm{NO}_{2}$ to $\mathrm{N}_{2}$ over the catalyzed filter. The initial $\mathrm{NO}_{2}$ compliance value (average of both test cycles) was $6.71 \% \pm$ $1.60 \%$ of total $\mathrm{NO}_{\mathrm{x}}$, which satisfied the maximum permissible limit of $20 \%$ for verification. Both $\mathrm{CO}_{2}$ emissions and fuel consumption increased by $6 \%$ due to increased exhaust back pressure.

For post-durability testing, a new batch of similar fuel with the same properties was procured for prolonged emissions testing, although a few emission tests were still conducted with the original fuel. The emissions testing results with the new fuel showed a PM reduction of $95.7 \%$ when tested using the original test fuel and $94.8 \%$ with the new batch of test fuel. $\mathrm{NO}_{2}$ compliance value increased $3.25 \% \pm 5.53 \%$ over the baseline engine-out levels. $\mathrm{HC}$ and $\mathrm{CO}$ emissions were reduced by at least $78 \%$ and $79 \%$, respectively. These results qualify the DiSiC particulate filter system as a Level 3 VDECS.

Conventional uniformly coated filters often show very high levels of $\mathrm{NO}_{2}$ after the filter and with high PGM loadings it becomes increasingly difficult to provide cost effective solutions. The passive regenerating technology does have some draw backs when it comes to dependence on temperature profiles in the exhaust during normal operation. The passive approach will not be able to cover the whole population of TRUs and will have difficulties coping with old (1996 or older model engines) and badly maintained (fuel and oil) engines because of the low exhaust temperature profiles. The passive strategy does offer an attractive solution for the operators as the cost and complexity is advantageous compared to other technologies such as active regeneration. 
Diesel particulate filters are very sensitive to exhaust gas temperatures and fuel sulfur content. The particulate filter system verified in this study failed during the in-field applications. It was reported that the filter system clogged because the exhaust gas temperatures from the in-field engines did not meet the requirements for regeneration. It is recommended that certain vehicle applications be equipped with data loggers to continuously monitor exhaust back pressure and temperature. When sufficient exhaust gas temperatures for filter regeneration are achieved, the monitoring can be stopped. Also, CARB should include exhaust gas temperature requirements for the DPF to regenerate sufficiently in future regulations. 


\section{REFERENCES}

1. California Code of Regulations, Title 13, Division 3, Chapter 14, "Verification Procedure, Warranty and In-Use Compliance Requirements for In-Use Strategies to Control Emissions from Diesel Engines” Sections 2700 - 2710, accessed 17-July 2007

2. International Standard ISO 8178-4, Reciprocating Internal Combustion Engines - Exhaust Emission Measurement, International Organization for Standardization, Reference No. ISO 8178-4: 1996(E), accessed 15-Aug 2007

3. Code of Federal Regulations, Title 40 Protection of Environment, Section 1039.645, US Government Printing Office, 2006

4. C.V. Kulkarni, H. A. Dwyer, "Modeling and Performance of Trailer Refrigeration Units with Alternative Power Systems", SAE paper No. 2007-01-0764, SAE International, Warrendale, PA, 2007

5. State of California, Air Resources Board, California Exhaust Emissions Standards and Test Procedures for New 2000 and Later Off-Road Compression-Ignition Engines, Part 1-B, http://www.arb.ca.gov/regact/ciengine/att1b.pdf, accessed 20-Nov 2006

6. Code of Federal Regulations, Title 40 Protection of Environment, Part 89, US Government Printing Office, 2006

7. California Code of Regulations, Title 13, Division 3, Chapter 9, Article 8: Off-Road Airborne Toxic Control Measures, Section 2477: “Airborne Toxic Control Measures for In-Use Diesel-Fueled Transport Refrigeration Units (TRU) and TRU Generator Sets, and Facilities where TRUs Operate”, accessed 08-July 2007

8. "Electric-Powered Trailer Refrigeration Unit Market Study And Technology Assessment", Shurepower, accessed 23-Feb 2010, see also http://www.shorepower.com/ElectricPoweredTrailerRefrigeration.pdf 
9. "How Do I Comply with the TRU ATCM for Operators of TRUs and TRU Generator Sets, and Facilities Where TRUs Operate?" [Sacramento, CA]: California Environmental Protection Agency, Air Resources Board, 2008

10. R.A. Barnitt, D. Chernich, M. Burnitzki, A. Oshinuga, M. Miyasato, E. Lucht, D.V.D. Merwe, P. Schaberg, "Emissions of Transport Refrigeration Units with CARB Diesel, Gas-to Liquid Diesel and Emissions Control Devices," SAE Paper No. 2009-01-2722, SAE International, Warrendale, PA, 2009

11. T.L. Alleman, R.A. Barnitt, L.R. Eudy, M. Miyasato, A. Oshinuga, T.P. Corcoran, S. Chatterjee, T. Jacobs, R.A. Cherrillo, N.N. Clark, S.W. Wayne, "Final Operability and Chassis Emissions Results From a Fleet of Class 6 Trucks Operating on Gas-To-Liquid Fuel and Catalyzed Diesel Particle Filters," SAE Paper No. 2005-01-3769, SAE International, Warrendale, PA, 2005

12. T.L. Alleman, R.L. McCormick, "Fischer-Tropsch Diesel Fuels - Properties and Exhaust Emissions: a Literature Review," SAE Paper No. 2003-01-0763, SAE International, Warrendale, PA, 2003

13. C.V. Kulkarni, H. A. Dwyer, "Modeling and Performance of Trailer Refrigeration Units with Alternative Power Systems," SAE paper No. 2007-01-0764, SAE International, Warrendale, PA, 2007

14. SmartWay Transportation Partnership. (2004). Idle Free Corridors: Implementation Meeting. accessed 03-February, 2010, see also http://epa.gov/smartway/presentations/background.pdf

15. DOE Hydrogen Program Home Page. accessed 03-February, 2010, see also http://www.hydrogen.energy.gov/pdfs/review05/fcp_32_brodrick.pdf

16. J. Kramer, U. Pfahi, C. Bruestle, R. Diewald, G. Hunter, "The PM-Metalit: A PM control technology for Tier 4 Off-Highway Applications," SAE Paper No. 2009-01-2838, SAE International, Warrendale, PA, 2009 
17. T. Gardner, A. Yetkin, R. Shotwell, A. Kotrba, H. Gysling, Z. Mustafa, J. Holroyd, "Evaluation of a DPF Regeneration System and DOC Performance Using Secondary Fuel Injection,” SAE Paper No. 2009-01-2884, SAE International, Warrendale, PA, 2009

18. D.H. Lee, K.T. Kim, M.S. Cha, J.O. Lee, Y.H. Song, H. Cho, Y.S. Kim, Y. Song, T. Jee, “Active Regenerative DPF Using a Plasma Assisted Burner," SAE Paper No. 2009-01-1926, SAE International, Warrendale, PA, 2009

19. U.S. Department of Energy, Diesel Emission Control-Sulfur Effects Projects Summary, accessed 21-February 2010.

20. H. Tschoke, Lothar Schulze, Gunter Braungarten. Study of Diesel Engine Equipped with After Treatment Systems, accessed 15-March 2010.

21. A.L. Boehman, J. Song, and M. Alam, "Impact of Biodiesel Blending on Diesel Soot and the Regeneration of Particulate Filters" The Energy Institute, The Pennsylvania State University, 2005

22. K. Vertin, S. He, A. Heibel, "Impacts of B20 Biodiesel on Cordierite Diesel Particulate Filter Performance,” SAE Paper No. 2009-01-2736, SAE International, Warrendale, PA, 2009

23. Advanced Clean Energy Technologies: Diesel Emission Control Options. [Wayne, Pa.]: Environex, 1997

24. Thermal $\mathrm{NO}_{\mathrm{x}}$ Formation, Fluent Incorporated, accessed 15-March 2010, see also http://jullio.pe.kr/fluent6.1/help/html/ug/node624.htm

25. Y. Kitamura, A. Mohammadi, T. Ishiyama, M. Shioji, "Fundamental Investigation of NOx Formation in Diesel Combustion Under Supercharged and EGR Conditions," SAE Paper No. 2005-01-0364, SAE International, Warrendale, PA, 2005

26. P.L. Burk, J.K. Hochmuth, D.R. Anderson, S. Sung, S.J. Tauster, C.O. Tolentino, J. Rogalo, G. Miles, M. Niejako, A. Punke, and U. Dahle, "Cold start hydrocarbon emissions control," SAE Paper No. 950410, SAE International, Warrendale, PA, 1995 
27. B. Challen and R. Baranescu, Diesel Engine Reference Book, II edition, Society of Automotive Engineers, 1999

28. B.J. Andrew, “Particulate Matter Regulation and Implications for the Diesel Engine," SAE Paper No. 981174, SAE International, Warrendale, PA, 1998

29. K. J. Baumgard and J. J. Johnson, "The effect of fuel and engine design on diesel exhaust particle size distributions," SAE Paper No. 960131, SAE International, Warrendale, PA, 1996

30. H. Burtscher, "Literature Study: Tailpipe particulate emission measurement for diesel engines," Fachhochschule Aargau, University of Applied Science, Switzerland,2001

31. D. Kittelson, J. Johnson, W. Watts, Q. Wei, M. Drayton, D. Paulsen, and N. Bukowiecki, "Diesel Aerosol Sampling in the atmosphere," SAE Paper No. 2000-01-2212, SAE International, Warrendale, PA, 2000

32. "Understanding the health effects of components of the particulate matter mix: Progess and next steps," Helath Effects Institute, accessed 12-April 2010

33. W. K. C. Morgan, R. B. Reger, and D. M. Tucker, "Health effects of diesel," Ann. occup. Hyg., vol. 41, no. 6, pp. 643-658, 1997

34. C.C. Lin, S.-J. Chen, K.-L. Huang, W.-I. Hwang, G.-P. Chang-Chien, and W.-Y. Lin, "Characteristics of of Metals in Nano/Ultrafine/Fine/Coarse Particles Collected Beside a Heavily Trafficked Road," Environmental Science and Technology, vol. 39, no. 21, pp. 81138122,2005

35. S. Ichikawa, Y. Uchida, A. Otsuka, T. Harada, T. Hamanaka, K. Nagashima, M. Nagata, “Material development of High Porous SiC for Catalysed Diesel Particulate Filters," SAE Paper No. 2003- 01-0380, SAE International, Warrendale, PA, 2003

36. K. Ogya, A. Kudo, Y. Oshimi, H. Sato, K. Ohno, "Characterisation of Thin Wall SiC-DPF," SAE Paper No. 2003-01-0377, SAE International, Warrendale, PA, 2003 
37. N. Miyakawa, H. Maeno, H. Takahashi, "Characteristics and Evaluation of Porous Silicon Nitride DPF,” SAE Paper No. 2003-01-0386, SAE International, Warrendale, PA, 2003

38. Dipex and DiSiC Installation Guide, Dinex A/s, accessed 15-February 2010 http://www.dinexexhausts.com/data/attachments/26874BD0-1BA9-4FA4-A7BC602BCCBEAB53/9C5F97C2-6F9D-4BD1-9E12-B7F9AEFD5A17.pdf

39. "Particulate Reduction Technologies for Transport Refrigeration Units", Dinex Emission Technology A/S; Dinex Exhaust Inc.

40. CARB Verification of Dinex Aftertreatment System for Transportation Refrigeration Units, submitted by West Virginia University, P.O. Box 6106 Morgantown, WV 26506-6106, accessed 05-January, 2009

41. Code of Federal Regulations, Title 40 Protection of Environment, Part 86, US Government Printing Office, 2006

42. Code of Federal Regulations, Title 40 Protection of Environment, Part 92, US Government Printing Office, 2006

43. Code of Federal Regulations, Title 30 Mining Resources, Part 7, US Government Printing Office, 2006

44. Reschke, G.D., "Optimization of a Flame Ionization Detector for Determination of Hydrocarbon in Diluted Automotive Exhausts," SAE Paper No. 770141, SAE International, Warrendale, PA, 1977

45. CAI, Model 600 - NDIR Users manual, accessed 21-April 2010, see also http://www.gasanalyzers.com/onlinedocs/600_NDIR/600_NDIR_Manual_upto_U06080.pdf.

46. Directive 1999/96/EC of the European Parliament and of the Council, pages 58-156, 1999, see also http://www.dieselnet.com/tech/text/dir_1999_96_ec.pdf 
47. California Code of Regulations, Title 13, Division 3, Chapter 14, Verification Procedure, Warranty and In-Use Compliance Requirements for In-Use Strategies to Control Emissions from Diesel Engines," Sections 2700 - 2710

48. Moore, David S., and George P. McCabe. Introduction to the Practice of Statistics. New York: W.H. Freeman and, 2006

49. California Code of Federal Regulations, Title 13, Division 3, Chapter 5, Standards for Motor Vehicle Fuels, Article 2, Standards for Diesel Fuel, Sections 2280-2283, http://www.arb.ca.gov/fuels/diesel/081404dslregs.pdf, accessed 20-Nov 2006 


\section{APPENDICES}




\section{APPENDIX A}

\section{LABORATORY EQUIPMENT USED}

This appendix describes the equipment and instruments that were used during this study. All the required testing was performed at the West Virginia University Engines and Emissions Research Laboratory (WVU EERL). The engine testing equipment and emissions sampling and measurement systems in the WVU EERL were designed in accordance to the specifications outlined in the Code of Federal Regulations Title 40, Part 89. The equipments used is given in Table 30.

Table 30: Equipment Used

\begin{tabular}{|c|c|c|c|c|}
\hline Description & Function & Use & Model & Range \\
\hline $\begin{array}{l}\text { Intake Air Flow } \\
\text { LFE }\end{array}$ & $\begin{array}{l}\text { Used as a QA } \\
\text { means to monitor } \\
\text { intake air flow }\end{array}$ & QA & $\begin{array}{l}\text { Meriam } \\
\text { 50MC2-2 }\end{array}$ & $\begin{array}{l}0-99.3 \\
\text { scfm }\end{array}$ \\
\hline $\begin{array}{l}\text { LFE } \\
\text { Temperature }\end{array}$ & $\begin{array}{l}\text { Measure the air } \\
\text { temperature at the } \\
\text { inlet to the LFE }\end{array}$ & QA & RTD & $0-600{ }^{\circ} \mathrm{C}$ \\
\hline Intake Dewpoint & $\begin{array}{l}\text { Independent } \\
\text { measurement of } \\
\text { intake humidity } \\
\text { level for NOx } \\
\text { correction }\end{array}$ & $\begin{array}{l}\text { QA and as a Backup } \\
\text { for the Omega } \\
\text { HX52D }\end{array}$ & $\begin{array}{l}\text { General Eastern } \\
\text { Dew-10 }\end{array}$ & $-40-58{ }^{\circ} \mathrm{C}$ \\
\hline $\begin{array}{l}\text { Fuel } \\
\text { Temperature }\end{array}$ & $\begin{array}{l}\text { Measure the fuel } \\
\text { temperature } \\
\text { entering the engine }\end{array}$ & 40CFR86 Required & $\begin{array}{l}\text { Omega J Type } \\
\text { Thermocouple }\end{array}$ & $0-500{ }^{\circ} \mathrm{C}$ \\
\hline $\begin{array}{l}\text { Engine Oil } \\
\text { Temperature }\end{array}$ & $\begin{array}{l}\text { Measure the engine } \\
\text { oil temperature }\end{array}$ & Engine Setup and QA & $\begin{array}{l}\text { Omega J Type } \\
\text { Thermocouple }\end{array}$ & $0-500{ }^{\circ} \mathrm{C}$ \\
\hline $\begin{array}{l}\text { Engine Coolant } \\
\text { Temperature }\end{array}$ & $\begin{array}{l}\text { Measure the engine } \\
\text { coolant }\end{array}$ & Engine Setup and QA & $\begin{array}{l}\text { Omega J Type } \\
\text { Thermocouple }\end{array}$ & $0-500{ }^{\circ} \mathrm{C}$ \\
\hline
\end{tabular}




\begin{tabular}{|c|c|c|c|c|}
\hline & temperature & & & \\
\hline $\begin{array}{l}\text { Dynamometer } \\
\text { Load Cell }\end{array}$ & Measure the torque & $\begin{array}{l}\text { Required for feedback } \\
\text { control of the throttle } \\
\text { and used for the } \\
\text { regression analysis } \\
\text { and to calculate work } \\
\text { per 40CFR86 }\end{array}$ & $\begin{array}{l}\text { Interface SSM- } \\
\text { AJ-250 }\end{array}$ & $0-250 \mathrm{lb}$ \\
\hline $\begin{array}{l}\text { Dynamometer/ } \\
\text { Engine Speed }\end{array}$ & $\begin{array}{l}\text { Measure the shaft } \\
\text { speed }\end{array}$ & $\begin{array}{l}\text { Required for the } \\
\text { regression analysis } \\
\text { and to calculate work } \\
\text { per 40CFR86 }\end{array}$ & $\begin{array}{l}\text { Accu-coder } \\
\text { 225A-34-0080- } \\
\text { PQ-F-N-T }\end{array}$ & 0-3000 rpm \\
\hline $\begin{array}{l}\text { Sampling Plane } \\
\text { Temperature }\end{array}$ & $\begin{array}{l}\text { Measure the dilute } \\
\text { exhaust } \\
\text { temperature in the } \\
\text { dilution tunnel at } \\
\text { the sampling plane }\end{array}$ & QA & $\begin{array}{l}\text { Omega J Type } \\
\text { Thermocouple }\end{array}$ & $0-500{ }^{\circ} \mathrm{C}$ \\
\hline $\begin{array}{l}\text { Heated Sample } \\
\text { System } \\
\text { Temperature }\end{array}$ & $\begin{array}{l}\text { Record each of the } \\
\text { heated components } \\
\text { in the gaseous } \\
\text { sample system }\end{array}$ & $\begin{array}{l}40 \text { CFR86 } \\
\text { Requirements }\end{array}$ & $\begin{array}{l}\text { Omega } \mathrm{J} \text { and } \mathrm{K} \\
\text { Type } \\
\text { Thermocouple }\end{array}$ & NA \\
\hline $\begin{array}{l}\text { TPM Filter Face } \\
\text { Temperature }\end{array}$ & $\begin{array}{l}\text { Measure the filter } \\
\text { face temperature }\end{array}$ & 40CFR86 Required & $\begin{array}{l}\text { Omega J Type } \\
\text { Thermocouple }\end{array}$ & $0-500{ }^{\circ} \mathrm{C}$ \\
\hline TPM Flow & $\begin{array}{l}\text { Measure the } \\
\text { flowrate through } \\
\text { the secondary } \\
\text { dilution tunnel }\end{array}$ & $\begin{array}{l}\text { TPM Emission } \\
\text { Calculations } \\
\text { 40CFR86 Required }\end{array}$ & $\begin{array}{l}\text { C100M-RD-3- } \\
\text { OV1-SV1-PV2- } \\
\text { V1-S0-CO }\end{array}$ & $0-7 \mathrm{scfm}$ \\
\hline $\begin{array}{l}\text { THC } \\
\text { Concentration }\end{array}$ & $\begin{array}{l}\text { Measure the } \\
\text { concentration of } \\
\text { the THC in the } \\
\text { dilution tunnel }\end{array}$ & $\begin{array}{l}\text { THC Emission } \\
\text { Calculation } \\
\text { 40CFR86 Required }\end{array}$ & Horiba FIA-236 & $\begin{array}{l}\text { Selectable } \\
\text { From } 1 \text { to } \\
5,000 \mathrm{ppm}\end{array}$ \\
\hline High & Measure & Emission & Horiba AIA-210 & Selectable \\
\hline
\end{tabular}




\begin{tabular}{|c|c|c|c|c|}
\hline Concentration & $\begin{array}{l}\text { concentration of } \\
\text { the } \mathrm{CO} \text { in the } \\
\text { dilution tunnel, } \\
\text { high range } \\
\text { analyzer }\end{array}$ & $\begin{array}{l}\text { Calculation } \\
\text { 40CFR86 Required }\end{array}$ & & $\begin{array}{l}\text { From } 250 \text { to } \\
3000 \mathrm{ppm}\end{array}$ \\
\hline $\begin{array}{l}\mathrm{CO}_{2} \\
\text { Concentration }\end{array}$ & $\begin{array}{l}\text { Measure the } \\
\text { concentration of } \\
\text { the } \mathrm{CO} 2 \text { in the } \\
\text { dilution tunnel }\end{array}$ & $\begin{array}{l}\text { Used in Calculations - } \\
\text { 40CFR86 Option }\end{array}$ & Horiba AIA-210 & $\begin{array}{l}\text { Selectable } \\
\text { From } 1 \text { to } \\
12 \%\end{array}$ \\
\hline $\begin{array}{l}\text { NOx } \\
\text { Concentration }\end{array}$ & $\begin{array}{l}\text { Measure the } \\
\text { concentration of } \\
\text { the NOx in the } \\
\text { dilution tunnel }\end{array}$ & $\begin{array}{l}\text { NOx } \\
\text { Calculation } \\
\text { 40CFR86 Required }\end{array}$ & Rosemount 955 & $\begin{array}{l}\text { Selectable } \\
\text { From } 10 \text { to } \\
10,000 \mathrm{ppm}\end{array}$ \\
\hline $\begin{array}{l}\mathrm{NO} \\
\text { Concentration }\end{array}$ & $\begin{array}{l}\text { Measure the } \\
\text { concentration of } \\
\text { the NO in the } \\
\text { dilution tunnel }\end{array}$ & $\begin{array}{l}\text { Secondary NO } \\
\text { Emission Calculation } \\
\text { - QA and backup to } \\
\text { primary NOx analyzer }\end{array}$ & CAI HCLD-C & $\begin{array}{l}\text { Selectable } \\
\text { From } 5 \text { to } \\
5000 \mathrm{ppm}\end{array}$ \\
\hline $\begin{array}{l}\text { Gaseous } \\
\text { Emissions } \\
\text { Sample System }\end{array}$ & $\begin{array}{l}\text { Provide the } \\
\text { required sample } \\
\text { conditioning for } \\
\text { the gaseous } \\
\text { emissions } \\
\text { analyzers }\end{array}$ & 40CFR86 Required & Tess-com & NA \\
\hline Gas Divider & $\begin{array}{l}\text { Used to blend a } \\
\text { calibration gas } \\
\text { with a zero gas for } \\
\text { calibrating } \\
\text { emission analyzers }\end{array}$ & 40CFR86 Required & $\begin{array}{l}\text { STEC SGD- } \\
710 \mathrm{C}\end{array}$ & $\begin{array}{l}0-100 \%, \\
\text { steps } \\
10 \%\end{array}$ \\
\hline Microbalance & $\begin{array}{l}\text { Used to measure } \\
\text { TPM filters }\end{array}$ & 40CFR86 Required & Sartorius SE2-F & $2100 \mathrm{mg}$ \\
\hline
\end{tabular}




\section{APPENDIX B}

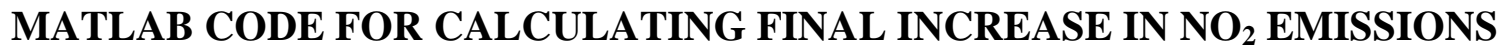

> syms a b c d

> syms A B C D

$>\mathrm{x}=(\mathrm{a}+\mathrm{b}-2 * \mathrm{c}) /(4 * \mathrm{~d})+(\mathrm{A}+\mathrm{B}-2 * \mathrm{C}) /(4 * \mathrm{D})$

$\mathrm{x}=\left(\mathrm{a}+\mathrm{b}-2^{*} \mathrm{c}\right) /\left(4^{*} \mathrm{~d}\right)+\left(\mathrm{A}+\mathrm{B}-2^{*} \mathrm{C}\right) /(4 * \mathrm{D})$

where,

$\mathrm{x}$ - incremental increase in $\mathrm{NO}_{2}$ emissions

a and A - pre-durability test $\mathrm{NO}_{2}$ emission results for ISO 8178-C1 and EPA TRU test cycle

$\mathrm{b}$ and $\mathrm{B}$ - post-durability test $\mathrm{NO}_{2}$ emission results for ISO 8178-C1 and EPA TRU test cycle

c and $\mathrm{C}$ - baseline test $\mathrm{NO}_{2}$ emission results for ISO 8178-C1 and EPA TRU test cycle

$\mathrm{d}$ and $\mathrm{D}$ - baseline test $\mathrm{NO}_{\mathrm{x}}$ emission results for ISO 8178-C1 and EPA TRU test cycle

$>\mathrm{dx}=$

$\left(\left(\operatorname{diff}(\mathrm{x}, \mathrm{a})^{*} \mathrm{da}\right)^{\wedge} 2+\left(\operatorname{diff}(\mathrm{x}, \mathrm{b})^{*} \mathrm{db}\right)^{\wedge} 2+\left(\operatorname{diff}(\mathrm{x}, \mathrm{c})^{*} \mathrm{dc}\right)^{\wedge} 2+\left(\operatorname{diff}(\mathrm{x}, \mathrm{d})^{*} \mathrm{dd}\right)^{\wedge} 2+\left(\operatorname{diff}(\mathrm{x}, \mathrm{A})^{*} \mathrm{dA}\right)^{\wedge} 2+(\operatorname{diff}(\mathrm{x}\right.$, $\left.\left.\mathrm{B})^{*} \mathrm{~dB}\right)^{\wedge} 2+\left(\operatorname{diff}(\mathrm{x}, \mathrm{C})^{*} \mathrm{dC}\right)^{\wedge} 2+\left(\operatorname{diff}(\mathrm{x}, \mathrm{D})^{*} \mathrm{dD}\right)^{\wedge} 2\right)^{\wedge} 0.5$

$\mathrm{dx}=\left(\mathrm{dA}^{\wedge} 2 /\left(16^{*} \mathrm{D}^{\wedge} 2\right)+\mathrm{dB}^{\wedge} 2 /\left(16^{*} \mathrm{D}^{\wedge} 2\right)+\mathrm{dC}^{\wedge} 2 /\left(4^{*} \mathrm{D}^{\wedge} 2\right)+\mathrm{da}^{\wedge} 2 /\left(16^{*} \mathrm{~d}^{\wedge} 2\right)+\mathrm{db}^{\wedge} 2 /\left(16^{*} \mathrm{~d}^{\wedge} 2\right)+\right.$ $\left.\mathrm{dc}^{\wedge} 2 /\left(4 * \mathrm{~d}^{\wedge} 2\right)+\left(\mathrm{dd}^{\wedge} 2 *\left(\mathrm{a}+\mathrm{b}-2^{*} \mathrm{c}\right)^{\wedge} 2\right) /\left(16^{*} \mathrm{~d}^{\wedge} 4\right)+\left(\mathrm{dD}^{\wedge} 2^{*}\left(\mathrm{~A}+\mathrm{B}-2^{*} \mathrm{C}\right)^{\wedge} 2\right) /\left(16^{*} \mathrm{D}^{\wedge} 4\right)\right)^{\wedge}(1 / 2)$

$>\mathrm{a}=0.264 ; \mathrm{da}=0.017 ; \mathrm{b}=0.202 ; \mathrm{db}=0.254 ; \mathrm{c}=0.065 ; \mathrm{dc}=0.100 ; \mathrm{d}=4.603 ; \mathrm{dd}=0.055 ; \mathrm{A}=0.479$; $\mathrm{dA}=0.030 ; \mathrm{B}=0.333 ; \mathrm{dB}=0.302 ; \mathrm{C}=0.026 ; \mathrm{dC}=0.111 ; \mathrm{D}=4.982 ; \mathrm{dD}=0.083 ; \mathrm{dD}=0.0830$

$>\operatorname{subs}(\mathrm{x})$

ans $=0.0564$

$>\operatorname{subs}(\mathrm{dx})$

ans $=0.0258$

John $\mathrm{H}$.

Hagen

Digitally signed by John H. Hagen 